\title{
LAS LETRAS EN EL ÁRBOL (DE TEÓCRITO A NICOLÁS OLIVARI)
}

\author{
A mis maestros del vigjo Instituto \\ de Filología de Buenos Aires, \\ estos apuntes de literatura argentina comparada, \\ comenzados en aquel tiempo mejor.
}

"Escribo: luego existo", . Esta variación poco metódica de un pensamiento filosófico ilustre, y que parecería en principio reservada al plumífero profesional o confesional ("mon semblable, mon frère..."), parece hoy estar con las manos de la masa, gracias a los nuevos medios de masa materiales - colores más o menos acrílicos, tintas menos o más fluorescentes, rotuladores del más grueso grosor, imbatibles bolígrafos . . Pero (más que "escribo") debería rotularse "impresiono", en su más confesada ambigüedad: las últimas camadas ejercitan colectivamente unos alfabetos tenebrosos, híbridos de jeroglífico y monograma, prácticamente ilegibles para los no iniciados (entre los que mi fortuna me circunscribe), y que reemplazan sin mejorarlas las quizá aljamías que hasta ayer despertaban delicadas nostalgias alhambristas en los usufructuarios del metro parisiense.

En un artículo en el que señala que la denominación de esta práctica - "pintada" - ha alcanzado la consagración académica, Julián Marías subraya con sostenidos ejemplos su carácter primordialmente político y social ${ }^{1}$. Omite - puede sospecharse que de manera muy deliberadamente delicada- el toque opuesto, esencialmente personal, propio de ciertas inscripciones que pueden decirse (en sus más amplios sentires) privadas. Entre los materiales de su "Cancionero popular porteño" el poeta Eduardo

* Como caso excepcional y debido a su extensión, las notas aparecen al final del artículo. 
Jorge Bosco, de amistosa memoria, reservó una sección para los "Versos de letrina y otros obscenos"; al editarse póstumamente sus obras se pensó confiarlos a un cuadernillo aislado que suplementaría unos pocos ejemplares reservados, pero el impresor, atento a las dificultades del momento político, juzgó más prudente no componerlos: y es lástima, pues los había con picante gracejo. (Conozco una compilación algo semejante, bien que prosaica, algunos de cuyos textos, por su extensión y carácter desusadamente confesional, suscitan serias dudas sobre su autenticidad) ${ }^{2}$.

Entre sus dos extremos - socio-persuasivo y escatológico- y antes de la endemia de grafitómanos que nos es dado contemplar, y en la que el embadurnamiento prevalece sobre la comunicación (sus adeptos se ensañan particularmente, en los transportes en común, contra mapas e itinerarios), lo usual eran los cortos mensajes utilitarios y las exhalaciones sentimentales, ya difamatorias o ya encarecedoras, como "los añejos vítores esfumados" que el:joven García Lorca lee todavía en los muros de la "ciudad perdida" de Baeza ${ }^{3}$. Las artísticas ruinas de un parque francés ofrecen a sus contempladores muestras de ambas categorías:

Des grottes, des éboulis à travers lesquels un escalier en colimaçon jette sur les murs qui le bordent, une volée de graffiti: "À Suzanne pour la vie" ou "En souvenir de la troisième marche..." ou bien "Rendez-vous ici, demain soir, à minuit, 15 juin". La pierre fraîche garde ainsi, sous un puzzle de mots qu'avec un brin d'imagination on n'a aucune peine à entourer d'images, quelques traces de baisers, d'attentes, d'heures exquises, de serments éternels, d'étreintes ${ }^{4}$.

La ocupación puede también ser mucho menos inocente:

La vi cuando yo mismo me preparaba a descender [en el interior de la estatua de la Libertad]. Se divertía escribiendo sus iniciales en el hueco de la ventana. No tenía importancia: montones de gentes hacen lo mismo cuando visitan un monumento o un lugar pintoresco. Los huecos de todas las ventanas estaban constelados de nombres, de fechas y de direcciones. La mujer se servía de su lápiz de cejas: veía brillar entre sus dedos el pequeño cilindro dorado.

"La falsa Lollobrigida" - lo sabremos después- daba cita al asesino de su marido . Y, dentro del mismo ámbito policial, el acto puede ser harto más provocativo: una de las complejas muchachitas de Agatha Christie bosqueja un árbol — "el árbol Ygdrasil" lo llamará Poirot - sobre la pintura verde de una mesa de 
hierro para ingresar en el número de los sospechosos y despistar - sin conseguirlo- al sagaz y también complejo detective ${ }^{6}$.

Ignacio G. Anzoátegui (practicábamos entonces, aprendices malos de griego, la crasis) ha tratado, en sus Vidas de muertos - con discutible ingenio, con indiscutible mal éxito-, de reunir las dos jurisdicciones extremas (la temporal reclusión voluntaria, y la impuesta y prolongada que han ilustrado Erik Satie y los Canti di prigionia) a propósito de unos versos de José Mármol trazados in carcere et vinculis rosistas (" $\mathrm{mi}$ cárcel y cadenas", sostiene en ellos, apostólicamente, el poeta $)^{7}$. No pueden echarse a burla estas inscripciones carcelarias, ya sean emotivas o didácticas como las que Alejandro Dumas contrapone, en la celda del futuro Conde de Montecristo y en el meridiano diseñado en la del abate Faría ${ }^{8}$, como no las echó a burla la escuela lombrosiana que floreció en Italia a fines del siglo pasado; lo recuerda Francisco Ayala en sus propios Recuerdos y olvidos. Michel Bongrand, aprisionado como miembro de la Resistencia francesa, puede hoy cantarnos, felizmente, lo que vio en los muros de su cárcel y lo que agregó en ellos:

Il y avait des noms sur les murs de ma cellule.

Tant et tant de noms d'hommes passés en prison.

Il y avait aussi des bateaux dessinés,

Des petits et des grands, et des bateaux à voiles

Qui semblaient mordre l'horizon.

J'aurais voulu remplir les bateaux de ces noms,

Les bateaux en crayon de ces noms en crayon.

C'est alors que j'ai vu - j'avais tellement froid-

Que j'étais en prison, prison sans horizon,

Et moi, j'ai dessiné, simplement, ma maison ${ }^{9}$.

La misma poesía popular se ha apoderado de la acción y su cuadro, con su oposición de encierro y libertad:

Cuando yo estaba en prisiones

en lo que me entretenía

era en escribir tu nombre

en los ladrillos que había ${ }^{10}$.

Deplorante, jubilosa, o sencillamente desmedrada, la inscripción responde, siempre, a un imperativo más o menos categórico de comunicación, a un puente tendido entre el yo que borrajea y sus presuntos, presumibles o aleatorios leedores, incluso cuando la reclusión forzada convierte al inscriptor en lector señero y en testigo casi integral de su existencia: un buen novelista uru- 
guayo enhebra, en la conducta de un preso político encapuchado, estos dos imprescindibles polos de la transmisión:

Con las puntas de los dedos, leía los mensajes que otros habían dejado, con uñas o botones rotos, en las paredes. Todos sentimos, andá a saber por qué, esa necesidad de escribir: estuve aquíi ${ }^{11}$.

Andá a saber por qué. . . La expresión es ajustada. Jean Giono precisa, precisamente, su doble ingrediente de necesidad e imprecisión al precisar el hueco de una determinada ventana en el segundo piso de un cuartel, en el castillo de Briançon:

Je me souviens que j'ai marqué quelque chose dans la pierre à cet endroit-là; je ne sais plus exactement quoi; mais je me vois encore en train de gratter avec la pointe de mon couteau et somme toute assez content de m'occuper à ça ${ }^{12}$.

Necesidad quizás indefinida de afirmar su pasaje y sus paisajes interiores: en verdad, necesidad de afirmarse. Así lo confiesa una ilustre poeta, ferviente sacerdotisa del "culte du moi":

. . . j'écrivis de petits morceaux de musique que ma mère fit relier dans un album de l'aspect le plus sérieux. Je demandai et j'obtins facilemente qu'on inscrivît sur le cuir, couleur de noisette, en lettres d'or, le nom d'Anna. Sur quoi n'ai-je pas, de ma main d'enfant, écrit ce nom? Le besoin où se trouve un petit être de se constituer le porte à reproduire le plus qu'il peut le signe qui le représente. Écrire sur des cahiers, sur des livres, sur du papier buvard, sur des cartons à chapeaux, sur le sable des allées, le nom d'Anna, équivalait certainement à ces médications fortifiantes qu'on donne aux enfants pour assurer le bon état et la croissance des ${ }^{13}{ }^{13}$.

Necesidad de afirmarse: y más aún, voluntaria fatalidad de nuestro "estuve aquî", formulada de varias maneras y formatos:

Por doquiera que pasa el hombre va dejando rastros de su tránsito. Un nombre grabado en el tronco de un árbol, una lápida, una estatua, un monumento cualquiera, una pirámide, son indicios seguros de que desciende satisfecho al sepulcro si logra que su recuerdo quede entre los que le sobreviven ${ }^{14}$.

Especie muy dilatada de la "idea de la fama" es hacer vivir la memoria del nombre ("Murió el homme mas non murió el nom- 
bre", la formulaba Don Juan Manuel). Dejar ese nombre escrito es una manera de integrarse en la realidad casi —en más modesto- $\tan$ inamovible como la perduración de los nombres geográficos que sobreviven a veces a migraciones y culturas:

\author{
Marquises, Carolines, \\ Votre nom sur la carte. \\ Grave le mien dans l'arbre \\ Près de la balançoire ${ }^{15}$.
}

El albergue del hombre, voluntario o forzado, suele irse cubriendo con todo género de inscripciones: en primer término, naturalmente, sus paredes, pero también las puertas y celosías, las columnas, y hasta las vigas del techo y los vidrios de las ventanas: los muebles no salen mejor parados, sean camas, biombos o mesas de café. Ni las tumbas se salvan, y ni siquiera el ápice de la cúpula de San Pedro de Roma está asegurado de grafios y de gráficos ${ }^{16}$.

$\mathrm{Al}$ igual de todos los lugares, todos los materiales pueden prestarse a este fin:

La mayoría tenía nombres de flores [ ...]. Los grababan en los troncos de los árboles, con uñas duras como de tigre; los escribían en las paredes, con lápices carcomidos; en la arena húmeda, con un dedo ${ }^{17}$.

¿Excluiríamos razonablemente la propia piel de la persona?

N'avez-vous pas chacune de vous votre nom écrit sur une jambe au moyen d'un tatouage? ${ }^{18}$.

Pero entre todos los soportes de la escritura hay, como en todo, diferencias. El agua que huye o cede ha sido siempre símbolo de irrestañable inconstancia: tanto, que la manejada imagen del río que no vuelve atrás atraviesa la poesía amorosa, los cuentos infantiles y el habla cotidiana. Pretender escribir en tan fugitiva materia es emblema de falsedad, en hombre como en mujeres:

... que traydores son los hombres, como sus promesas falsas muerto el fuego desparecen como escriptas en el agua ... ${ }^{19}$ 
...y promete que jamas

creera de mujer palabra,

porque son plumas en viēto

o escrituras en el agua ${ }^{20}$.

Cuando escribirme pretendas

de papel sírvate el agua,

y así durará más tiempo

lo que escribes en tus cartas ${ }^{21}$.

... No tengo nada aquí, quien por mí siente

viene a escribir su nombre sobre el agua ${ }^{22}$.

Deseo de olvido, denegación de lo perdurable, el felizmente falaz epitafio de Keats reaparece en boca de un personaje de Galdós:

... quiero que mi nombre no exista más en la memoria de nadie, a no ser en la de aquéllos que lo pronuncien para ultrajarme, y que mi persona en el mundo sea como una figura trazada en el agua $^{23}$.

Escribir en el agua es, en fin, parangón de lo imposible, de lo inusitado, de lo inútil:

Tan imposible parece

que tú puedas olvidarme,

como escribir en el agua

y echar una piedra sangre ${ }^{24}$.

El quererme a mí quitar

tu querer del pensamiento,

es escribir en el agua

y predicar en desierto ${ }^{25}$.

Incluso la efímera solidez del agua endurecida por el frío participa del mismo descrédito por lo que toca a su validez: ya en Berceo la Virgen apostrofa a Teófilo diciéndole: "Sobre yelo escribes"' (Milagros, 778 b), y la expresión corre hasta Darío - “Hace una hora que un nombre grabé sobre la nieve"', Versos de otoñoy llega a la correspondencia de Gide: “ . . . et je fais des écriture sur la glace" (a Paul Valéry). Bernard Clavel denomina igualmente sus reflexiones Écrit sur la neige, y epiloga: “ . . nous écrivons toujours sur la neige. Le tout est de savoir à quelle heure se lèvera la tempête"'26. 
Idéntica inconsistencia e idéntica inconstancia son las del polvo ${ }^{27}$, y por ello López de Zárate aconseja confiarle tanto la conciencia de la dádiva como la de la ofensa recibida:

Da con verguença, como quien recibe, esto y ofensas en el polvo escribe... ${ }^{28}$

La arena es en todo similar al polvo: "O palabras escriptas en la arena", suspiran en la Comedia del perseguido ${ }^{29}$ y el romancero nuevo lo repite:

... que aficiones de muger

son letras en el arena, que o las pisan pies agenos

o las cubre nueva tierra ${ }^{30}$.

Con todo quiero adorar

lo que en tu papel vi escrito:

pues, por letras en la arena

mas de vno perdio el sentido ${ }^{31}$.

La copla popular recoge la imagen:

El juramento mi niña

lo escribió sobre la arena;

lo que en la arena se escribe

viene el viento y se lo lleva ${ }^{32}$.

Más efímera que lo que la etimología significa es la inscripción de Bilitis: "Et moi, dans la pluie du matin, j'écris ees vers sur le sable. ... La pluie, goutte á goutte, fait des trous dans ma chanson" 33 . Trazar letras y figuras en la arena es ocupación no desusada en la poesía cantable española del período clásico:

Halléos ayer con pena, el semblante triste y ledo, escribiendo con el dedo cierto nombre en el arena... ${ }^{34}$

... porque la mano alargo

a la arena que mirava

do con el dedo escrivió.... ${ }^{35}$

$\mathrm{Y}$ un soneto de los Tonos antiguos ${ }^{36}$ muestra un retrato de Alfeo trazado en la arena. 
En su infidelidad, agua o arena dan lo mismo:

\author{
¿Quién dudara de promesas \\ con lágrimas rubricadas, \\ de palabras no guardadas \\ en agua, en arena impresas. . . ?37
}

Ambas se oponen al deseo de perdurar propio de quien escribe:

El oficio de poeta no puede ser más sencillo, es lo mismo que escribir en la arena o en las aguas, es confiar las palabras a un animal que no comprende y mira con tranquilidad ${ }^{38}$.

Idéntica tarea sería la de escribir en el viento, imagen que figura entre los tópicos de infidelidad femenina estudiados por Fucilla; "in vento et aqua scribere" se leía ya en Catulo ${ }^{39}$. Por ello Lope (o López de Zárate) opone, en materia de amores, soportes más duraderos a estos efímeros:

...pues tú, Filis, en ondas y en arenas, yo en árboles y riscos escribía...

reiterando la adjunción al reino mineral del de los vegetales:

Quede por las cortezas

de aquestos verdes árboles, ingrata fiera, con mi fe tu nombre;

imprima en las durezas

de aquestos blancos mármoles

mi ejemplo amor, que a todo el mundo asombre. . ${ }^{40}$

No falta, sin embargo, quien desdeñe el árbol y le prefiera piedras y metales como más permanentes: Góngora - usando también el clásico ejemplo de equivalencia acústica- coloca la prosapia del traductor de Las Lusíadas, Luis de Tapia, “más que en árboles, / en bronces, piedras, mármoles", en sus propios versos; y si bien sostiene que a los amantes refugiados "En un pastoral albergue", "los troncos les dan cortezas / en que se guarden sus nombres / mejor que en tablas de mármol / o que en láminas de bronce", confía más en las piedras que en las plantas, en el canto nupcial de sus Soledades ${ }^{41}$. Escribir en el árbol, sin embargo, que está más a la mano, más a la altura de la mano, y es más compadeciente con el esfuerzo de la mano, es "costumbre de enamorados", en esta tierra y en su esperanza: 
Grababa mi nombre en los troncos de los árboles, con su cortaplumas, y durante las penitencias lo escribía con tiza, en la pared.

- Cuando me muera le regalaré todos los días bombones y escribiré su nombre en todos los troncos de los árboles del cielo- me dijo un día ${ }^{42}$.

De enamorados, y, con ellos, de todos los que pretenden perpetuar sus conquistas ("Ces nymphes... " y demás): un artículo que conmemora el centenario de Pierre Savorgnan de Brazza (la ciudad congolesa de Brazzaville ilustra su nombre) reproduce la imagen de "Un baobab au bord de la route, où restent gravés son nom, celui de ses compagnons, et une date: 1887'"43. Más cerca, en tiempo y en espacio, Émile Henriot describe cómo

partout dans le village [Nesles], la canaille a complété l'ouvrage du vainqueur, l'ignoble dégât des soldats ivres. Le saccage d'ailleurs est signé. On m'a signalé, dans le jardin, le long de la haie, ce bel arbre où les occupants ont gravé leur marque, très artistement: un aigle éployé, accompagné d'un Heil Hitler! avec la date, 13 juin $1940^{44}$

Hasta yo mismo puedo acusarme de haber incurrido en esas (en mi caso) no del todo conscientes jactancias: en uno de mis primeros viajes recordados al campo nuestro de San Vicente - "campo nuestro" tiene aquí el mismo valor afectivo que en el libro homónimo de Oliverio Girondo-, Sarita Fariña, la hija menor del casero, me inició en el delicado arte de inscribirse, con un alfiler y sin espinarse demasiado, en las robustas palas de la higuera de tuna, donde la agresión cicatriza pronto y reemplaza la herida por una línea blanquecina. ¿Qué lejos estaba, con mi incierta orto-caligrafia de entonces, de sospechar que, sobre imitar a las sibilas ${ }^{45}$, procedía casi como los pastores de Virgilio! Eso sólo lo supe muchos lustros después, en el tiempo en que María Rosa Lida, generosa de sus muchos saberes, alentó y alimentó mi interés por el tema, enseñándome que el saber no comunicado - al igual (según William Blake) que el deseo reprimido- engendra la putrefacción, y que hay que aprender a saber recibirlo y a saber agradecerlo, sabidurías que no siempre van de la mano. Era por el tiempo en que Alberto Salas, ya empapado en cronistas, nos transmitía la fórmula (tan viva hoy): "Pared blanca, papel de necios". Papel de enamorados fueron los troncos en la literatura pastoril: "papel"' los dijeron, y repetidamente, Góngora, Lope, Tirso, Esquilache. . ${ }^{46}$; y en la novela, como en la poesía, las repetidas, 
apasionadas escrituras cubren indiferentemente árbol o planta, en tronco, corteza, ramos o cogollo ${ }^{47}$. No hay especie vegetal que escape a su hazaña (casi se diría "su saña"'): olivos, fresnos, alisos, morales, laureles, robles, olmos, álamos, encinas, pinos, sauces, hayas, palmas, cipreses, abetos y manzanos, y mezcla de estas diversas especies, todos son pasados a cuchillo ${ }^{48}$. Como en otros ilustres soportes de lo escrito, también en el árbol anida el palimpsesto, como corolario de inconstancias:

Dardanio, con el cuento del cayado

el nombre y la figura deshazía

de aquella ninpha, que él antes avía

en mil cortezas de árboles pintado ${ }^{49}$.

Verdes álamos del Tajo,

si en vuestras blancas cortezas

escribí celoso y triste

mucho amor y muchas quejas:

enamorado y quejoso

a borrar vengo las letras,

que ya mi engaño las forma

en un corazón de piedra ${ }^{50}$.

Andando a solas un poco

ayer, sin vos y sin mí, en un álamo leí:

nunca mucho costó poco;

mas yo, que sé cómo lucho

con deseo y con trabajo

borrélo y puse debajo:

nunca mucho costó mucho ${ }^{51}$.

Ninguna queja más tierna que la del Romancero General de 1600:

De la arrugada corteza

de vna aya borra Filis

su propio nombre, y abaxo

oluido pone y escriue ${ }^{52}$.

Abolir la escritura que se deseó duradera, borrar como castigo el nombre que alguien quiso perpetuar ${ }^{53}$, equivale a librarlos a los vientos que son inestables y a esparcirlos por las tierras que no saben oír: así lo siente y canta la Diana de Gaspar Gil Polo, ejemplo solitario de renuncia a la fijeza del lamentar pastoril: 
Canción, si en algún pino ó dura encina no quise señalarte, mas antes entregarte al sordo campo y al mudable viento: porque de mi tormento se pierda la noticia y la memoria, pues ya perdida está mi vida y gloria... ${ }^{54}$

Repetidamente escrito, borrado un poco menos repetidamente, correspondido o no, el testimonio del amor pastoril confiado al árbol refleja un uso general pero exasperándolo hasta lo no creíble: un editor de las bucólicas virgilianas apunta, con cuerda sensatez, que sin duda no se escribirían de este modo más que algunos versos, y no poemas enteros ${ }^{55}$; pero los imitadores del mantuano no lo entendían tan corto: ya el "epitafio de la ninfa bella" ocupa, en la Égloga III de Garcilaso y en la corteza de un álamo, una octava (p. 134 de la edición de Navarro Tomás); sobre las octavas funerarias, no falta el reincidir un soneto, ni quien imprime —el Tirsi de Gálvez de Montalvo- tres octavas reales. El Lucinio que se ha visto llorar ante un verde tronco, escribe en él más de dos páginas del tomo III de las Fuentes (f. 59-60); lo que " Zelindo escriuio / en el tronco de vna haya" 56 cubre los treinta y dos octosílabos precedentes (¿haya, o columna de Trajano?); los solos versos rescatados, entre los que Don Quijote grabó en cortezas y menudas arenas, no son menos de tres coplas de once versos cada una (I, XXVI), y en la Égloga $I I I$ de Hurtado de Mendoza un interlocutor que parecería conocer el valor del momento ('Si tuviéramos tiempo te contara / lo que está escrito en un ramo verde", dice en comenzando), empieza por el poco inesperado topos del río retrógrado ${ }^{57}$, para seguir leyendo su escritura durante treinta y ocho endecasílabos en terza rima. Más abundoso y pre avido aparecería el Artidoro de La Galatea cervantina al repartir por muchos álamos las veinte cuartetas octosílabas que estampa:

... se me ofreció a los ojos un cortecido álamo blanco, que delante de mí estaba, en el cual y en otros muchos vi escritas unas letras, que luego conocí ser de la mano de Artidoro, y levantándome con priesa a ver lo que decían, vi, hermosas pastoras, que era esto: $[\ldots]$

Por más versos agudos que haya, las veinte coplas constan de muchas sílabas y de muchísimas más letras, y todas ellas parecen lo- 
calizadas en un solo tronco, si dice verdad la apasionada reacción de su pastora, que vemos " abrazando mil veces la corteza [y no "las cortezas"] donde las manos de mi Artidoro habían llegado" 58 .

Pero es Pradelio el que saca (o seca) la palma al dejar en las proximidades de la cabaña de Filena, en la corteza de un solo álamo y en casi dos columnas de $E l$ pastor de Fílida ${ }^{59}$ una "piadosa despedida" (que no lo es para él ni para el álamo) en diez y seis liras: apenas ochenta versos de siete y once sílabas; y no es simplemente furia hispánica: en una égloga de Bernardino Baldi un aliso, escrito "dal sommo a l'imo" — "desde la planta al penacho", dice un español-, lleva setenta y un versos de las mismas medidas, entre los que sólo diez de ellos son quebrados ${ }^{60}$. El tiempo de inscribirlos debería haber contado también con el cansancio de hacerlo: los árboles y su corteza son a veces verdes, lo que no califica su resistencia al cuchillo (y lo mismo puede pensarse de las "tiernas hayas, pinos y sauces" de Lope de Rueda; más precisas serían las tiernas cortezas de Trillo y Figueroa), pero en general -aparte tres menciones que conozco de su lisura: Góngora, Lope y un anónimo- se insiste en la dificultad incisoria (troncos rudos, en Vélez de Guevara; duro y pardo, para Medina Medinilla; frente a unas cortezas delgadas de un anónimo, otro anónimo las dice toscas, y Góngora, Figueroa y Sanz del Castillo las califican de duras; "dura encina" es la de'Juan de la Cueva; Góngora reconoce la dureza del laurel y del roble). "Hondo supe escribillo", se jacta Soto de Rojas, y el viejo Sileno, en El pastor de Fílida, traza una imprenta rusticana "como vido el trabajo con que se escribía en las cortezas"' (p. 464). A la longuería de lo escrito añádase la pertinacia de los escritores, que no dejan vegetal tranquilo: "No hay planta en todo aquesto. ..." (Juan de la Cueva), "Ni pienso que algún olmo o salce hubiese..." (Hernando de Acuña), "No hay en todo el valle / álamo acopado..." (Arbolanche), "Que no hay álamo blanco en nuestro río. . " (Lope de Vega); el poeta y su personaje se confiesan "importuno", garabateando todos los árboles que encuentran, "sin perdonar de aquestos campos uno" (Pedro Soto de Rojas): y estos todos, "en tanta parte heridos"'.

Más todavía: olvidados de la superstición condenada por San Agustín y ajenos todavía de las experiencias actuales sobre la sensibilidad vegetal ${ }^{61}$, estos poetas incisivos creen galardonar el árbol a pura cuchillada, y lo aseguran: 
... árboles doléos de mí, ramas encubridme agora que os prometo de escriuir mi amor en vuestras cortezas, porque os hagan mis firmezas eternamente vivir ${ }^{62}$.

...Aquella, por quien todo tronco altiuo (si lo toca su nombre) reuerdece, como lo has visto en muchos que lo escriuo ${ }^{63}$.

A este alegre exceso se contrapone la alegre burla de Sansón Carrasco: para ser dignamente pastor, dice,

. . lo que es más menester, señores míos, es que cada uno escoja el nombre de la pastora que piensa celebrar en sus versos, y que no dejemos árbol, por duro que sea, donde no la retule y grabe su nombre, como es uso y costumbre de los enamorados pastores ${ }^{64}$.

Donosa burla del Cervantes de la Segunda parte al Cervantes de la Primera, que en su capítulo XII hace decir al cabrero:

No está muy lejos de aquí un sitio donde hay casi dos docenas de altas hayas, y no hay ninguna que en su lisa corteza no tenga grabado y escrito el nombre de Marcela, y encima de alguno, una corona grabada en el mesmo árbol, como si más claramente dijera su amante que Marcela la lleva y la merece de toda la hermosura humana ${ }^{65}$.

La burla de "los libros de los pastores" (La Dorotea, p. 296 de la edición de Américo Castro) llega casi a tornarse tópica, y Quevedo la suma a la del romancero morisco:

... después que dejaron de ser moros - aunque todavía conservan reliquias de ello- [los poetas] se han metido a pastores, por lo cual andan los ganados flacos, de beber sús lágrimas [etc. $]^{66}$.

Pero los moros también - con Medoro a la cabeza- fueron igual de secantes, como el romance lo prueba:

Al pie de vn alamo blanco, en cuya tierna corteza escriuieron otros moros mil enamoradas letras. 
El desesperado Zayde, los ojos puestos en ellas, mira las cifras y lazos, los corazones y letras ${ }^{69}$.

El fastidio de cantar y de oír cantar la operación se manifiesta en una pieza satírica de Trillo y Figueroa, en la que manda al Amor

$$
\begin{aligned}
& \text {...que a los bobos vaya } \\
& \text { para que dibujen } \\
& \text { cifras por los troncos } \\
& \text { de los acebuches }{ }^{68} \text {. }
\end{aligned}
$$

Dos corrientes alimentan estas paludes, donde tanto el común y cotidiano deseo de dejar nuestra huella como su más fácil realización descienden a tópico: una es la imitación directa de la bucólica antigua, y la otra su afluente, la imitación de la poesía pastoril italiana, voluntariamente grecolatina desde su fundador Boccaccio ${ }^{69}$. Beber en esas aguas es no sólo recomendable, sino obligatorio. Siempre que lo pillado provenga de esas fuentes, su trasvase cobra, sobre licitud, elegancia: lo censurable es saquear a sus vecinos de lengua (salvo cuando la cita sea declarado homenaje), y así lo entiende, en El pastor de Fílida, el censurador de Silvano:

Y no hurtáis, Silvano, del latino, del griego, del francés o del romano, si no de mí y del otro su vecino ${ }^{70}$.

Del latino primeramente debe hurtarse, y un poco más allá, y otro poco indirectamente, del griego; y directa e indirectamente, de los italianos, que hacen lo mismo. El patrón - para hurtar el inequívoco equívoco con el que Valery Larbaud caracteriza a San Jerónimo- el indiscutido padre y padrón de la poesía pastoril renaciente es Virgilio ${ }^{71}$, y notoriamente en esto de escorchar cortezas:

Immo haec in uiridi nuper quae cortice fagi carmina descripsi et modulans alterna notaui, experiar. . . 72

Fray Luis ${ }^{73}$ escatima al traducirla el nombre del árbol: 
Mopso: Antes aquestos versos que he compuesto Quiero probar agora los primeros. En la corteza escritos los he puesto De un árbol, y su tono les he dado...

(cuando "de un árbol" mide tanto como "de un haya" o incluso "de una haya") $)^{74}$; más semejante es la versión de Cristóbal de Mesa:

Mas los versos dirè, que dexê escritos en la verde corteza de vna haya, y los cantè, y tañi vezes distintas...

Juan del Encina, en su libre versión, lo escatima todo:

Mosso: Antes otras cantilenas te quiero agora cantar que cuydo $\bar{q}$ son muy buenas q aun agora agora a penas acabo de pernotar... ${ }^{75}$

Y Diego López lo aumenta y lo comenta:

Mopso: Antes experimentaré estos versos, los cuales poco ha escribí en la verde corteza de la haya, y notélos cantando unas veces con guitarra, otras con la boca... ${ }^{76}$

La preeminencia de Virgilio se manifiesta por doquier: el Silvano de Hernando de Acuña, que grabó -o gravó- olmos y sauces en honor de su Silvia77 la enaltece sobre "la Musa de Damón y Alfesibeo"'78. Claro está que el "Pastor de Mantua"79 no está solo: Propercio reparte por las selvas escritura y querellas:

... quoties teneras resonant mea verba sub umbras,

Scribitur et vestris Cynthia cortibus. . . ${ }^{80}$

María Rosa Lida me apuntó, años ha, los textos similares de sus sucesores Calpurnio y Nemesiano, elogiadores del hospitalario cerezo $^{81}$, y más tarde, en su espléndida reseña de Curtius, puso junto a la égloga décima de Virgilio la heroida quinta de Ovidio que también destiñó en la poesía de lengua española ${ }^{82}$. Pero si los poetas "romanos" fueron razón de imitaciones numerosas, fueron también ellos imitadores del "Primus graius homo". Teó- 
crito da un ejemplo - uno, sólo- de la costumbre de escribir en las cortezas de los árboles:

Ante todo, te entretejeremos una corona de loto, que crece en el suelo, y la colocaremos en el sombroso plátano; ante todo, tomaremos de un pomo de plata líquido ungüento y lo destilaremos bajo el sombroso plátano, y en la corteza quedarán escritas letras para que algún pasajero las recaja: "Venérame con dones, soy el árbol de Helena" ${ }^{83}$.

Y Trillo y Figueroa, en su imitación de una oda anacreóntica, avina el topo ${ }^{84}$. Pero, como lo afirma la enmienda a la nota pertinente - ¿o no pertinente? - de Curtius, es el hallazgo de Virgilio y de Ovidio, continuando las tradiciones estudiadas por Comparetti y por Faral, el que graba más profunda estela en la poesía de los siglos áureos. La égloga quinta del pastor de Mantua proyecta un reflejo, si no contradictorio, irisado en quienes la vierten; la décima y final, en cambio, mantiene un invariado impacto:

...malle pati tenerisque meos incidere amores arboribus: crescent illae, crescetis, amores,

da, sin posibilidad de discutirlo, "prefiero sufrir y grabar mis amores en los árboles tiernos: éstos crecerán y creceréis, amores". Si cabe algún embellecimiento - que siempre cabe- la paridad de uno y otro crecer seguirá en pie ${ }^{85}$, y rebrotará (o rebotará), copiosamente copiado, en Montemayor, Francisco de la Torre, Juan Rufo, Pedro de Padilla, Lomas Cantoral, Cetina, Pedro de Salas, Trillo y Figueroa, Esquilache, Francisco de Figueroa, Cervantes, Lope, Quevedo, y Dios sabe cuántos más ${ }^{86}$. Pero tanto como la imitación directa de Virgilio pesa sobre los poetas españoles del Siglo de Oro la imitación de los bucoliastas italianos que imitaron a los antiguos. El primero, y el más virgiliano, es, naturalmente, Jacopo Sannazaro: su más notante editor, Scherillo, que apunta repetidamente sus deudas para con Ovidio y Propercio, reconoce que "il vero maestro ed autore del Sannazaro, colui al quale si diede per sua salute, il suo dolcissimo padre, è Virgilio..." "87. Si la influencia de Sannazaro se ejerce razonablemente sobre sus conterráneos ${ }^{88}$, basta recorrer el índice de las Relaciones hispanoitalianas de Fucilla para aquilatar su impacto en Cervantes, Gil Polo, González de Montalvo, Balbuena y otros más ${ }^{89}$; y Tirso de Molina lo hace proclamar abiertamente por uno de sus fingidos pastores, que dice de otro que 
escribe en troncos diversos

por las márgenes del Po

lo que en la Arcadia leyó. . . ${ }^{90}$

En el proemio de su libro, Sannazaro equipara las silvestres canciones arbóreas, que siembra a manos llenas en él, con los cultos frutos de la poesía libresca (guardándose de susurrarnos que todos son unos): "addiviene che le silvestre canzoni vergate nelle ruvide cortecele de' faggi dilettino non meno a chi legge, che li colti versi scritti nelle rase carte degl'indorati libri..." (citado por Fucilla, p. 65). No carece sin embargo de razón un moderno estudioso del género pastoril al opinar que

Sannazaro abuse des cigales, des grillons et des oiseaux pour peindre un coucher de soleil; ses bergers ne se lassent pas de graver le nom de leurs belles sur l'écorce des hêtres ou des ormes: de telles redites sont fastidieuses ${ }^{91}$.

Otros poetas italianos dejan en España su huella xilográfrca: así los tres pasajes del Aminta de Tasso vertidos por don Juan de Jáuregui ${ }^{92}$ : se dan como salidos de su Gerusalemme los versos semejantes de $E l$ Vasauro de Pedro de Oña, y un buen retórico dieciochesco no encuentra mejor ejemplo de "patético" que la ocupación de Herminia, abandonada de Tancredo y viviendo como pastora: "Una tarde de julio, mientras las ovejas descansaban à la sombra, se entretiene grabando unos caractères amorosos en la corteza de los cypreses:... Árboles ... conservad la historia de mis penas..." (etc. ${ }^{93}$; así el par de imitaciones de Varchi que señala Zamora Vicente en su edición de Francisco de la Torre; y así Tansillo con tantos otros más ${ }^{94}$. Pero es seguramente el idilio pastoril del Orlando Furioso el que despierta mayor número de resonancias en la poesía castellana: Ariosto narra en el canto XIX de su poema los amores de Angélica y Medoro con su consecuente poligrafía y, cuatro cantos más adelante, el efecto que esas inscripciones producen en el desamado paladín:

Fra piacer tanti, ovunque un arbor dritto

Vedesse ombrare o fonte o rivo puro,

V'avea spillo o coltel subito fitto;

Così, se v'era alcun sasso men duro.

Et era fuori in mille luoghi scritto,

$\mathrm{E}$ così in casa in altri tanti il muro,

Angelica e Medoro, in vari modi 
Legati insieme di diversi nodi.

(Canto XIX, 36)

Volgendosi ivi intorno, vide scritti

Molti arbuscelli in su l'ombrosa riva.

(Canto XXIII, 102, 1-2) ${ }^{95}$.

Sobre la traducción integral de Jerónimo de Urrea, el relato mismo tentó a los autores de romances noticiosos (Pedro de Padilla, Lucas Rodríguez) y a los poetas del romancero nuevo; sus consecuencias dejaron huella en el Quijote y tal cual alusión en las comedias, motivando uno de los más frecuentados romances de Góngora ("En un pastoral albergue" suscitó incluso otro de López de Zárate); Góngora mismo alude, en otro de sus celebrados romances, a la celosa furia del desdeñado, para salvaguardia del lujurioso abrazo del tronco y la vid. Y Lope de Vega, cantor de la hermosura de Angélica y escenificador de sus amores con $\mathrm{Me}$ doro -introduce en la pieza la demanda de la bella y el "crescete" virgiliano-, combina el ser provocado de Ariosto con su afición por los libros de pastores ${ }^{96}$.

Casi todo lo consignado hasta aquí procede de la poesía pastoril tomada en su más contrálgido fervor (o, si se quiere, hervor), si bien -como se lo repite desde el incipio- el deseo de perpetuar un mensaje viene de más lejos y nos llega más de cerca. En la poesía española ulterior se sigue perpetuando esta maniobra, ya por un íntimo movimiento del ánima, o el ánimo, ya por el rebote, más o menos disimulado, de un procedimiento literario que ha probado ampliamente su valía: en la vida de un pastor rebajado - no se llama Anfriso, ni Daliso ni Merotiso, sino Perico del Campo- el desesperanzado requiere muchas encinas para un solo soneto, grabado a cuchillo antes de despedazar su flautilla. Meléndez Valdés cultiva una sola "corteza entallada" (ricamente ilustrada, eso sí, "de mil símbolos sencillos"); Iriarte se propone fijar en arenas y cortezas un nombre que desearía olvidar; el del Elmira lo repite Quintana tantas veces como lo grabó en la corteza del duro roble; Arolas emplea el buril para afrontar la corteza del sauce; Espronceda cifra su gloria en la cifra que grabarán oficiosas ninfas; Gavarni, románticamente, "graba un nombre del sauce en la corteza", según Manuel Machado; y según su hermano Antonio, "esos chopos del río" - hermanos en discreción de los cantados por Juan de Jáuregui- "tienen en sus cortezas/grabadas iniciales que son nombres/ de enamorados, ci- 
fras que son fechas"; y Pérez de Ayala recurre, como antes Trillo y Figueroa, a árboles de resonancià nada poética para emplazar una saeta que traspasa un corazón, "según se ve en los emblemas de fidelidad perdurable con que los enamorados suelen entallar la corteza, suberosa e insensible, de los alcornoques", escrituras más fácilmente descifrables que las de otros grimorios ${ }^{97}$. También la poesía popular (y la que la imita) recogen la operación incisiva, ya en su clima más tierno, ya en diversas maneras de ponerla en solfa ${ }^{98}$. La universalidad del gesto es tal que puede pasearse del lejano Oriente a Escandinavia ${ }^{99}$; el azar de lecturas algo más dispersadas lo topa, Pirineo por medio, de la Pléiade a L'Express, pasando por Parny, Víctor Hugo, George Sand (o Jules Renard), Gide, Valery Larbaud, Miomandre, Arland y otros más ${ }^{100}$ : inclusive el "crescete" virgiliano repercute en Edmond de Goncourt, Gabriel de Lautrec, Giraudoux, el cuidadoso novador que es Cocteau, en Dürrenmatt y hasta en el peregrino cubano José Luis Alfonso ${ }^{101}$. Y la pintura -real o literaria- nos pone la acción ante los ojos, en la "Lettre d'amour" rococó como en el retrato de Mrs. Lloyd por Reynolds conservado en el Musée Cognac-Jay de París, y en un relato terrífico de Ewers como en Le fanal bleu de Colette en cooperación con Jean Marais ${ }^{102}$.

La poesía americana de lengua española no podía faltar a la cita. Sobre labrar en árboles indeterminados o ya conocidos (cedro, ciprés, roble, eucalipto) ${ }^{103}$ su mejor novedad consiste en el aporte de maderas del país: "Lo grabaría yo sobre la seca / madera de mis árboles nativos", proclama el maestro Alfonso Reyes ${ }^{104}$. De sur a norte (aunque con la obligada preponderancia de las del mío), vamos del ombú:

$$
\begin{aligned}
& \text { En su tronco se ven cifras } \\
& \text { grabadas con el cuchillo, } \\
& \text { quizá por algún caudillo } \\
& \text { que a los indios venció allí; } \\
& \text { por uno de esos valientes } \\
& \text { dignos de fama y de gloria, } \\
& \text { y que no dejan memoria } \\
& \text { porque nacieron aquí!... }
\end{aligned}
$$

... Se acuerda el ombú viejo en que me enseñastes a conocer las letras, haciéndome escribir con mi puñal tu nombre ${ }^{106}$.

Gien años! Cada arruga es como un tajo que lo hizo cicatriz algún ricuerdo. 
Ya no queda cuchillo en todo el pago que no haiga puesto el nombre de su dueño.

Letras que son promesas de los novios y grabaron allí pensando en ella. Es un tatuaje gaucho, claro y hondo, que el ombú va a guardar hasta que muera ${ }^{107}$

al pacará:

Abuelo. Mira, Azucena, mira el viejo pacará, a cuya sombra crecieron tres generaciones. Todavía se ven en su tronco carcomido las iniciales entrelazadas de los novios que, como un juramento de amor, grabaron en su corteza, confiando en la buena sombra que les darían sus ramas...

Centeno. No, Azucena, no la engaño. Este buen árbol, será también depositario de nuestro amor. ¡Por él se lo juro! Desde hoy su tronco ostentará dos nuevas iniciales: la de usted y la mía. Las voy a grabar tan estrechamente enlazadas, tan estrechamente unidas, que las dos no van a parecer más que una sola. ¡Mire usted!. . . Empiezo por la A, su nombre, Azucena. (Graba con un cortaplumas en la corteza del árbol) ${ }^{108}$.

al molle:

Ese molle que inclina su ramaje á la corriente tardía conserva en el tronco carcomido como la estrofa trunca de un idilio, cifras enlazadas que grabó un amante venturoso ${ }^{109}$

al huil, grabado por precaución:

... la leyenda dice que [el huil, la Eugenia cisllatensis] es albergue de almas en pena y es la causa por que los lugareños casi lo han extinguido, pues árbol que había cerca de las casas lo talaban, y a los que estaban retirados les hacían una cruz, calándole[s] la corteza $^{110}$

al mango:

"En el tronco de un mango miró hecho a puntilla en la corteza hecho un corazón"'111

y así subimos de la cursilonería de la magnolia a la franca picardía de los melones, émula de Quevedo: 
Y Juancho contaba una larga historia con entierros y aparecidos que databa de los tiempos del patrón don Felipe y agregaba que fue con ese facón que su señor y cierta dama grabaron sus iniciales en la magnolia un 29 de febrero. No había restos en el viejo tronco, pero desde entonces cada año bisiesto florecía una magnolia ensangrentada $^{112}$.

. . el mozo que "huele a corral" [personaje de Los mirasoles de Julio Sánchez Gardel] y declara su amor sin éxito al esculpir sus frases en la corteza de los melones... ${ }^{113}$.

No todo lo grabado en el árbol es testimonio amoroso (o erótico, que es lo mismo sin serlo: testigo el décimotercer árbol de Gide). El capricho de los reyes puede traer resultados diferentes: uno de ellos propone Quevedo:

Al tronco en que fijada su testa fuere, honor del monte y prado... tal letra escribirán al caminante. . .114

y don Gómez de Tapia contempla otro, diverso:

mil casos por Poetas celebrados en las verdes cortezas esculpían. . . ${ }^{115}$

dotando a los árboles reales con escenas de la historia de Píramo y Tisbe y la de Procne y Filomela ${ }^{116}$. Menos caprichosamente suntuaria, y mucho más usual, es la costumbre de marcar los árboles para señalar itinerarios en los sitios montuosos ${ }^{117}$; y el otrora utópico deseo de Marvell:

Fond lovers, cruel as their flame,

Cut in these trees their mistress' name:

Little, alas! they know or heed,

How far these beauties her's exceed!

Fair trees! wheres'e'er your bark I wound,

No name shall but your own be found ${ }^{118}$,

se ve hoy cumplido en el Jardin des Plantes y algunos otros lugares de París, donde cada árbol que lo merezca ostenta su tarjeta de visita con el nombre de su familia, en vulgar y en latín, y hasta su documento completo de identidad ("Plantado por... en 17..."). Las inscripciones, grabadas o afrjadas, van de la mortalidad al comercio: 
La señora [que llora a su hijo muerto] contempla arrobada el bosque y el monje [que la ha conducido allí para consolarla] escribe sobre un tronco: "A tus ojos, Señor, son años ciento - lo que un fugaz, efímero momento", y se abstrae meditando el prosaico dístico [y así quedan cien años] $]^{119}$.

Y no letras, sino estrictos letreros que piden moralidad en la conducta y decoro en el vestir, figuran en la Historia prodigiosa de Bioy Casares, pp. 88-89 de sus Historias fantásticas. Y

À la maison forestière de Villebon, les mots "lait, fleurs", étaient cloués au tronc d'un des grands cèdres ${ }^{120}$.

Agrandada, o anulada por el crecimiento vegetativo, la inscripción parecería correr menos riesgos si se la reemplaza por aditivos que enriquezcan el árbol sin dañarlo ${ }^{121}$, y con suerte similar a la del sabio rey Salomón, a la del Virgilio medieval, a la de la tumba del profeta y a la del Quevedo tradicional, una canción de Bartolomé de Segura nos suspende, indecisos, con su "colgaros" y su "por corteza":

Parad, canción que quiero aquí colgaros siquiera por corteza deste tronco. . .122

Estamos ya camino, con esta escritura sacada del árbol, de la escritura a secas y sin más: todos los que se ocupan de la historia material de las letras recorren una idéntica senda:

Despues [de escribir en las hojas de la palma] escriuierōen cortezas de arboles, señaladamente en aquellas, que facilmente se despiden del arbol: como de alamo blāco, y de platino [sic] y fresno, y de olmo.

Otros dizen, que escriuian en pieles de animales... otros que en hojas de arboles... otros, que en las cortezas dellos, como se entiende, segun lo trae el Obispo de Mondoñedo, de aquella Sibila Delphica, quando dio al Rey Romulo catorze letras escriptas en cortezas de arboles, q̀llamauā lonias, que fueron las que primero se vsaron, con el consentimiento tacito de las gentes (como lo declara Plinio) hasta que Nestor, y el Capitan Diomedes descubrieron las demas, a cumplimièto de veynte y dos que ay en el alphabeto.

Les anciens avoient deux manières de former les caractères de l'écriture; l'une [opuesta a incidendo] était pingendo, en peignant les lettres, ou sur des feuilles d'arbres, ou sur des peaux préparées, ou 
sur la petite membrane intérieure de l'écorce de certains arbres; cette membrane s'apèle en latin liber, d'où vient livre... ${ }^{123}$

Según Jardiel Poncela, todavía Charles Lummis, historiador de los conquistadores españoles del siglo XVI, "escribió el original de su libro sobre trozos de cortezas de árbol previamente lijadas por su propia mano, hasta darles delgadez de hojas de papel, advirtiendo que lo hacía porque exigía un esfuerzo de tal magnitud, la magnitud de las hazañas que había de contar en su libro" "124. La corteza separada no sólo sirvió de papel, sino que sirvió incluso de papel moneda ${ }^{125}$. Y es un eglógrafo, en fin, quien

. . hoy procura

de las cortezas al metal, y luego

al papel confiar aquellos cantos

con que sonar hacía

los patrios montes y nativos valles... ${ }^{126}$,

paso que nos lleva a nuestro cotidiano desempeño de la escritura.

Desempeño que comienza, evidentemente, por su aprendizaje, cuando el incipiente e insipiente escribidor prueba su saber y su autonomía en cuanto material le cae bajo la mano provista del instrumento respectivo. Lo sabemos muy bien, mis compañeros de la escuela primaria y yo: la cauta providencia de nuestros maestros dedicaba el último día del curso, en que debíamos aportar papel de lija con una muñeca de nueces descascaradas, a alisar y luego lustrar los pupitres fatigados de manchas e inscripciones durante todo el año escolar ${ }^{127}$. Para consolación de mis condiscípulos y mía, he ido recogiendo una rápida antología de este uso (¿uso, o mal hábito?) en mis dos domicilios lingüísticos:

... une longue table toute déchiquetée par les noms et les dessins qu'y traçaient avec leurs canifs les écoliers auxquels mon père apprenait à lire, à écrire et à compter ${ }^{128}$.

En voilà pour des années. Un couloir sans fin, tout suintant et gluant. Une porte au judas vitré, un pion morose:

- Mettez-vous là.

Je me mets là. Il y a des noms gravés sur le chêne de la table, des noms usés par les coudes et les cahiers, avec des prénoms hors de mode, des noms de vieux lycéens, morts depuis longtemps ${ }^{129}$.

J'ai écrit sur mon pupitre une sentence de H[enri] B[eyle]: "La société ne paie que les services qu'elle voit"'130. 
Au cours de l'été [1928], je fis un pèlerinage à l'École de Harrow, où je vis le nom de Byron gravé par lui dans la boisserie de chêne. . . ${ }^{131}$

J'écrivis, un soir, avec application, dans un coin de la petite table sur laquelle je travaillais à la maison [al salir de la fábrica de calzado], ces mots, comme un engagement solennel avec moi même et l'univers: "Vive le bachot!" Ce ne fut pas facile. La table était cirée et l'encre prenait mal. Je dus repasser plusieurs fois dans les mêmes traits. Enfin ce fut fait, et pendant deux années, j'eus sous les yeux ces mots stupides qui relançaient ma passion ${ }^{132}$.

.. ."La tiédeur des vieilles gens", soupire La Rochefoucauld. J'en étais loin quand j'enseignais le français en troisième, au lycée Janson-de-Sailly! Un élève avait gravé au couteau, sur un banc: "Guth, cinglé de littérature!"'133

Elle ["Jeanne de Requeville, la plus célèbre des fans de Valentino"'] a gravé le nom de Ruddy dans le bois de son pupitre. . . 134

El uso - bueno o malo-, comprobado por grandes y pequeños nombres, va también consagrado por los modernos lexicógrafos que se ocupan de la vieja retórica:

... de simples graffiti, comme on en trouve sur les bancs d'écoliers ou dans les toilettes publiques... ${ }^{135}$
Sur mes cahiers d'écolier
Sur mon pupitre et sur les arbres
Sur le sable et sur la neige
J'écris ton nom

Sur toutes les pages lues

Sur toutes les pages blanches

Pierre sang papier ou cendres

$J^{\prime}$ écris ton nom ${ }^{136}$

En las letras de mi país la cosecha no es menos opima:

.. . las sillas y las mesas [...] confesaban, sin ser interrogadas, que la ocupación de su dueño era, ó había sido, la de enseñar muchachos quienes lo primero que aprenden es el modo de sacar astillas de los asientos, y escribir sobre las mesas con el cortaplumas, ó con la tinta derramada ${ }^{137}$. 
Tenían los bancos profundas incisiones; desvergüenzas de los estudiantes, cortajeadas en la madera con ayuda de sus navajas de bolsillo; otras escritas o garabateadas con lápiz en la pared, a la altura de la mano; insolencias, injurias contra maestros, versos en boga, canciones sucias, de esas que suelen andar de boca en boca en las eternas corrientes de la humana estupidez ${ }^{138}$.

Solo su alma, en la mesa de entradas, se lo pasaba escribiendo el nombre de Lita en la mesa y en el papel secante ${ }^{139}$.

. . . aquella clase de química, perdida en un sótano, llena de bancos labrados por muchas generaciones de estudiantes. . . ${ }^{140}$

Para la clara novia que en su banco, bandera de amor, dejó bordadas nuestras dos iniciales. Quince años. Hacia octubre, bajo los delantales su pecho recitaba toda la primavera ${ }^{141}$.

Podría objetarse que media harta distancia entre los escolares, más o menos adelantaditos, que garrapatean su escritorio, y el afán amoroso de decorar con nombres, cifras y corazones y estelas versificadas las cortezas de los árboles. Nada más similar, sin embargo, como lo manifiestan, en ambas lenguas, una conocida novela y un gran poeta:

Arlette. Que de douces promenades vous ferez ensemble dans les chemins creux! Vous graverez vos prénoms dans l'écorce des arbres. . Comme ça, tenez... (Elle écrit avec de la craie au tableau noir: $V$ et $M$ et elle dessine un coeur percé d'une flèche $)^{142}$.

Como en los troncos vivos de los árboles de las aulas así en los muertos troncos grabó el amor por manos juveniles su eterna empresa ${ }^{143}$.

Se cierra así en los muertos troncos, atemporal uroboro de la eterna empresa que partió de los troncos vivos de los árboles, este periplo no excesivamente variopinto en torno de un topos que es (se lo repite una vez más) expresión o exasperación de un impulso tan inconteniblemente profundo como profundamente incontenible, ya nazca de la apetencia por consolidar una personalidad como del empeño por proclamarla, ya sea brote de la pasión más profunda, jubilosa o dolida, o ya surja del simple deseo — no siempre consciente- de abandonar un mensaje sin contenido ni des- 
tinatario precisos. Así un poeta (en quien la frecuencia de notar estas manifestaciones es casi obsesiva), admite que

...ni en un árbol, ni en una piedra, ni en la tierra, donde a veces dibujo, grabé uno solo de mis pensamientos ${ }^{144}$.

En su alabanza de alguien que tanto enseñó con su ejemplo y con la liberalidad de su saber, y cuyo nombre aparece aquí con obligada frecuencia, mi maestro Marcel Bataillon escribió que María Rosa Lida de Malkiel supo unir felizmente al estudio de estas expresiones recurrentes la indagación de la diferencia que sus sucesivas reapariciones acusan, mostrando cómo esas mínimas -inmensas- diferencias acusan, a su vez, el impacto obligado de personalidades y movimientos disímiles ${ }^{145}$, en vez de ser - como la proliferación de los mensajes amorosos "escritos en cortezas por pastores" - simples ingredientes de estilo, casi síntomas de una especie de contagio literario. Así, un lúcido estudio sobre las críticas formuladas en torno de la obra de Borges opone a la indiscutible personalidad de éste un trozo de una exitosa novela que repite, vulgarizándolo en clave existencialista, el final de otra novela exitosa anterior ${ }^{146}$. Por el contrario, un escritor (al que Borges, precisamente, calificó como "el único poeta argentino sospechoso de genio") se sirve -ignorándolo, fiado solamente del impulso general que nos mueve- del topos que (quizás demasiadamente) hemos sobrevolado y le impone su sello, soldando en él los dos extremos opuestos de las inscripciones amatorias:

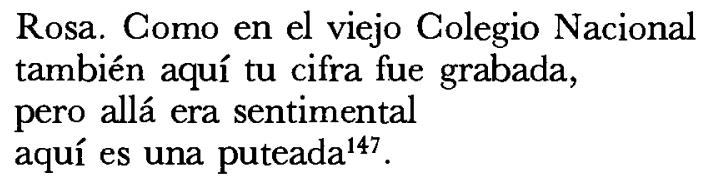

No se trata aquí de una "existencialización" mimética: el libro que contiene estos versos se imprimió cuando existencialismo y existencialistas estaban en el seno del limbo, antes de pasar al de Abraham. Y acaso el rememorar esta libertad, única dentro de una exasperante uniformidad sentimental, justifique todo este enfoque, si es que algo pudiera justificarlo. 


\section{NOTAS}

1 Julián Marías, "Pintadas", $A B C, 14$ de agosto de 1987: indicación que debo a la gentileza de Beatriz Elena Entenza de Solare. La expresión política se roza frecuentemente con la literatura, incluso en los graffiti: NiNO FRANK (10.7.2 et autres portraits, Maurice Nadeau/Papyrus, Paris, 1983, p. 230), recuerda lo que le costó, en la Italia de entre las dos guerras, publicar un cuento de Ilya Ehrenburg que mencionaba "des Vive Lénine inscrits sur les murs des call," venecianas.

2 ERnest ERNest, Sexe \& graffiti, Alain Moreau, Paris, 1979; la forma empleada en el título, "graffiti", es la correcta, según Littré. Respetamos, sin embargo, las grafías disímiles de otros escritores. Algunos reputados literatos no desdeñan recordar tales inscripciones: según JEAN COCTEAU, la memoria suele llevarse bien con la interpretación psicoanalítica: "La Clef des Songes la conforte en cela qu'elle couvre les murs des graffiti obscènes que l'oeil a coutume de voir partout"' (Journal d' un inconnu, Bernard Grasset, Paris, 1953, p. 158). También Jean Paulhan, hablando de una criada que las circunstancias habían emancipado, anota: "Menée par je ne sais quel scrupule, elle usait pour elle - tout en se plaignant d'y lire plus d'une inscription de mauvais goûtdes cabinets du fond de la cour, qu'elle n'appelait pas cabinets mais chiottes", ("Un nouveau train de vie", p. 24 de Les causes célèbres, NRF-Gallimard, Paris, 1950). Sobre la proliferación y transfiguración de este tipo de pintadas que en el artículo homónimo se pasan por alto, véase el comienzo de otro, aparecido en Le Figaro Magazine del 17 de octubre de 1987, p. 148, firmado por FraNÇOIS LEBRETTE: "Autrefois, les graffitis restaient cantonnés aux urinoirs. Voilà qu'ils fleurissent aujourd'hui sur l'écran du Minitel, promu au rang de vespasienne électronique".

${ }^{3}$ Cito por la $\mathrm{I}^{\mathrm{a}}$ ed. de sus Impresiones y paisajes, Granada, 1918, p. 130.

4 Jean-Pierre Dorian, “Buttes Chaumont", Écoute le temps, Albin Michel, Paris, 1980, pp. 156-157. A veces las inscripciones cobran, siendo de segunda mano, un cierto carácter votivo: “G'est l'ancien coin du Puits d'amour où tous les amoureux des siècles passés allaient pieusement graver leurs noms en mémoire d'une pauvre fille qui s'y était jetée, il y a bien longtemps' (Gustave Lenôtre, Notes et souvenirs [editado por su hija Thérèse), Calman-Lévy, Paris, 1940, p. 97).

${ }^{5}$ Falto del texto original, retraduzco un pasaje de "La Liberté éclairant le mort" ["The corpse in the statue of Liberty"] de WILLIAM IRISH, incluido en su Couleur d'épouvante, Presses Pocket, Paris, colaborando detectivescamente con el traductor francés anónimo.

${ }^{6}$ Por idéntica razón, me sirvo de la traducción francesa de The hollow (AGATHA Christie, Le vallon, Librairie des Champs Elysées, Paris, pp. 202 y 373).

${ }^{7}$ Ignacio G. Anzoátegui, Vidas de muertos, t. 1, Megáfono, Buenos Aires, 1934 (hay reed.); cf. Satie, Regrets des enfermés (Jonas et Latude) y Luigi Dallapiccola (autor también, sobre sus Canti di prigionia, de la ópera Il prigioniero).

${ }^{8}$ Dumas describe también los graffiti de la celda de los condenados a muerte en la prisión de Bicêtre: "Les murs, noircis par le temps et par la fumée, étaient rayés de tous côtés par les noms que les hôtes successifs de cette terrible demeure avaient inscrits à l'aide de leurs fers peut-être. Un d'eux, d'une 
imagination plus capricieuse que les autres, y avait tracé l'image d'une guillotine" (Gabriel Lambert ou Le bagnard de l'Opéra, Éds. des Autres, Paris, 1979, p. 153); más adelante (p. 159) reincide: “. . . ces murs, couverts de noms de gens qui ont vécu comme il vit dans ce moment, et qui le lendemain étaient morts". COCTEAU (loe. cit.) sostiene que el hombre "craint jusqu'à la poésie, depuis qu'elle grave des insultes sur les murs de notre cachot", y más lejos (p. 178) que prisioneros en el sueño "Nous nous cognons contre des murs recouverts de phrases écrites".

9 Texto citado en la sección Poésie, de Jean Orizet (Le Figaro Magazine, 23 de mayo de 1987, p. 47).

10 Rodríguez Marín, Cantos populares españoles, t. 2, p. 297, núm. 2577; en la p. 389 anota la variante "en contar los eslabones/ que mi cadena tenía". El núm. 2577, sin variantes, figura en las Mil coplas de jota, de J. J. JimÉNEZ DE ARAGón, p. 329, núm. 15 B; el cancionero de Eusebio Vasco, Treinta mil cantares populares, Valdepeñas, 1929, (t. 3, p. 323, núm. 5320) varía: “en lo que me divertía", como Jiménez de Aragón, p. 368, núm. 14 A.

${ }^{11}$ Eduardo Galeano, La canción de nosotros, Sudamericana, Buenos Aires, 1975 , p. 174.

12 Jean Giono, Voyage en Italie, NRF-Gallimard, Paris, 1953, p. 17. El citado libro póstumo de Gustave Lenôtre consigna otro ejemplo de esta ocupación de soldados semidesocupados: en una conversación con la emperatriz Eugenia, registrada el 21 de enero de 1906, ésta evoca sus precisos recuerdos topográficos de las Tullerías, destruidas un cuarto de siglo antes: "elle m'a parlé des deux terrasses sur lesquelles on a bâti sur l'une, du temps de LouisPhilippe, le grand escalier, et plus tard, sur l'autre, ses appartements. Elle m'a dit que, sur cette dernière terrasse, avant qu'on ne construisît ses appartements, les pierres étaient couvertes de noms gravés au couteau, de gens ayant monté la garde"' (pp. 157-158).

13 ANNa de Noallees, Le livre de ma vie, Mercure de France, Paris, 1976, p. 88. Poseo un tomito de canciones de Béranger, recibido por el padre de Paul Dukas como premio por su actuación de orfeonista; el compositor lo ha llenado, literalmente, con la repetición obstinada de su nombre: Dukas, $\mathrm{Du}$ kas, Dukas, en muchas páginas y repetidas veces en muchas de ellas.

${ }^{14}$ Manuel Polo y Peyrotón, Costumbres populares de la Sierra de Albarracín, pról. Fernán Caballero, $3^{a}$ ed., Tipografía Católica, Barcelona, 1876, p. 366.

15 Jean Cocteau, "Mes", en Poésie (1916-1923), NRF, Paris, 1925, p. 337.

16 Pruebas al canto. Paredes: en el vasto palacio abandonado, "Sur le mur de la salle de garde ils [los gitanos] ont gravé au couteau una grande nef symbolique chargée de tous leurs morts et qui vogue, proue en avant, vers la petite sentine pleine de paille où la bouchère des Quatre coins donne ses rendezvous d'amour." (Jean Giono, Présentation de Pan, Grasset, Paris, 1930, p. 23); "En el centro polvoriento de la ciudad, al mediar el girón lea, hay una casa de balcones y celosías cuyas paredes maculadas por el tiempo y los incultos transeúntes (manos sentimentales que graban flechas y corazones y rasgan nombres de mujer, dedos aviesos que esculpen sexos y palabrotas) dejan ver todavía [el color añil]." (VARgas Llosa, La tía Julia y el escribidor, Seix Barrai, Barcelona-Caracas-México, 1978, p. 251. Ya en la Lima colonial había causado escándalo una inscripción similar a las últimas, con la leyenda: "De esta capa nadie escapa"; lo relata Ricardo Palma, en sus Tradiciones peruanas); "Sou- 
dain, en face de moi, sur le mur, au bas d'un dessin obscène, un prénom..." (Marcel Arland, Antares, $2^{\mathrm{e}}$ éd., NRF-Gallimard, Paris; p. 151). Paredes, puertas, celosías: “. . Faut-il lui parler du dictionnaire de médecine? Et des dessins que j'ai faits au charbon sur la porte de la grange? “(MARCEL ARLAND, Terre natale, NRF-Gallimard, Paris, 1938, p. 244); “. . . les figures et les noms gravés le long des murs, des volets et des portes..." (MARGEL JouHANDEAU, Astaroth, NRF-Gallimard, Paris, 1929, p. 98). Herrera, al afirmar "No gravaré en colunas vuestra istoria" ("Elegía I", v. 349, p. 24 en Poesías, ed. V. García de Diego, Espasa-Calpe, Madrid), indica que había quienes lo hacían; y ya lo apunta Horacio: ". . . Pero ser razonables los Poetas/ no lo afirman los Dioses, ni los hombres,/ ni las columnas, si les pegan versos." (Arte poética, trad. Vicente Espinel, en el Parnaso de Sancha, t. 1, p. 23). Entre las vacuidades que Julien Green intercambia con Jacques Maritain, nos transmite la interesante noticia de que ni las vigas del techo suelen permanecer incólumes: 'Jusqu'en 1906, la maison [de campagne de Faverolles], qui est assez ancienne, était le presbytère d'une belle et fort vieille église dont on répare la voûte en ce moment (j'entends le bruit que font les menuisiers avec leurs marteaux; la voûte en berceau était de châtaignier, on y a trouvé le nom d'un des ouvriers et une date, 1560: à présent le châtaignier, qui coûte cher, est remplacé par du sapin, qui durera moins longtemps, mais les trous seront bouchés - pourquoi est-ce que je vous raconte tout cela?" (Une grande amitié. Correspondance 19261972, Pion, Paris, 1979, p. 157; la cita corresponde al Martes Santo de 1964. Hasta los vidrios reciben su mensaje: "Parfois, comIne Dominique [alude al cap. 2 de Dominique de Fromentin], il grave sur les boiseries et sur les vitres de sa chambre des signes qui lui rappellent ces événements de la vie du coeur" (Pierre Kohler, "Introduction" a Adolphe de Benjamin Constant, Spes, Lausanne, 1921, p. 51: casi como los "joyeux lurons" que describe GERALD DURRel, "déterminés à montrer à leur petite amie que le diamant de leur bague est authentique, en gravant leurs initiales dans le verre", L'arche immobile, Stock, Paris, 1977, p. 75; cf، “c'est Byron qui est venu ici [à Cintra]; il a écrit son nom sur une vitre; il était sûr de lui", JaCQUes CHARDOnNe, Matinales, Albin Michel, Paris, 1956, p. 193). Los muebles exhiben su contribución, en la guerra como en el amor: "Une compagnie américaine, officiers et soldats, vécut là deux mois, jouant au football dans la galerie de l'étage et gravant dans le bois des lits, de la pointe du couteau, les noms et les dates qui leur étaient particulairement chers. En cela rien que de naturel!" (SIMONE, Ce qui restait à dire, NRF-Gallimard, Paris, 1967, p. 83. Lo mismo, con menos filosofía los ocupantes son distintos- en ROLAND DORGELÈs: "Mes manuscrits, mes livres, tout est resté làbas, dans ina maison des champs. Au creux d'un val tranquille où le vainqueur campe aujourd'hui, gravant peut-être des croix gammés sur le plateau blond de ma vieille table" (La drôle de guerre 1939-1940, Albin Michel, Paris, 1957, p. 290); “Disimulaba la abertura un biombo de cartón, constelado, como los cuartos de baño de los lugares públicos, de palabrotas y dibujos obscenos" (VARGAS LlOSA, op.cit., p. 437); “ “. j' ai gravé mes initiales sur la table de plusieurs cafés..." (LySANDro Z. D. GalTiER, "Buenos Ayres" en E. GonZález LANUZA, Cuando el ayer era mañana, Sudamericana, Buenos Aires, [1954], p. 50). Las tumbas, en fin: "Frente a ese antiguo cementerio me iba transformando en una tumba solitaria en la que probarían sus cortaplumas los muchachos ociosos" (SANTIAGo DABOVE, "Ser polvo" en 
20 ficciones, p. 54). Y para terminar, la cúpula: el barón de Géromb "a fait parler de lui à Rome où il a escaladé au risque de se rompre vingt fois le cou la boule de bronze qui domine la coupole de Saint-Pierre. Tout ça pour y graver son nom" (LOUIS PAUwels, "Le baron de Géromb", en Nouvelles histoires magiques, pp. 230-231).

${ }_{17}$ Silvina OCAMPO, "Tales eran sus rostros" en Mi mejor cuento, Orión, Buenos Aires, 1973, p. 198; cf. p. 199: “ . . Fabia Hernández [ . . ] visita el viejo edificio y contempla los nombres de los alumnos escritos en las paredes (inscripciones por las que los reprendían)".

18 Vulpian de Moussy, Miguel d'Oléa, Flammarion, Paris, 1897, p. 230.

${ }^{19}$ Las fuentes del Romancero general, ed. Rodríguez-Moñino, t. 3, f. 10.

${ }^{20} I d$, t. 6,257 y t. 8,14 ; cf. t. 2,120 ss.

21 Ramón Caballero [Rubio], Gorjeos del alma; cantares populates, Hernando y Cía., Madrid, 1884, p. 91.

${ }^{22}$ Camprodón, Flor de un día, B. Gil, Lima, 1873, p. 42.

23 Benito Pérez Galdós, Gloria, Losada, Buenos Aires, 1945, t. 2, p. 40.

${ }^{24}$ ACHILle FOUQUIER, Chants populaires espagnols, Librairie des Bibliophiles, Paris, 1882, p. 71.

25 J. J. JIMÉnEZ DE ARAGón, op. cit., p. 120, núm. 40. La expresión merece un ligero examen. Por una parte, como en Galdós y en Keats, es una figuración de lo efímero: el refranero inédito de Carmela Saint-Martin, la excelente cuentista pamplonica, equipara "agua (escribir en el): “no dejar constancia de lo escrito"", con "polvo (escrito en el): "escrito en el agua", en la arena, algo sin consistencia que se borra enseguida". La idea de levedad prevalece en el distingo que GERARDo Diego establece entre los dos Machado: "Manuel, por el contrario, parece que juega, que traza en el agua, que dibuja en el aire": levedad no exenta de peso y precisión (Manuel Machado, poeta, Editora Nacional, Madrid, 1974, pp. 18-19). A su vez, Mora Guarnido pone el acento en la inutilidad del gesto: considerar qué destino hubiera sido el de García Lorca si se hubiera dedicado a la música "sería como ponerme a trazar rúbricas en el agua"' (Federico García Lorca y su mundo. Testimonio para una biografía, Losada, Buenos Aires, 1958, p. 87). Los viejos lexicógrafos francoespañoles dan un sentido peculiar a esta expresión, que Billet tacha (poniéndole un asterisco) de vulgar: "hazer vna Cruz en el agua, ité, "hazer vna raya en la pared, faire la croix à la cheminée" (p. 191, y 241 en la parte francésespañol: el Dictionnaire françois et italien de Oudin continuado por Veneroni (1707) da para la locución francesa el equivalente italiano "fare la croce col carbone bianco"); Texeda (p. 294) registra la forma corriente y la explicación exacta: "Hazer raya en el agua, Chose extraordinaire". La locución, que falta en el Registro de Romera Navarro, la explica correctamente Cejador en su ed. de La Celestina (Espasa-Calpe, Madrid, 1913, t. 1, p. 141, nota a la línea 11) con varios ejemplos de Correas y a propósito del parlamento de Elicia: “ “Santiguarme quiero, Sempronio! ¿Quiero hazer vna raya en el agua! ¿Qué nouedad es esta, venir oy acá dos vezes?"

${ }^{26}$ Rubén Darío, Poesías completas, ed. Méndez Planearte, p. 834; André Gide-Paul Valéry, Correspondance (1890-1942), NRF-Gallimard, Paris, 1955, p. 223; Bernard Glavel, Écrit sur la neige, Stock, Paris, 1977, p. 206. En carta a Paul Claudel ("Ce 27 janvier 1929") la princesa Marthe Bibesco da testimonio de un entusiasmo acrecentado: “Cet après-midi j'ai couru au Bois, sur 
une couche de neige mince, dans une allée presque solitaire. Quelqu'un avait écrit sur le bord de l'allée, ceci, en toutes lettres: "Vive la neige!" (Échanges avec Paul Claudel. Nos lettres inédites, Mercure de France, Paris, 1972, p. 143).

${ }^{27}$ Las únicas palabras que Jesucristo escribió las trazó con el dedo en la tierra (San Juan lo narra y lo repite: cap. 8 , versículos 6 y 8 ): pero más que expresión de lo fugaz, su acto refleja la oposición entre la enseñanza oral (que es eminentemente la suya) y el escrito (hay remisión al rico libro de mi maestra Solange Corbin sobre este punto en mi Introducción al estudio de Don Juan Manuel..., Castalia, Madrid, 1972, p. 255). Y no es de excluir el elemento milagroso que Selma Lagerlöf desentraña en uno de sus bellos relatos evangélicos, basados principalmente en los textos apócrifos: cada uno de los acusadores de la mujer adúltera lee la relación de sus propios pecados en lo escrito por Jesús en el polvo.

28 "Silva segunda" en Obras varias, ed. J. Simón Díaz, CSIC, Madrid, 1954, pp. 230-231.

29 Bartolomé Ximénez Patón, Eloquencia española. . E En Toledo, por Thomas de Guzmā, 1604, f. 89 (ejemplo de "Exclamación").

${ }^{30}$ Fuentes..., t. 11, f. $104 \mathrm{v}^{\mathrm{o}}$.

31 Ibid., t. 10, f. 26.

32 Eusebio Vasco, op. cit., t. 3, p. 333, núm. 5373.

${ }^{33}$ Las citas de PIERre Loư̈s se hacen por la I ${ }^{\mathrm{a}}$ ed., semianónima: Les chanson de Bilitis. Traduites du grec pour la première fois par P. L., Librairie de l'Art Indépendant, Paris, 1895, con la dedicatoria a André Gide, fechada el año anterior: una tajante apreciación del autor y sus dedicatorias puede encontrarse en ei Journal de Gide; "La pluie au matin", núm 96, ocupa la p. 123.

${ }^{34}$ Cancionero de cosas de amor, ms. de 1575, en J. CEJADOR, La verdadera poesía castellana..., t. 9 , p. 128 , núm. 3415 .

35 Fuentes. ., t. 3, f. $150 \mathrm{v}^{\circ}-151$. El verso final de nuestra cita se lee en la Diana de Montemayor: "Sobre el arena sentada/ de aquel río la vi yo,/ do con el dedo escribió/ "antes muerta, que mudada»./ Mira el amor lo que ordena,/ que os viene a hacer creer/ cosas dichas por muger/ y escritas en el arena", citado por H. A. RENNERT, "The Spanish pastoral romances", $P M L A, 7$ (1892), p. 14.

${ }^{36}$ Gallardo, Ensayo de una biblioteca española de libros raros y curiosos, t. 1, cois. $1205,1223$.

37 TrRso de Molina, Amar por arte mayor, en Obras dramáticas completas, ed. Blanca de los Ríos, Aguilar, Madrid, t. 3, p. 1181.

${ }^{38}$ Antonio Fernández Molina, "El río" en $M N$, 1966, núm. 1, p. 50.

39 "Fortuna española de un terceto en la Arcadia de Sannazaro", pp. 100 ss. de sus Relaciones hispanoitalianas (véase la nota 89). Cf. "Solco onde e'n rena fondo e scrivo in vento" (Petrarca, Il Canzoniere, $2^{\circ}$ ed., Ulrico Hoepli, Milano, 1908, "con le note di Giuseppe Rigutini riprese ed accresciute da Michele Scherillo", CGXII, v. 4, p. 269; la p. 270 anota: "Solco onde. . A Azioni vane. Catullo, 70, 4: "In vento et rapida scrivere [oportet] aqua»"); FuciLla, pp. 100-101, cita a Petrarca y a Catulo. En su obra monumental (Literatura europea y Edad Media latina, F.C.E., México, 1955, p. 426 y nota 4) Curtius reúne ejemplos de Platón y Sófocles, el de Catulo, otros de San Agustín y Shakespeare, y el epitafio de Keats; Fritz SCHALK, en su reseña a la antepublicación de su Schrift- und Buchmetaphorik in der Weltliteratur, sobretiro de Deutsche 
Vierteljahrsschrift für Literaturwissenschaft und Geistergeschichte, 1942, reseña aparecida en $R F, 57$ (1943), 136-143, agrega el conocido pasaje de La Dorotea ("escriuir en el agua/ la fe del amor pasado", p. 241 de la ed. de Américo Castro); a ambos puede recordarse el título de la novela que valió a Francis de Miomandre el Prix Goncourt: Écrit sur de l'eau.

40 La primera cita corresponde a la "Égloga amorosa" de LOPE DE VEGA, según $B A E$, t. 38, pp. 307 ss.; la vieja atribución a FRANCISCO LÓPEZ DE ZÁrate, que figura en el Parnaso de Sancha (t. 8, pp. 173-187) se ve refrendada en la ed. de José Simón Díaz con el mismo título de "Égloga amorosa", pp. 12 ss. La segunda cita se toma de las Poesías líricas, ed. J. F. Montesinos, Espasa-Calpe, Madrid, t. 2, p. 32. Esta opción fitoglífica figura ya en la Arcadia de Sannazaro: Logisto proclama a los que quieran saberlo: "Chi vuol udire i mie suspire in rime.../ lega per queste quercie e per le sassi,/ che n'è già piena omay ciascuna valle" (ed. Scherillo, Ermanno Loescher, TorinoFirenze-Roma, 1888, p. 67). Se lee en Herrera: "en árboles y peñas esculpido/ el nombre de la causa de mi pena/ onro con mis suspiros y gemido" ("Elegía V", vv. 1941-1943, p. 109 de la ed. de García de Diego); se lee, repetidamente, en las Poesías de GóNGORA presentadas por Gallardo en el t. 4 de su Ensayo: "En estas duras plantas/ impresas podrás ver, y en estas peñas,/ cuántas han sido y cuántas/ de tu desdén y de mi amor las señas..." (col. 1246), "En sus troncos o en sus peñas/ le querrá acaso escrebir. . " (col. 1248). Don Quijote prefiere una materia menos penosa: "y así, se entretenía paseándose por el pradecillo, escribiendo y grabando en las cortezas de los árboles y por la menuda arena muchos versos, todos acomodados a su tristeza, y algunos en alabanza de Dulcinea"' ( I, xxvi; en la ed. de Espasa-Calpe, Madrid, t. 2, p. 328). Las rocas solas, como menos favorables, son más raras: "en un pedazo de peña hecho a manera de padrón hallé unas letras escriptas con punta de acerado cochillo, que decían: "... Duro peñasco, en do escripto y pintado/ eternamente queda mi tormento...."' (Diana, de GaSPAR Gil Polo, en M. MenÉndez y Pelayo, Orígenes de la novela, t. 2, pp. 422-423).

${ }^{41}$ Góngora, ed. Foulché-Delbosc, t. 1, pp. 3 y 228; cf. los vv. 598-599 de la "Soledad Segunda": "Esta, en plantas no escrita,/ en piedras sí firmeza, honre Himeneo"' (ibid., t. 2, p. 108). Dámaso Alonso recalca la perdurabilidad expresada: "No escrita en cortezas de caducos árboles, como es costumbre de enamorados, sino en duras y perdurables piedras", en su edición de Las Soledades, Ediciones del Árbol, Madrid, 1935, p. 245.

${ }^{42}$ Silvina Ocampo, Autobiografía de Irene, Sudamericana, Buenos Aires, p. 164. La interlocutora se muestra más escéptica que su adorador: - “¿Cómo sabes que iremos al cielo? - le respondí. - ¿Cómo sabes que en el cielo hay árboles y cortaplumas?"

${ }^{43}$ DOMiniQue FrÉTARD, "Brazza retrouve son Savorgna", en Grands reportages, núm. 70, mayo de 1987, 76-81; la fotografía del árbol figura en la p. 79, y la leyenda va en la opuesta, p. 78.

44 Émile Henriot, Naissances, Pion, Paris, 1946, p. 233. Véase infra nota 86.

${ }^{45} \mathrm{Se}$ sabe que las sibilas escribían sus profecías en hojas de árboles que confiaban al aire: cf. Eneida, III, v. 445; lo recuerda CALDERÓn en La Sibila del Oriente, y SAAVEDRA FAJARDo equipara su mensaje a las pragmáticas incumplidas: "Respuestas son de Sibila en hojas de árboles, esparcidas por el viento" ("Empresa XXI", en Idea de un príncipe político-cristiano representada en cien 
empresas, ed. García de Diego, Espasa-Calpe, Madrid, 1969, t. 1, p. 268). Un enamorado, en la Comedia Doleria, se arroga el procedimiento: "no ay hoja en este árbol [él mismo] en que tú no estés scripta" (MenÉndez y Pelayo, Orígenes de la novela, t. 2, p. 335). GABRIEL Astruc, creador del Théâtre des ChampsElysées, lleva más lejos la identificación: "Arbre solitaire sur le bord de la route, dans mon écorce rugueuse subsistent gravés, par les vieux couteaux de jadis, quelques apophtegmes philosophiques, quelques hémistiches mutilés, quelques fantômes grecs ou latins. C'est tout qui me reste de ces belles années. Qu'on n'impute pas à la pédanterie les citations échappées à ma plume au long de ces souvenirs. Ce sont de vieilles chansons d'amour dont la réminiscence me met des larmes dans le coeur et dont le frémissement ailé se perd lentement dans les nuages de la vie"' (Le pavillon des fantômes, P. Belfond, Paris, 1987, p. 37).

${ }^{46}$ Esta acepción figurada, que ha desaparecido del diccionario usual, la alberga el de Autoridades: "Por extensión y metaphoricamente se toma por qualquiera cosa en que se escribe: como los troncos de los árboles, \&c, y tambien llaman papél el cielo, y letras ò charactéres las estrellas. Uno y otro es mui usado en la Poesía". Bastarán unos pocos ejemplos: "De algun alamo lo diga/ la corteza, que les fue/ bronce en la legalidad,/ i en la obediencia papel", (GónGORA, "Del rei y la reina, $\mathbf{n}^{\text {os }}$ señores, en Aranjuez, antes de reinar", ed. cit., t. 2, p. 332, núm. 353); " chopo gallardo, cuyo tronco liso/ papel fue de pastores, aunque rudo"' (id. , 'Soledad I', ed. cit., t. 2, p. 75, vv. 697-698); "Fresnos en cuyas cortezas,/ papel de mis pensamientos,/ escribió el alma verdades/ contra inclemencias del tiempo" (TIRSO, La fingida 'Arcadia, en NBAE, t. 4, p. 448); "Y escribí quejas y amores/ en el papel de los fresnos"' (id., "Romance CXLIV", en las Obras - A Amberes, en la emprenta palatiniana de Balthasar Moreto, 1663- ejemplar de Don Pedro Henríquez Ureña, y gentileza de María Rosa Lida); "y en el papel de un álamo escribieron/ para memoria de aquel triste día:/ Nymphas de Manzanares y pastores/ya no hay amor, que aquí murió de amores" (LOPE, "Laurel de Apolo", X, 208; como "Estancias" sueltas en el Parnaso de Sancha, t. 3, p. 13), "Publiquen essos troncos, essos ramos. . . /esse vivo papel, donde firmamos/ con juramentos penas contra oluidos" (id., "Égloga amorosa contestada", en la ed. de LóPEZ DE ZÁRATE por Simón Díaz, p. 13); "Mas fiel eres, uerde haya/ que aquella mano que viste/ en este tosco papel/ escreuir mi nombre triste..." (Fuentes..., t. 4, f. 19 , y t. $6,200 \mathrm{v}^{\circ}$ ). QUEvEDO, según acostumbra, sobrepasa lo acostumbrado, y escribe: "O vos troncos.../ seréis o en esta orilla, que el Sol dora,/ verde historia de amor, y de esta falda/ rústico libro escrito en esmeralda" ("Idilio I", en el Parnaso de Sancha, t. 4, p. 186). Tirso pone todavía más: “¿Qué tronco no es ya letrado/ a puras cifras y empresas,/ libros de la voluntad,/ del sencillo amor imprentas?" (El melancólico, ed. de los Ríos, t. 1, p. 82; cf. lo que se dice más adelante sobre la empresa del viejo Sileno (El pastor de Filida, p. 464).

47 Algunos autores mencionan simplemente el árbol, a veces sin precisar su papel: "Los árboles presento... por testigo" sugiere GARCILASO ("Canción III", en Obras completas, ed. E. Rivers, Castalia, Madrid, p. 35, vv. 26 y 28). Otros son más explícitos: "No hallo árbol adonde no escribo/ el nombre tuyo y la cuenta entera/ del mal sin causa que de ti recibo" (DIEGo Hur TADO DE MENDOZA, “Égloga II”, p. 78; “ . . pintaba con mi cañibete en los árboles que hallaba el nombre de la mi Belisia"' (Toreuemada, "Colloquio pas- 
toril" en Orígenes de la novela, t. 2, p. 673); “. . . el sacro río/ besa el nombre en sus arboles grauado"' (Góngora, "Panegírico al Duque de Lerma", ed. cit., t. 2, p. 263); "Árbol no habrá que a Febo más contente/ que el que tu nombre escrito en sí tuviere" (HERRERA, "Égloga primera, libro segundo" en $B A E$, t. 32, p. 337); "En árboles dexé scripta mi gloria", reza una canción (¿de Juan de Coloma?) en el Cancionero general de obras nuevas reproducido en L'Espagne au XVt et XVIf siècle de MoreL-Fatio (Heilbronn, 1878, p. 568, núm. $\mathrm{XCV}, 29)$. No sabría asegurar si "y los troncos, que un tiempo llamé míos,/ de sus tiernas niñeces olvidados. . ./ sepultados en ocio, yacen mudos/ de este monte a los ecos"' (Quevedo, Poesías, ed. Blecua, Barcelona, p. 426, núm. 398) responden al tema xilográfico, pero me inclino a creerlo, en vista de la abundancia de otros testimonios: "Quexandose de su Arcisa/ Lucinio el pastor lloraua/ y en vn verde tronco escriue/ estas preciosas palabras..." (Fuentes. . . , t. 3, $58 \mathrm{v}^{\mathrm{o}}-59$, y Romancero general, facsímil de Huntington, f. 62), "Testigos, troncos diversos /maltratados con sus versos"' (Tirso, Esto si. .., ed. cit., t. 2, p. 718), "otras cosas que los rudos /troncos las publican ya" (VÉ. LEZ de Guevara, La serrana de la Vera, en Teatro antiguo español, ed. Menéndez Pidal, p. 48), "en sus troncos deja/ mis ecos grabados" (TRILlo y FigueroA, "A una dama ausente" en $B A E$, t. 42, p. 68), la Minguilla de Góngora "las verdes orlas escusa/ de la fuente de los olmos,/ por no verse en sus chrystales,/ por no leerse en sus troncos" (ed. cit., t. 2, p. 343, núm. 357), "porque con este hierro, que algún día/ ha de dar fin a mi cansada vida/ en este tronco escriba mis querellas" (FIGUeroA, "Égloga a Tirsi"), "ni el cielo borre/ de aquestos troncos lo que al tiempo escribes" (EsQuilache, "Égloga III": su texto y el de Figueroa los debo a la gentileza de María Rosa Lida), y, tras recordar algunas metamorfosis - Dafne, Jacinto- "sólo de Amor las glorias/ conservan en los troncos las memorias" (FARIA y SouSA, "Canción amorosa V", t. 3 de sus obras - edición de 1646, f. $9 \mathrm{v}^{\circ}$ ). Si alguien especifica "en la corteza del tronco/ estas palabras estampa"' (Fuentes. .., t. 1, f. 123, y t. 2, f. 39): cf. "Probaron en el campo su destreza/ Dïana, Amor y la pastora mía,/ flechas tirando a un árbol, que tenía/ pintado un corazón en la corteza" (GIL Polo, Diana, ibid., p. 480), prima la simple mención de la corteza: "Mira si sera tristeza,/ no uerte, y uer este prado,/ de arboles tan adornado,/ y mi nombre en su corteza,/ por tus manos señalado..." (Montemayor, La Diana, en Orígenes..., t. 2, p. 330), "si escribí tu amado nombre/ en estas cortezas lisas/ de estos árboles" ("Romance anónimo" en $B A E$, t. 10, p. 271), "Tu nombre en las selvas miro,/ y estan mucho mas contentas/ con el que no con sus ramas,/ escritas tantas cortezas"' (PINTO DE MORALES, Maravillas del Parnaso y Flor de los mejores romances, facsímil de Huntington, f. $33 \mathrm{v}^{\circ}-34$ ), “¿Quién, pues, verdes cortezas, blanca pluma/ les dio?" (GónGORA, "Al Phaeton del conde Villamediana", ed. cit., t. 2, p. 261), "Fragoso monte, en cuio basto seno/ duras cortezas de robustas plantas/ contienen aquel nombre en partes tantas.../ las cortezas do estan desnuda, o viste/ su villano troncón de yerba verde,/ de suerte que mis ojos no la vean" (id., t. 1, p. 45, núm. 30, "En la muerte de una señora que murio moça en Cordona": texto que autorizaría a dotar de idéntico senticlo al del t. 2, p. 340 , núm. 356, "El monte lo calle,/ cuios troncos no/ visten por corteças/ pieles de león"), "En cuyas tiernas cortezas/ es devorador prolijo/ de mi pecho el doro nombre/ de Fili, en ellas escrito" (TRILLO Y FIGUEROA, "Romance XXVI", en BAE, t. 42, p. 81), "aquellos altos 
versos en amores/ por ti en ardientes fuegos fabricados/ y escriptos en cortezas por pastores" (URREA, "Epístola a Cetina" en Gallardo, op.cit., t. 2, col. 435), "Cortezas hay donde escriben/ los amantes cuanto quieren" (LOPE, El sembrar en buena tierra, en Obras escogidas, t, 1, p. 1152), "ya no escribiré hermano sino esposo,/ por las cortezas de los verdes árboles", (El remedio en la desdicha, en $i b i d$, , t. 1, p. 75 y t. 2, p. 1510 [!]), "su nombre en la corteza/ vuestra extendiendo..." (Herrera, "Canción VII", BAE, t. 32, p. 296, y "Canción III' en Obra poética, ed. Blecua, Real Academia Española, Madrid, p. 256, vv. 64-65), "Plantas, cuyas cortezas/ ilustré con el nombre de Crisalda"' (PEDRO DE EsPINOSA, en BAE, t. 42, núm. 27 de sus Flores): la amada de Espinosa - siguiendo el ejemplo que le viene de Garcilaso: "apartada algún tanto, en la corteza/ de un álamo unas letras escrebía", "Égloga III", en Obras, ed. Navarro Tomás, Espasa-Calpe, Madrid, p. 133, vv. 237-238 —durante la ausencia del poeta "había dado al viento su nombre amado y grabádolo con el propio suyo en la corteza de los árboles"' (Rodríguez Marín, Pedro Espino$s a$, p. 190). Figura poco el resto de la anatomía: "Publiquen esos troncos, esos ramos" es verso de la disputada "Égloga amorosa" de LOPE o LÓPEZ; el romancista anónimo de las Fuentes (I y II, ya citado) se anda también por las ramas; y un pastor de los de Fílida apostrofa a un "seco tronco", que fue en otro tiempo "fresno umbroso": "Ya me acuerdo de ver una figura/ que estaba en tu cogollo dibujada/ de la que un tiempo me causó tristura" (Orígenes. . ., t. 2, p. 440)

${ }^{48} \mathrm{He}$ aquí una repitiente antología:

-Olivos: "está llorando vn Pastor/ a la sombra de vn oliuo:/ y tiene en el verde tronco/ vn coraçon esculpido/ de vna flecha atrauessada [sic]/y estas palabras a escrito:/ quexaraste de ti mismo/ pues quies a quien no te quiso"' (Fuentes..., t. 3, f. 66), "en cortezas de olivos entallando/ sus versos, cual si Apolo los dijera" (Soneto de Baltasar de Escobar en alabanza de Herrera, en Rodríguez Marín, op.cit., p. 142, nota 4; con alguna diferencia, en BóHL DE FABER, Floresta, t. 2, p. 302, núm. 556), "I en la selva de Alcides' el hermoso/ coro, entalla y escriue en la corteza/ del' abundosa oliva, por grandeza/ tu nombre ilustre i verso numeroso" (Soneto de Francisco Pacheco a Juan de la Cueva, en Margarita Peña Muñoz, "Juan de la Cueva, poeta del cancionero Flores de baria poesia', $C H(7)$, p. 801).

-Fresno: "Fresnos, en cuya cortezal escribí tantos requiebros"' (Anfriso, desesperado, en La Arcadia de LOPE, BAE, t. 38, p. 109; cf. TIRSo, La fingida 'Arcadia, $N B A E$, t. 4, p. 448: "Fresnos en cuyas cortezas/. . escribió el alma verdades"), "En la corteza de un fresno..." (Rodríguez Lobo, en Gallar. DO, op. cit., t. 4, col. 233), "En aquel fresno levantado escribí las primeras señas y muestras de mis primeros favores"' (Rojas, Viaje entretenido, en Origenes..., t. 4, p. 524).

-Aliso: "Acuérdome bien (si penas / me dexan bien acordar)/ qen vn trōco de vn aliso.../ escriuió tu mano vn dial Yo te doy mi libertad..." (Romancero General de 1600, ed. cit., f. 34; en Fuentes. ., t. 2, f. 101, la errata “eliso"'), “. . .lagrimoso informante de su pena/ en las cortezas que el aliso viste" (GónGORA, ed. cit., t. 2, p. 356).

- Moral: "estava un moral lleno de su cuerdo fruto, con una corona pendiente de sus ramas, y una letra que dezía: Para ti. Y en las cortezas: "A quien cual yo con paciencia/ y esperanças se sazona/ la possessión le corona"" (TIR- 
so, Cigarrales, ed. Said Armesto, p. 140).

-Laurel: "Mas en el mismo laurel/ se porná con un cuchillo" una falsa escritura funeraria (JUAN DEL EnCINA, Égloga de Plácida y Victoriano, ed. E. Giménez Caballero, Ebro, Zaragoza, vv. 1739-1740), "Este lauro que tiene en su corteza/ verde escrita la honra de mi pena" (HERRERA, "Soneto XXXVIII" en $B A E$, t. 32, p. 262), "La lira de Garcilaso/ junto a su cristal luziente/ halló de un laurel pendiente/ Tirso, y esta letra escrita:/ «Fénix, en ti resucita,/ canta, y corona tu frenten"' (LOPE, en Tirso de MOlina, Las Cigarrales de Toledo, Renacimiento, Madrid, p. 11), "Laurel, honor del valle, ydolo mío,/ que el nombre escrito tienes de mi ingrata. . " (Soneto 124: "A un laurel donde estaba escrito el nombre de una dama", en $R H i, 18$ (1908), p. 551). El laurel da pie a la enigmática copla popular recogida por Schindler: "La firmeza no está en los hombres,/ no está en los hombres ni en las mujeres,/ que está en el tronco de los laureles", núm. 201; cf. núm. 518: “Arboluco, te sequestes/teniendo la fuente al pie/ en el tronco la firmeza/ y en la ramuca el querer"'.

-Roble: "Los pastores escriuian/ en los Robles su [de Darinel] historia" (Libro segundo de las obras en coplas de Núnez de Reinoso, Giolito, Vinegia, 1552, p. 84), "En el robre y su corteza/ con el agudo cuchillo/ pinta el dolor no cencillo [sic]/ que padece de crueza" (JuAN DE LiNares [sic], Flor de enamorados, en Cejador, La verdadera. . ., t. 6, p. 199, núm. 2577), "Alli, por montes y prados,/ podrás leer todas horas,/ en mil robles señalados,/ los nombres más celebrados/ de las ninfas y pastoras. Mas seráte cosa triste/ ver tu nombre allí pintado... " (Diana de Gil Polo, ed. López Estrada, p. 132; en BöHL DE FABER, op. cit., t. 2, núm. 514), "Canción, en la corteza deste roble,/ solo y desamparado/ de verdes hojas, verde vid y verde/ yedra, quedad..." (FRANCISCO DE LA TORRE, "Canción I"', en el Tesoro de Quintana, p. 62, y en p. 28 de la ed. de Espasa-Calpe), "Esta selva, a cuyos robres/ por muchos verdes colla$\mathrm{dos} /$ falta número a sus pies/ y falta sitio a sus brazos,/árbol no alimenta adonde/ no haya puesto mi cuidado,/ escrito el nombre de Lisis/ desde la planta al penacho" (DOn García de PORRAS, en el Cancionero de 1628, p. 480). López DE Zárate injerta el motivo en el idilio de Jacob y Raquel: "Si en voz dulçe y tiernos versos,/ tal vez, escuchó sus gracias,/ o las vio en robles, escritas,/ que aun dichas de vn roble agradan" (ed. cit., p. 367, "Romance XV").

-Olmo: "En un olmo Vandalio escribió un día..." (GutierRe DE CetiNA, en GallaRDO, op. cit., t. 2, col. 413), "Las [penas] que otro tiempo pasaba/ mal escritas en los olmos,/ las leyeron todo el año/ cuantos bajaban al soto" (EsQuilache, “Romance X", gentileza de María Rosa Lida), "Infórmenos lo liso de aquel tronco;/ hondo supe escribillo;/ aquí está mi cuchillo,/ que fue siempre á los olmos importuno,/ sin perdonar de aquestos campos uno", (Pedro Sotode Rojas, "Égloga" en $B A E$, t. 42, p. 527). Los ejemplos de LoPE abundan: "Dijo, y en un olmo verde/ estas palabras escribe:/ "Cuanto es Amarilis bella/ es Fabio en amalla firme"" (Poesias líricas, ed. J. F. Montesinos, Espasa-Calpe, Madrid, t. 2, p. 67), "en la corteza de los olmos lisa/ (ingenio singular) compuso Albano/ floridos epigramas... ' (Parnaso de Sancha, t. 3, p. 53), "Tú, claro río.../ desde los olmos de tus verdes vegas/ lleva su nombre al mar" ("En la muerte de Baltasar Elisio de Medinilla" en $B A E$, t. 38, p. 366), "en un olmo. . . Alfesibeo, un ingenioso vaquero, talló con un pequeño cuchillo esta epigrama..." (La Arcadia, ibid., p. 104), "Quede en 
los olmos desta margen verde,/ para que siempre la memoria acuerde/ desta historia el ejemplo..." (La selva sin amor, f. $115 \mathrm{v}^{\circ}$ del Laurel de Apolo, con otras rimas. . . En Madrid, por luan Gonçalez, 1630; también en BAE, t. 38, p. 306). Si el olmo atrae hasta a quien no sabe qué nombre escribir ("Como yo no sé escribir/ vuestro nombre, tengo llenos/ los blancos olmos del Tajo/ por cifra del nombre vuestro,/ de Flores mal retratadas,/ assí la vida entretengo", Juan de Matos Fragoso, Lorenzo me llamo y Carbonero de Toledo, suelta sin año) goza el triste privilegio de servir para epitafios más que otro árbol: así sucede con las plantas que rodean el sepulcro de Sasio, en El pastor de Fílida, y notablemente con el olmo que lo recubre y recibe la más memorable octava funeraria (única citada en este pasaje de la novela): "y en muchas plantas que [la sepultura] alrededor tenía se escribieron diversos epitafios en sus loores; mas entre todos el famoso Tirsi, cuyas Rimas tantas veces Sasio solía cantar, en el tronco de un olmo, que con sus ramas cubría el ancho sepulcro, escribió estos versos de su mano. .." (Orígenes, t. 2, p. 575); Pedro de Medina Medinilla forja el autoepitafio ulmáceo de su Belardo: "mas ya no estampo/ mis dichas en los olmos, cual solía... / quedando en este tronco duro y pardo/ escrito con la punta de este dardo,/ porque haya troncos de mis males llenos:/ "Aquí acabó Belardo/ que más amó, y gozó su gloria menos"" " "Égloga en la muerte de doña Isabel de Urbina, muger de Lope de Vega" en el Parnaso de Sancha, t. 7, p. 144; Martínez de la Rosa cita parcialmente este texto en la nota 3 del canto IV de su Poética); y otro desdichado pastor lega sus pocos bienes al que encuentre sus restos y les dé la piadosa sepultura que merecen: "y en remuneración de tan buen celo/ haya este mi rabel y vestidura,/ con tal que en aquel olmo más cercano/ escriba este epitaphio de su mano", con la octava que se dedica ("Octavas antiguas, del Brocense", pp. 810-811 del Catalogas librorum Doctoris D. Joach. Gomez de la Cortina, t. 4, Matriti, apud Eusebium Aguado, 1859). A veces el árbol funerario no se determina: "un solo bien por tanto mal te pido,/ que moriré contento, concedido./ El cual es que en un tronco limpio y puro/ del árbol más crecido, con tu mano/ escribas porque dure en lo futuro/ $\mathrm{mi}$ gran amor y tu trofeo inhumano:/ "Llorad, llorad, pastores, el fin duro/ de vuestro amigo en la montaña y llano./ Meliseo murió: llorad, pastores:/ yo Filis le maté con disfavores"' (LOMAS CaNTORAL, en GaLlardo, op. cit., t. 3, col. 410).

- Álamo: "apartada algún tanto, en la corteza/ de un álamo unas letras escrebía" (GARCILASO, "Égloga III", ya citada; sigue una octava, "como epitafio de la ninfa bella"); " Herbanio, pastor señalado en la Andalucía, . . . en la corteza de un álamo, sirviéndole de pluma un punzón, delante de mí escribió este soneto..." que se transcribe (Diana de GaSPar Grl Polo, en Orígenes. . ., t. 2, p. 413); "'llegando a la cabaña de Filena, en la corteza de un álamo que junto a ella estaba, dexó escrita esta piadosa despedida..." (L. GÁLvez DE Montalvo, El pastor de Fílida, ibid., p. 558); "No hay en todo el valle/ álamo acopado/ donde el nombre suyo/ no tenga estampado" (JERÓNIMO DE ARBOLANCHE, en Gallardo, op. cit., t. 1, 262, 231; "copado" en CEJADOR, op. cit., t. 7, p. 112, núm. 2779); "y del crespin en el corriente lecho/ los álamos yo escriba que lo honraron/ del nombre que escribió Amor en mi pecho" (GuzMÁN MeXía, Vida y tiempo de Maricastaña, en Gallardo, op. cit., t. 4, col. 1532); "cubrió las almas tan alegre exceso,/ que no hay álamo blanco en nuestro río/ que en su corteza no le tenga impreso" (LOPE, Amarílida, en BAE, t. 38, 
p. 309); " "no quede álamo blanco, en cuyo tronco/ no escriban los pastores Sayabedra/ a pesar de los círculos de hiedra"' (LOPE, Laurel..., VI, 119, sobre Diego de Saavedra Fajardo); "que tus gloriosos excessos,/ si de mi Musa los fias/ los veneraran los dias/ en los alamos impressos" (GónGORA, "Honra de la reina Da. Margarita", ed. cit., t. 2, p. 7): y lo mismo en los cantares ("Escribió por la corteza/ de los alamos su fe" - "De los álamos vengo, madre", núm. 135 del Romancero de Barcelona, RHi, 39, 1917, p. 184-; "Si alguna vez divertida/ con vosotras se aconseja/ mostralde letras y amores/ en vuestras toscas cortezas", "Alamos del soto, adiós"', con música de Juan Blas, en el Cancionero de la Sablonara, t. 6, 291) como en la prosa, jocosa o doctrinal (Saavedra Fajardo: véase el final de la nota 121; "Y porque con el tiempo y los varios sucesos que podían venir por él no le faltase la memoria, con el mismo cuchillo [de monte con que había hecho el hoyo para guardar su dinero] escribió en el álamo que estaba más junto, de letras mayores, como las que usan en los rótulos de las cátedras, sola esta palabra: 'Aqui'"; y completa la leyenda, en cuatro octosílabos, el que lo vio hacer y lo despoja, que "con un cuchillo que traía en un estuche escribió estas palabras en el mismo álamo...", BALTASAR Mateo VelázQuez, El filósofo del aldea, en el t. 4 de la Colección selecta de antiguas novelas españolas de COTARELO Y MORI, PP. 251 y 252).

-Encina: "Del claro Betis lo digan/ las encinas que alimenta,/ que bien para elogios tuyos/ tendrán voces sus cortezas" (TRILLO y FigueroA, "Romance IX, satírico" en $B A E$, t. 42, p. 62); "y en la verde corteza/ de tu frondosa encina mi cuidado/ extendiendo, conmigo lo leyeras" (HERRERA, "Égloga II, venatoria" en $B A E$, t. 32, p. 341; vv. 2606-2608 de la ed. de García de Diego, con grafía más genuina: "i", "enzina", "'estendiendo, conmigo"'); Juan de la Cueva parecería extenderse de la encina a toda suerte de vegetal labrable: "En dura encina al natural sacada/ de sutil mano tengo tu figura.../ No hay planta en todo aquesto que no vea/ ¡ay ninfa ingrata! tu belleza puesta,/ que en esta obra solamente emplea/ el alma la memoria en ti traspuesta..." ("Égloga", en el Parnaso de Sancha, t. 4, pp. 363-364).

-Peno: "Aquí está un pino, donde yo he leído/ versos escritos de su propia mano" (HuRTADO DE MENDOZA, "Égloga III", p. 74); "en la corteza dura de este pino/ poner este epitafio determino" (Francisco de Figueroa, EL Divino, "Estancias" en $B A E$, t. 42, p. 509); " Quiero de Albania al resplandor divino/ consagrar de improviso un epigrama/ con aqueste cuchillo en este pinr" (Lope, La 'Arcadia, en BAE, t. 38, p. 98).

- Sauce: "Que de vezes por los sauzes/ en sus delgadas cortezas,/ escriuio como furioso/ mil lastimosas endechas" (Romancero General de 1600, ed. cit., f. $46 \mathrm{v}^{\circ}$ : en Fuentes..., t. 3, f. 8, "escriui", más la errata "saluces"); "Al pie de un hermoso sauce/ está un pastor desmayado" que deja, según parece ser costumbre, sus bienes al que lo sepulte, "con tal que en aqueste sauce/ deje escrito este epitafio" - por una vez modesto, de sólo seis versos (Romancero de LUCAS RODRíGUEZ, reimpreso en la Colección de libros raros o curiosos, t. 10, pp. 345 y 346); " La vi escribir con mentirosa mano/ de aquellos verdes sauces las cortezas", Esquilache, "Égloga III", ya citada, en el Parnaso de Sancha, t. 8, p. 250).

- Haya: "y aquestas verdes hayas y sombrías/ el mismo nombre en sus cortezas vieron" (Esquilache, id., p. 244); "Esto Zelindo escriuio/ en el tronco de vna haya" (Romancero General de 1600, ed. cit., f. 98 [90]; en Fuentes. . ., 
t. 4, f. 35); " Los versos que el otro día en las hayas de aquel bosque escriuiste" (Cervantes, La Galatea, ed. Schevill-Bonilla, t. 1, p. 154; cf. las "casi dos docenas de altas hayas" que llevan "grabado y escrito el nombre de Marcela", Quijote, I, xii).

-Palma: "Vi vnas letras que dezian,/ en el tronco de la palma..." (siguen seis versos de este repetido romance: Romancerillos de la Bibliothèque Ambrosienne, en $R H i, 45$ (1919); Romancerillos de la Bibliothèque de Pise, id., 65 (1925), p. 189 (sin la coma); Fuentes. .., t. 4, f. 26, y t. 5, f. 40 v $^{\circ}$; Romancero General de 1600 , ed. cit., f. 13 , etc.); "Hallaron también en las corteças de su tronco [el de "una empinada palma"], escrito este Epigrama, si no le queréys llamar Soneto: ..."' (TIRso, Cigarrales, ed. cit., p. 286).

-Ciprés: "En el tronco de un cipres...,/ estas palabras estampa" (Romancero general de 1600, ed. cit., f. 13; Fuentes..., t. 2, f. 39: En un tronco de un cypres...; de Lope, según González Palencia); "Aquesto [cuatro versos sobre volver atrás el río y nevar en verano como imposibles menos imposibles que variar los amores] vio Fileno en vn hojoso/ cipres. . ." "Somos 150" (en $R H i, 18,1908)$; "En el tronco de un ciprés grande estava gravada una Cruz y á su pie escrito: "Aquí mató la ausencia presumida una voluntad amante. Rueguen á Dios por ella»" (TIRSo, Cigarrales, ed. cit., pp. 153-154).

- Castaño: “y arrimándose al tronco del espinoso árbol [!] . . . le enseñó unos versos [un soneto funeral] que le refirió haberlos él escrito, cortando con la punta del cuchillo de su estuche la dura corteza que le cobija" (ANDRÉs SANZ DEL CASTILLO, La mojiganga del gusto, en la Colección de antiguas novelas españolas, t. 8, p. 83).

-Revoltillo: "Cuia graue passion i pena doble/ ha vencido el desden i la dureza/ del laurel casto i del robusto roble,/ i dellos cada qual por su corteça/ lagrimas muchas vezes ha sudado/ de Amor el Lauro, el Robre de terneza" (GÓNGORA, ed. cit., t. 3, pp. 54-55: ¿simple alegoría?: cf. "No ai verde frexno sin letra,/ ni blanco chopo sin mote" del romance "En un pastoral albergue", $i d_{\text {. }}$ t. 1, p. 228, núm. 131); "Ni pienso que algún olmo o salce hubiese/ do escrita de mi mano por tu gloria/ parte de tu valor no se leyese" (HERnANDo DE ACUÑa, "Elegía"' en el Parnaso de Sancha, t. 7, p. 83); "Seluas y bosques de amor,/ en cuyos olmos y fresnos/ aun viuen dulces memorias/ del pastor antiguo vuestro..." (Primavera y flor, f. 82; Gallardo, op. cit., t. 1, pp. 297, 271 , da sólo los dos primeros versos: es el núm. 106, p. 150, de las poesías líricas de Lope editadas por Montesinos, quien en p. 259 da la noticia: "Incluido por Lope en su novela Las Fortunas de Diana [La Filomena, 1621]. El romance figura también en el manuscrito 3.700, como de Lope, sin divergencias de consideración, y anónimo en el Cancionero antequerano. Fue, sin duda, sobremanera popular; Gracián, Agudeza, ed. cit., p. 36, cita ocho de sus versos, y lo imita burlescamente Quevedo en otro del mismo comienzo, ed. Astrana, p. 275; " "escribiendo por estos olmos, por estas hayas, por estos pinos, tu crueldad y mi pena, tu beldad y mi firmeza..." (Gálvez de Montalvo, El pastor de Filida, en Orígenes..., t. 2, p. 566); “Ginesa: Pues, hijo Quiral, sábete que ni voy a la fuente por agua, ni a visitar las colmenas, ni a las labranzas de mi amo Socrato, que las tiernas plantas no manifiesten tu nombre. Quiral: $\mathrm{Me}-$ nos entiendo eso. Ginesa: Pues yo sí: que andando muchas veces con Camila por aquestas frescas fontanas, le vide descuidadamente de un hermoso estuche sacar un pequeño cuchillo, y en las tiernas hayas, pinos y sauces, y en otros 
montesinos árboles, debujar el nombre de Quiral; así que pocas son las plantas que no manifiesten tu nombre"' (LOPE DE RUEDA, Camila, pp. 42-43 de la ed. de la Real Academia); "y ya que como Pastor Arcade esculpistes en otros tiempos loores y alabanzas a vuestro Dios Pan, tan olvidado de vos, tendreis en este çarçal, no solo Siruelos, finos robles, Encinas, Mestos, Nogales, Pinos, Mançanos y Perales en quienes esculpir lo que mas quisieredes"' (UotigaN ILASCON [Agustín Nicolás] a don Carlos Andrés Sinibaldi, dedicatoria de su Bosque de las horas perdidas, 1694, p. 4).

${ }^{49}$ En el Tesoro de Covarrubias, s.v. "deshazer. Borrar lo hecho". La difusión del poema, evidentemente citado de coro, explica sus no pocas variantes: el "Soneto 10 ", $R H i, 18$ (1908), p. 493, reza "de aquella su pastora, a quien habia/ en mil cortezas de arboles cavado"; y en las poesías de su presunto autor, Trillo y Figueroa ("Soneto III", en $B A E$, t. 42, p. 45) se lee "Daliso con el cuento de un cayado/ el nombre deshaciendo estaba un día/ de su Fílida ingrata, que él había/ de un roble en la corteza ya grabado"

${ }^{50}$ Esquilache, en el Parnaso de Sancha, t. 4, p. 228.

${ }^{51}$ Montalvo, El pastor de Fílida, ed. cit., p. 489.

${ }^{52}$ Ed. cit., f. 92; ya en Fuentes. ., t. 4, f. 19, y t. 6, f. $200 \mathrm{v}^{\circ}$.

${ }^{53}$ Tratando del Siglo de Oro de Balbuena, MIA GeRhard, Essai d'analyse littéraire de la pastorale dans les littératures italienne, espagnole et française, Van Gorcum, Assen, s.a., p. 195, apunta: "Les traits pastoraux qui suivent sont traditionnels: l'air affligé du berger, les vers gravés dans l'écorce d'un arbre et qu'il efface..." y cita a su Beroaldo, que "con una podadera començo a borrar ciertos versos, que pocas [sic] dias antes en la corteza de un arbol avia escrito". Suprimir un nombre es acto grave, como reverso del entusiasmo que impulsaba a Anna de Noailles niña (¿y después, también?) a extenderlo por doquiera para afirmar y fortificar su "yo". En lo antiguo era castigo cruel; AxEL MUNTHE recuerda a quienes así procedieron contra el faraón herético Akenatón: "borraron su nombre aborrecido de las hojas de oro que lo cubrían, condenando a su alma a vagar sin nombre, entre las tinieblas, por una eternidad' (El libro de San Michele, Edición Letras, Buenos Aires, p. 429). El mismo valor deploratorio da Virgilio a la muerte de Príamo, cuyos "'restos yacen ahora insepultos en las playas de Ilión; de aquel gran rey sólo quedan una cabeza separada de los hombros y un cuerpo sin nombre" (La Eneida, trad. Eugenio de Ochoa, Losada, Buenos Aires, 1947, p. 54; el v. 558 del libro II precisa: "avulsumque umeris caput et sine nomine corpus"). Inspirada sin duda en el epigrama XXIII del Pseudo-Teócrito ("La inscripción te dirá cuál es este monumento, y quién reposa bajo él: Yo soy la tumba de la llamada Glaukes", p. 131 de la ed. Legrand), "qu'elle seule me pleure. Je ne dis pas son nom", blasona la estela de "Le tombeau sans nom" en las Chansons de Bilitis, y ésta misma concluye: 'Longtemps nous sommes restées debout, et nous n'avons pas versé la libation. Car comment appeler une âme inconnue d'entre les foules de l'Hadès?" (p. 70, núm. 41). El poema de Pierre Louÿs inspiró el segundo de los Six épigraphes antiques de Claude Debussy, "Pour un tombeau sans nom", y esta composición suministró el título definitivo de la novela de Onetti Para una tumba sin nombre: la reedición de Barcelona (Pocket-Edhasa, 1980) lleva un "Estudio preliminar" de Josefina Ludmer que dice todo lo que puede decirse de ella y más, salvo este detalle, confirmado por el título inicial (Una tumba sin nombre), completado por el autor para adicionarlo a las constantes 
alusiones musicales de sus títulos: "Historia del caballero de la rosa" (aproximación a Richard Strauss), "La novia vendida"' (Smetana), "Los adioses" (Beethoven), "La vida breve" (Falla; en 1932 Roberto Arlt había publicado El amor brujo), "La muerte y la niña" (Schubert), no sin relación - bien que algo menos socarronamente- con los títulos similares de André Gide: La symphonie pastorale, La marche turque... El poderío del nombre, en la recordación funeraria, actúa ininterrumpidamente: visitando el cementerio de su pueblo natal, Marcel AR LAND diferencia "ces tombes: celles des miens, des parents, des alliés, des compagnons d'école (Gabriel, Louis, André, Léon, Alfred, Henri. ..., m'entendez-vous?; [de] celles de gens qui sont venus après eux, mais que je n'ai pas connus; çà et là, quelques tombes du vieux temps, privées de noms et presque de forme" (Lumière du soir, NRF-Gallimard, Paris, 1983, pp. 25 y 69); " "je gagnais une autre tombe, une autre, celle de Gustave, mon parrain, celle d'une cousine, celles d'un docteur, d'un prêtre, d'un enfant mort-né, celles des vieux d'autrefois, celles, rongées d'usure et d'oubli, dont j'essayais d'imaginer les hôtes, pour qu'ils puissent revivre un instant, s'accouder au mur d'enceinte et revoir le beau pays qui leur fut accordé..."

${ }^{54}$ Origenes..., t. 2, p. 428.

${ }^{55} \mathrm{H}$. Golezer, en el prólogo de su ed. de las Bucólicas, señala que "Au vers 15 de la $5 \mathrm{e}$. Bucolique, Mopsus nous dit qu'il a gravé ses vers sur le tronc d'un arbre, et, dans un de ses poèmes (I, 11), Calpurnius nous parle du même procédé. Sans doute, on n'écrivait ainsi que quelques vers et non des poèmes entiers; mais ces vers étaient parmi ceux qui avaient acquis au poète sa réputation, et, en rappelant cette célébrité, Gallus pouvait dire avec confiance qu'elle grandirait en même temps que les arbres à qui il confiait le soin de la perpétuer". Sobre este punto, véase más abajo la descendencia de la décima égloga virgiliana; cf. VIRGILE, Bucoliques, Les Belles Lettres, Paris, 1933.

${ }^{56}$ Fuentes, t. 4, f. 35.

57 "Cuando algún río do nació volviere,/ cosa que nunca fue vista ni oída". Corrientes son los ríos que mansamente van siguiendo su natural camino; y tan corrientes son, que como tales los vaticinan las Profecias de Pero Grullo de Gabriel de Peralta: "Dice también que vendrán/ tiempos sin haber desvíos/ que las aguas de los ríos/ hacia abajo correrán/ con calores y con fríos" (Gallardo, op. cit., t. 3, col. 1146, copla 4; cf. CeJADOR, La verdadera..., t. 2, pp. 14-15, núm. 1129). Los ríos de la poesía española participan de esa cualidad: "No se qual es el necio y majadero,/ que dexa su reposo y su contento,/ por pretender boluer atras el Duero"' (SÁNCHEZ DE LiMA, ejemplo de tercetos en su Arte poética, ed. Balbín Lucas, p. 61); "Nunca las ondas/ tornan del Tajo a su primera fuente..." (Quintana, "A la invención de la imprenta" en la ed. de Espasa Calpe, Madrid, p. 165, y vv. 28-29 de p. 168). $Y$ lo mismo ocurre en los ríos de habla inglesa, aunque se expresen en traducciones: "Elle n'aurait pas été plus étonnée de voir le soleil rétrograder vers l'Est ou la Tamise remonter subitement vers sa source"' (CHESTERTON, Le retour de Don Quichotte, Bloud \& Gay, Paris, 1928, p. 123); "Je ne puis faire revenir le ruisseau en arrière,/ car moi aussi le courant m'emporte"' (poema de Brian, en Patricia Highsmith, Eaux profondes, Calmann-Lévy, Paris, 1980, p. 302). La fatalidad expresada en el libro segundo de los Reyes (XIV, 14: "Omnes morimur, et quasi aquae dilabimur in terram, quae non revertuntur"), resuena en las letras españolas: "que ni vuelve atrás el río,/ ni retroceden los 
cielos" (Trrso, La fingida Arcadia, ed. cit., t. 2, p. 1398), "que ni al río has de pedir/ que retroceda su curso"' (Tirso, Ventura te dé..., id., t. 1, p. 1544), "porque yo solo confío/ que atras no boluerá un río" (MALUENDA, ed. Juliá Martínez, t. 3, p. 233). Su trasposición al ámbito de la humana conducta dota a la imagen de una posible flexibilidad; el hombre puede (o no) asemejarse a la corriente: "Pero soy tornado río,/ que no me puedo tornar/ aunque quiero" (Gómez ManRiQue, Cancionero castellano del siglo $X V$, núm. 332; en la Métrica de BAEHR, p. 326); “ “hasta cuándo imitarás/ en no volver paso atrás/ al tiempo veloz y al río?" (TIrso, El honroso atrevimiento, id., t. 2, p. 1157). Flexibilidad desmentida en el caso de la palabra de los grandes, desde el Sujeto de El condenado por desconfiado ("Tu palabra, es caso cierto/ que atrás no puede volver", ed. cit., t. 2, p. 470) hasta sus ministros terrenales: lo dice al Rey la Reyna de No hay dicha. . . de Rojas Zorrilla, hacia el final del acto II: “"porque las palabras nuestras/ son ríos, que atrás no bueluen,/ si no es con infamia y mengua..."; y la formulilla de los cuentos infantiles ("Palabra de rey no puede faltar") retorna engañosamente en La desheredada de GaLDós: "-Un Miquis no vuelve atrás; un re non mente: la palabra de un Miquis es sagrada" (p. 76 de la reed. de Alianza, Madrid, 1980); pero Miquis no se casará con Isidora. La humana flaqueza opta, generalmente, por la forma negativa de la imagen: "No soy rio, para no boluer atras"' (Hernán Núñez, 85); la Fraseologia de Cejador, t. 4, pp. 466-467, recoge las dos formulaciones de Correas (“No soy río..." y “ ¿Soy río para no volver atrás?”) con la variante de Galindo: "No soy río para no poder volver atrás" y el refranero de la Revista de Archivos, Bibliotecas y Museos (núm. 297, p. 442) da la versión "No so rio que que no me buelua"; Caballero Rubio (en la $2^{\circ}$ reed. de El Ateneo, Buenos Aires, 1947, p. 360) amplía y explica: "Como no soy río, atrás me vuelvo. Expresión fam. con que tratamos de disculpar un cambio de parecer sobre alguna cosa"; en la cuarta colección de refranes de Rodríguez Marín hay variantes en las pp. 107, 222 y 271 . El uso literario de la frase es frecuente: "que después, pues no soy río,/ bien puedo volverme atrás" (Tirso, Amar por señas, id., t. 1, p. 1697); "No ande más, gran señor,/ deténgase, que no es río", (Tirso, Adversa fortuna ..., id., t. 1, p. 1902); "No eres río, vuelve atrás" (LoPE, El valiente Céspedes, en Obras escogidas, t. 2, p. 1346); un ejemplo americano de fray Adriano de Alecio en la Antología poética peruana de MANUEL BeLTROY, p. 28: ". . . si se casa con Pepe, es porque la plabra es palabra; pero, lo que yo digo: como la mujer es río, puede volverse atrás.. iy qué sé yo!" (Polo y Peyrotón, op. cit., p. 388). Varias causas, empero, pueden trastornar sus cursos; las hay materiales y cotidianas: Lope señala un par de veces una: "esse río junto al mar,/ que vuelve atrás, aunọue es río"' (Para querer..., vv. 136-137; su editor, KOHLER, explica: "oui reflue") "y no digo que este río/ se vuelva primero atrás,/ pues el mar, que puede más,/ le vuelve atrás con tal brío" (El arenal de Sevilla, en Obras escogidas, t. 1, p. 1394): Hay la magia, tomada ovidianamente en serio (la Prosa IX de La Arcadia de SANnaza. RO ed. Scherillo; "y si atrás hago á Flagetón volverse", JUAN DE LA CuEVA, Farmaceutria, en CatLaRdo, op. cit., t. 2, col. 721: en la siguiente sale el enfrenar el cursa de los rías; y también la "Elegía" de Viltegas en el Parnaso de Sancha, t. 7, p. 369), o puesta en solfa ("Volver haee a sus fuentes las corrientes", Hurtado oe Mendoza, "Sátira a una alcahueta", p. 442; y en el mismo espíritu, "era tal su artifício/ que hiciera cuajar la mar/ y volver atrás los 
ríos", LOPE, El llegar en ocasión, citado por MAXIME CheVALIER en sus Cuentos españoles..., p. 230). La repetición y la luz del entendimiento (con las del siglo) arrinconan los encantamientos ovidianos: "Je suis lasse du soleil et de la lune dont une vieille dispose à son gré, des montagnes qui dansent, des fleuves qui ressuscitent; mais surtout, quand ces fadaises sont écrites d'un style ampoulé et inintelligible, cela me dégoûte horriblement": así opina la bella Amaside en el onceno capítulo de Le taureau blanc (Romans et contes de Voltaire), Firmin Didot, Paris, 1844, p. 526; lo cita también JacQues Bainville, Le jardin des lettres, Éds. du Capitole, Paris, 1929, t. 1, p. 95). Fuerzas espirituales y materiales logran también el portento: "rogar te vimos.../ con tal piedad, que atrás volver un río/ pudieras" (JUAN RUFO, "Soneto", Las seiscientas..., ed. A. Blecua, p. 343); en la de Aljubarrota, "Guadiana/ atrás tornou as ondas de medroso" (CAMŌES, Lusiadas, IV, 28, vv. 3-4); "La fábrica postró, y al gran ruïdo/ volvió del Tigris la corriente brava/ atrás", MiRA DE AMESCUA, Teatro, Espasa-Calpe, Madrid, p. 143). A casos prodigiosos puede atribuirse el turbar la costumbre natural de los ríos: "Yo crech qu'el Tibre llauors/ fugirà del mar salat/ quant la sort del meu peccat/ me traurà d'estos amors" (ToRres Naharro, Comedia Seraphina, ed. Gillet, t. 2, p. 28); en el esplendor de Las fiestas de Lerma se vio "a su origen boluiendo la corriente" (LÓPEZ DE ZÁRATE, ed. Simón Díaz, t. 1, p. 124), con imagen que cabe retraer hasta Horacio ("Relabi. Reculer en arrière, remonter vers sa source [en parlant d'une rivière]", Q. Horatii Flacci opera ..., curante Jos. Valart Parisiis, typis Michaelis Lambert, 1770, p. 494). Y no debe olvidarse el poder de la música: "y quando acaso tañía/ ó tocaba su viguela, / á los ríos detenía. .." (SEBASTIÁN DE HOROZco, "La fábula de Orpheo y Euridice su mujer", en su Cancionero, p. 254 ss.: la influencia del episodio inicial del libro X de las Metamorfosis sobre Juan de Mena la señala su glosador sobre las coplas 52, 63 y 104 del Laberinto; y a pesar de saber ligeramente a errata, merece recordarse el "Orfeo con la pompa paró el río" de Villegas ("Epístola al Rector de Villahermosa contra los que afectan el escribir obscuro", en el Parnaso de Sancha, t. 9, p. 7); y también el Parnaso (t. 7, p. 76) recoge el modesto deseo de Hernando de Acuña: "Si Apolo tanta gracia/ en mi rústica cítara pusiere/ como en la del de Tracia/ ... y refrenase/ el curso de los ríos... ": puede decírselo sin ironía "modesto", cuando otros (¿mejores?) plectros se lo conceden redondamente: en el mismo volumen, p. 15, Herrera proclama que "el curso refrenando/ el sacro Hesperio río,/ mil veces se detubo al canto mío"; y también Camōes se jacta: "Frauta mia que tangendo/ os montes fazieis vir/ para onde estaveis, correndo,/ e as aguas que iam decendo/ tornavam logo a subir"'). Con mejor urbanía, JUAN DE LA CUEVA concede este poder al estro ajeno: "del ecelso Mal Lara oíd la lira. . / La que hace bajar al sacro Apolo,/ al Po glorioso el curso atrás retira" y es para él Alcázar "por quien levanta la hermosa frente/ el gran Betis, y á oir el noble acento/ atrás vuelve el furor de su corriente", (en Gallardo, op.cit., t. 2, cois. 677 y 724). No menos poderosa que el Orfeo ovidiano es la singular Gelasia del romancero nuevo, que cuando se acompaña con su arpa "Tan suavemente canta/ que tras sus acentos lleua/ a quien la oye los sentidos,/ y el alma a quien la dessea./ Detiene su curso el río...' (Fuentes, t. 4, f. $41 \mathrm{v}^{\circ}$; en t. $6,209 \mathrm{v}^{\circ}$, con alguna variante). En este preciso terreno pastoril, la influencia de Virgilio es preponderante: al canto del Alfeo y el Damón de su égloga octava, "los ríos sosegaron su corriente" (traducción de Fray Luis, 
en el Parnaso de Sancha, t. 1, p. 209); iguales efectos tiene el canto amebeo de Montano y Lucindo en la "Égloga" de LOPE DE VEGA (id., t. 8, p, 129); y es quizás en FRANCISCO DE LA TORRE en quien más aflora el eco virgiliano: "Títiro mío, la gloriosa llama/ cantando, vuestro Tajo y mi Xarama/ paráis al son de vuestra hermosa Lyra", " "las sonorosas aguas deteniendo... / al son dulce acordado/ de una sonora lira", "los amenos ríos,/ alguna vez tenidos y amansados/ al son de mis acentos lastimados" (pp. 3, 133 y 151 de la ed. de Zamora Vicente). La idea de comparar la fidelidad amorosa con la perpetuidad irreversible de un río - ya para alabar la propia firmeza, ya para enrostrarlo a quien se jactó falsamente de ella usando esa imagen- es tan genérica (si así puede decirse) que encuentra su lugar indisputado en los tratados y discursos de retórica; Du MARSAIS, en el suyo (Des Tropes ou des différents sens dans lesquels on peut prendre le même mot dans une même langue. ., $3^{\mathrm{e}}$ éd., à Paris, chez M. Nyon, 1787 , pp. 121-122) cita la Ifis de Quinault ( $3^{a}$ escena del $I^{\circ}$ acto: "Vous juriez autrefois que cette onde rebèle/ se feroit vers sa source une route nouvèle,/ plutôt qu'on ne verroit votre coeur dégagé:/ voyez couler ces flots dans cette vaste plaine;/ c'est le même penchant qui toujors les entraîne;/ leur cours ne change point, \& vous avez changé... '” cf. el conocidísimo Plaisir d'amour de Martini y las "bergerettes"' adyacentes); y Hermosilla (Arte de hablar, t. 1, p. 141) elige como ejemplo de imposible o adynaton versos de la primera escena del acto segundo del Aminta de Tasso y su traslación por Jáuregui: "torneranno i fiumi/ alie lor fonti", y "hacia sus fuentes volverán los ríos". Ya bajo el pasaje análogo de Sannazaro (pp. 51-52 de su ed.), Scherillo apunta los versos 18 y ss. de la quinta égloga virgiliana (ligeramente diferentes), los vv. 9-10 y 31-32 de los Amores de Ovidio (I, xv), y la sestina I, 3 de Petrarca; cabría añadir, con los vv. 29-30 de la heroida quinta de Ovidio (volverá atrás el Janto si Paris abandona a Enone), el pasaje de Propercio parafraseado por Julien Benda ("ma fameuse pièce [. . . ] où je leur dis que la flamme s'arrêtera au milieu des épis qu'elle dévore et que les fleuves remonteront vers leur source avant qu'on les voie porter de la mesure dans leurs désirs'": Properce ou les amants de Tibur, Grasset, Paris, 1928, p. 68). En la poesía castellana de los Siglos de Oro la referencia es tópica: "Antes rebuelba el paso presuroso/ desta elada ribera y claro rio,/ y nieue como agora en el estio/ y desampare Alcida a Nemoroso", se lee en un tronco, $R H i, 18$ (1908), p. 565, soneto 150 ; "Dejarán sus riberas, mar y río/ desnudos a sus peces. . ./ antes que yo conozca amor segundo" (HuRTADO DE MENDOZA, "Epístola XIII", ed. cit., p. 196); romances nuevos $(R H i, 65,1925$, p. 200; Fuentes, t. 2, f. 101); entre otros prodigios, "dejar su asiento este monte,/ volver atrás este río/ que desta alta sierra corre" (IUAN DE LA Cueva, en GallaRDo, op. cit., t. 2, p. 736); antes que Vandalio olvide, "la raudal corriente/ del Nilo volverá contra do corre" (BALTASAR DEL ALCÁZAR, manuscrito publicado por GaLLARDO, op. cit., t. 1, p. 75); "Primero que te olvide [sacro desierto mío de la Magdalena] volverán los ríos a sus fuentes y andarán por los montes los delfines" (PEDRO DE EsPINOSA, en el estudio homónimo de Rodríguez Marín, Tipografía de la Revista de Archivos, Madrid, 1907, p. 217); “ y las aguas de Ezla, y de Mondego, [podrán] con passo apressurado atras boluerse" (Diana de Alonso PÉREZ, en RENNERT, op. cit., p. 23, con la trad. de Yong -1598- en nota); "Bien posible será volver el río..." (Francisco DE MEDrano, "Oda primera", en BAE, t. 32, p. 344); con más imposibles, "el caudaloso río atrás volverse.../ antes que 
vuelva a colmo mi alegría" (DON GÖMEZ DE TAPIA, "Égloga en que se describe el Bosque de Aranjuez" en el Parnaso de Sancha, t. 3, pp. 264 y 265). Lo. PE se sirve con frecuencia de la comparación: "primero verás trepar/ contra su curso a la sierra,/ de unas pizarras en otras,/ las fuentes que bajan della" (La Arcadia, en Obras escogidas, t. 2, p. 500); "Podrá[n] volver atrás quantas corrientes/ al mar conducen caudalosos ríos... / ¡ó Amarilis! primero que las fuentes/ que precipita de los ojos míos/ aquel justo dolor, que de tu ausencia/ hace al partirse el alma competencia" (Amarilis, en el Parnaso de Sancha, t. 3, p. 60); "y así, cuando tú volver/ atrás su corriente veas,/ entonces quiero que creas/ que te dejo de querer" (El médico de su honra, en Obras escogidas, t. 2, p. 965, aquí con su burla). VILLEGAS también frecuenta el tópico: "y que atrás volvería/ este arroyuelo que estas hayas toca/ antes que el juramento. . " (" Oda X" en la ed. de Espasa-Calpe, Madrid, p. 64, y en la Floresta de BÖHL DE FA. $\mathrm{BER}, \mathrm{t} .1$, p. 317), y "este que vuela río. . / que parará no ignoro,/ que atrás volverá fío,/ primero que, cual luna,/ ya que sol me deseas,/ en mí mudanza veas/ y en ti no haya ninguna" ("Cantilena XXI", ed. cit. de Alonso Cortés, p. 218). La poesía popular no se queda atrás: colección de RoDríGuez MARíN, t. 3, p. 143, núm. 3455 y p. 227, nota 102; el Cancionero popular murciano de Alberto Sevilla, Impr. Suc. Nogués, Murcia, 1921, p. 237, núm. 959 ("que antes de fartarte yo,/ el río se güerve atrás"); el cancionero de ScHINDLER, Folk music and poetry of Spain and Portugal, New York, 1941, pp. 361 y 820 (lo cité en 1953, en mi primera colaboración a la $N R F H$ ), el cancionero de Extremadura de García Matos, p. 168, etc. Unas viejas peteneras publicadas en el siglo pasado por Guerrero ("Tu querer y mi querer,/ tu sentimiento y el mío,/ son como el agua del río,/ que atrás no pueden volver', p. 41) reaparecen en la Antologia gaucha de Ernesto Morales, El Ateneo, Buenos Aires, 1927 , p. 13) apenas variadas ("pensamiento" por "sentimiento", y "puede", en singular); y la 'Historia de la música argentina de Arturo C. SCHIANCA, Buenos Aires, s. a., p. 195, reproduce unas "Décimas de autor desconocido", la cuarta de las cuales comienza así: "Cuando una veloz corriente/ retroceda en su desvío...". El tema no falta en otras literaturas: CurTius (op.cit., p. 147) menciona un texto de Théophile de Viau que lo coloca entre otros presagios; y LEITE DE VASCONCELOS lo da en una composición popular portuguesa: "Hei-de-te vir a deixar/ onde o rio faz a volta...", Poesia amorosa do povo português, Viuva Bertrand-Suc. Carvalho, Lisboa, 1890, p. 123; no he podido ver el estudio de Edmundo Delgado Vivanco, El río en el folklore, separata de Letras, Universidad del Cuzco, Cuzco, 1948. Detenerse el curso del río (suceso no menos prodigioso que el hacerlo volver atrás) ha venido integrando, en la poesía popular, el oscurecimiento del universo provocado por la ausencia del ser amado: "Desde que no te he visto/ no he visto flores,/ ni los pájaros cantan,/ ni el río corre" (SchindLER, Cancionero, núm. 820; cf. la colección de RoDRÍGUez Marín, t. 3, o. 14, núm. 3455): imita con prudencia este sentir PALACIO Valdés en Los majos de Cádiz, Espasa-Calpe Argentina, Buenos AiresMéxico, 1947, p. 102: "Desde que saliste de casa, ni cantan los pájaros en la jaula, ni huelen las flores en el balcón, ni el perro hace otra cosa todo el día que aullar...'. El mismo portento, venido de las Escrituras, resuena en escritos religiosos: con la Presentación, "Vuelve la Virgen su depósito al mesmo Señor que se lo había encomendado: y corren los ríos al lugar de do salieron, para que vuelvan á correr"' (Fray LUIS DE Granada, Meditaciones muy de- 
votas, $B A E$, t. 8, p. 523 ; la nota $g$ remite a "Eccle. 1", o sea a Ecclesiastes 1, 7: "Omnia flumina intrant in mare, \& mare non redundat: ad locum, unde exeunt flumina, revertuntur ut iterum fluant". Y el Jordán remonta, bíblicamente, del Espéculo de los legos ("E aun el río Jordán tornó atrás contra natura a la fuente del su nascimiento", ed. Mohedano Hernández, p. 475, Estoria de la fiesta del Cuerpo de Dios) a François Mauriac ("Un homme converti devrait nous donner le même étonnement qu'un fleuve qui retourne vers sa source: Jordanis conversus est retrorsum", La vie de Jean Racine, Pion, Paris, 1928, p. 236: la cita repetida procede del salmo 113 , versículos 3 y 5).

${ }^{58}$ Cervantes, La Galatea, ed. Avalle-Arce, t. 1, pp. 99 y 102.

${ }^{59}$ En Menéndez y Pelavo, Origenes de la novela, t. 2, pp. 463-464.

60 Bernardino Baldi, La Nautica e le egloghe, con prefazione e note di Girolamo Romeo, Carabba, Lanciano, 1913. "Égloga XV", vv. 155-239, pp.189-191.

${ }^{61}$ Aquélla repercute todavía bajo la pluma de JACQues-Émile BLANCHE: "le coeur saigne avec la vigne blessée" (carta a François Mauriac del 23 de septiembre de 1933, p. 172 de su correspondencia). El árbol personificado de $L$ 'enfant et les sortilèges gime repetidamente, gracias a Colette y a Ravel: "Ma blessure! ma blessure!"

62 Habla Leuridemo, en El premio de la hermosura; Décimasexta parte de las comedias de LoPe DE VegA, Madrid, por la viuda de Alonso Martín a costa de Alonso Pérez, 1622, f. 11

${ }^{63}$ LÓPEz DE ZÁrATE, "Égloga elegiaca”, ed. cit., p. 285; modificamos la puntuación.

${ }^{64}$ Quijote, II, Ixxiii.

${ }^{65}$ Quijote, I, xii. En la ed. de Espasa-Calpe, t. 1, p. 275, nota a línea 7, Rodríguez Marín lee "alguna" y anota: "Por el sentido, este alguna debe referirse a corteza y no a haya. Sea lo que fuere, aquí parece estar viciado el texto". Efectivamente, no es "alguna" sino "alguno", que se refiere a "nombre", y así lo imprime su edición póstuma, t. 1, p. 344, cuya nota a línea 12 recoge la corrección de Hartzenbusch a la vez que se apoya en un pasaje del Pedro de Urdemalas: ". . .que no hay haya en aquel prado/ donde no te vea escrita,/ y tu nombre coronado... ". - Escrito este pasaje, encuentro al repasar La'Arcadia de Sannazaro la siguiente reflexión de Scherillo: "II Cervantes però, facendo parodia dei suoi compatrioti, la faceva specialmente di sè stesso: chè negli anni giovanili aveva scritto la Galatea, un dei più lunghi romanzi pastorali benchè incompleto" (p. CCLI). Y precisamente a propósito de La Galatea, BRU. NA CinTI recuerda el pasaje paralelo del Coloquio de los perros con la burla "di tutti i componimenti pastorali ... per bocca del cane Berganza", "Da Castillejo a Hernández. Introduzione"' a su trad. de La Galatea, Bulzoni, Roma, p. 81.

${ }^{66}$ Quevedo, El Buscón, ed. de Américo Castro - "nuevo texto" de 1927-, p. 123; la rechifla, voz no impertinente, llega al "Salicio usaba tañer..."

${ }^{67}$ Romancerillos italianos publicados en la $R H i, 45$ (1919), p. 590, y 65 (1925), p. 212.

${ }^{68} B A E$, t. 42, p. 61

${ }^{69}$ De Sanctis, en la Storia della letteratura italiana, Laterza, Bari, 1925, t. 1, p. 302, señala la función del idilio como "prima forma nella quale si manifesta questa generazione... colta ed erudita" de la que es espejo Boccaccio en su Nenfale. Y es precisamente esta condición de "pura materia de arte" que 
se manifiesta ya desde Virgilio, esta condición de producto "convencional" - esto es, adaptable a diferentes circunstancias locales - lo que determina la exitosa difusión europea del género, según la reseña que de él hace GiUSEPPE FINZI en sus Essais de littérature italienne, Perrin, Paris, 1924, que citamos por las pp. 57 y 56 de su cap. 2, "L'Arcadie allemande". Idéntico sonido en GerHARDT, p. 300: "Tel est le genre pastoral, qui ne repose sur rien d'autre qu'une décision artistique de la part du poète. Ce n'est pas la nécessité intime qui le crée, mais l'intention et la préméditation littéraire" (cursivas originales).

${ }^{70}$ Orígenes. .., t. 2, p. 561.

${ }^{71}$ Aunque no falte por completo su media ración de griegos, y Virgilio sea más bien latino, dice verdad H. CASTONNEt Des Fosses: "sans remonter jusqu'aux Grecs et aux Latins, Virgile a trouvé de nombreux imitateurs chez les Italiens et les Espagnols" (La poésie pastorale portugaise, Lachèze et Dolbeau, Angers, 1886).

72 Égloga V, Mopsus, vv. 13-15, p. 46 de la ed. cit.

${ }^{73} B A E$, t. 37, p. 22.

${ }^{74}$ Compárese con su versión en prosa: "Si no fuere nada de esto, vere que te parece vnos versos, los quales poco ha dexé escritos en la corteza de vna verde Aya, y los tengo bien en la memoria; porque los he cantado muchas vezes, ya con el instrumento, ya sin él...". Los dos textos de Fray Luis aparecen en las pp. 152 y 98 del Tomo primero de las Églogas [falta la coma entre "primero" y "de"] de las Obras de Publio Virgilio Maron. Concordado. En latin artificial, en latin natural, en lengua castellana, de prossa, y verso, y en notas latinas... por el lie. Abdias Ioseph, natural de Cedillo... (En Madrid, por Domingo Garcia Morràs, vendese en casa de Iulian Hernandez, 1660). MAYANS y SISCAR, en la p. 51 de su vida de Virgilio, reproducida en el t. 1 de Todas las obras de Publio Virgilio Maron. . (Valencia, en la oficina de los hermanos de Orga, 1795), donde trata de algunas de las traducciones castellanas del mantuano, presenta a este Joseph Abdías que "transformado en Antonio de Ayala, en el Prólogo del segundo tomo, donde imprimió las Geórgicas..., confessó lo que sigue: los versos castellanos son sacados a la letra de los libros de aquel insigne Varon (sigue el elogio de Fray Luis), salvando parcialmente - la prosa no se menciona - el plagio del tomo primero.

${ }^{75}$ Las Eclogas, y Georgicas de Virgilio, y Rimas, y el Pompeyo tragedia de Christoval de Mesa... En Madrid, por luan de la Cuesta, 1618, f. $13 \mathrm{v}^{\circ}$. - JUAN DEL Encina, Égloga $V$; f. xxxix de la ed. facs. de su Cancionero. Sobre su traducción de las églogas de Virgilio, véase Roland M. MaCandRew, "Notes on Juan del Encina's Eglogas trobadas de Virgilio", $M L R$, 34, 454-458, trabajo que no figura ni en la Bibliografía ni en el Manual de José Simón Díaz.

${ }^{76}$ La traducción de Diego López (VIRGILIo, Las obras... .) fue publicada en Madrid, por I. de la Cuesta, a costa de M. Martínez, 1614; p. 9. El comento va en las pp. 21-22: “experior, \&c como si dijera, antes experimentaré aquellos versos, que poco ha escribí en la verde corteza de la haya, y no de encina, cuya corteza es áspera, escabrosa, y inútil para escribir, y por lo contrario la corteza de la haya es más suave, porque es semejante a la del álamo, en la cual fácilmente se escribe". En muchas traducciones francesas "hêtre", (desde $\mathrm{P}^{* * *}$ [Perry], Les Bucoliques..., Paris, chez Claude Barbin, 1689, p. 33) suscita su correspondencia "champêtre"; y quizás para sacudir esta tiranía, o por una falaz fidelidad fitogeográfica, Didot (Les Bucoliques..., Paris, à la 
librairie de Firmin Didot, 1806, p. 148), Tissot (Bucoliques..., $3^{\mathrm{e}}$ éd., Delaunay, Paris, 1812, p. 167, y $4^{\mathrm{e}}$ éd., ibid., 1822, p. 171), y Marcel Pagnol (Bucoliques..., Bernard Grasset, Paris, 1958, p. 107), se mudan de tronco y domicilian sus versos en un "frêne", licencia que ni el latín ni Linneo autorizan. Sea como fuere, el preciso árbol latino ha suscitado entusiastas defensores: Leonel da Costa (As Eclogas, e Georgicas de Vergilio..., impresso por Geraldo da Vinha, Lisboa, 1624, p. 20) remezcla esta égloga quinta con la primera para identificar a Mopso con el propio guía de Dante: “diz que os screuo na cortiça da faia, sub cortice fagi [sic]: isto he daquella aruore, debaixo da qual o poeta estaua recostado: \& assi se ha tomar aqui Mopso por Vergilio''. JEAN Giono sostiene, contra la frenesia de los fresnos, la supremacía de lo poético sobre la realidad: 'De sérieux alpinistes ont beau prétendre qu'il n'y a pas de hêtres à Mantoue et même fort loin de Mantoue et que, cependant, le menteur a écrit sub tegmine fagi. Non. Ici il les a mis à côté de son Mincio frangé de roseaux, et c'est lui qui a raison. [...] Et l'autre qui s'obstine au nom de la raison et d'on ne sait quoi de scientifique à prétendre que les hêtres ne poussent qu'à partir de 1100 mètres. Non mon ami! Sub tegmine fagi où que je sois, même au fond de la fosse des Kourilles. Voilà la poésie!" (Les pages immortelles de Virgile. .., Eds. Corrêa, Paris, 1947, pp. 14-15): la consagrada sombra del haya seguirá albergando poetas, de Torres Villarroel ("Debajo de una haya, Músico,/ bien toca la flauta Títiro...", "Romance" (pronóstico y esdrújulo) en los Juguetes de Talia, t. 8 de sus Obras, Imprenta de la Viuda de Ibarra, Madrid, 1795, p. 281, al Valle-Inclán de Voces de gesta y a Darío, "bajo el frescor del haya... como en Virgilio"' (Alan S. TRueblood, "El "Responso a Verlaine" y la elegía pastoril tradicional", $C H(3)$, p. 864). Un caso excepcional es el de la versión de Charles Millevoye (Les Bucoliques de Virgile, traduites en vers français... Chez $\mathrm{H}$. Nicolle [de l'imprimerie de Mame frères], Paris, 1809) que en la p. 59 vierte así, separándose de la tradición que nos ocupa y cambiando el papel del haya virgiliana: "Je te dirai plutôt ces vers que, l'autre jour, / je traçais sous un hêtre et chantais tour à tour..." Las palabras finales de la declaración de Mopso no son absolutamente cristalinas (testigo, las muy diferentes maneras de trasladarlas adoptadas por los diversos traductores); pero su examen detallado, de carácter estrictamente musicológico, requiere una atención - y una extensión- que no pueden encontrar su sitio aquí.

77 Parnaso de Sancha, t. 7, p. 83.

78 "Elegía", ibid, , p. 86.

79 Así lo llama LoPE en su "Égloga a Claudio". ibid, p. 107 mal numerada " 017 ".

${ }^{80}$ JULIEN BENDA (op.cit., p. 136) da en francés todo el pasaje ("Je vous en fais témoins, ô vous hêtres, ô vous pins chéris du dieu d'Arcadie, si l'arbre connaît aussi l'amour (si quos habet arbor amores), combien de fois vos ombrages ont retenti de mes plaintes, que de fois ai-je écrit le nom de Cynthie dans votre écorce?") y recuerda además a "Chénier, tout nourri de ces poèmes, adorateur des arbres "où Cynthie est écrite en l'écorce odorante»" (p. 164). A propósito de la frecuencia con la que Propercio se sirve del topos, Maurice Rat, en su edición de Virgilio, anota la égloga décima (p.230) incluyendo una referencia a Ovidio ("Héro[1d.23") y a "Properce, passim". Los textos de Propercio se leen en las Oeuvres complètes d'Horace, de Juvenal, etc., avec la traduction en français, publiées sous la direction de M.Nisard, Didot, Paris, 1883; p. 458 
para la "Elegía XVIII", vv. 21-22 citados.

81 Véase CalPurnio, I, "Delos", vv. 20-21: "Sed quaenam sacra descripta est pagina fago,/ quam modo nescio quis properanti falce notavit?"; III, "Exhoratio": "cerasi tua cortice uerba notabo,/ et decisa feram rutilanti carmina libro"' (vv. 43-44: "Grabaré tus palabras en la corteza del cerezo, y llevaré los poemas separados en la brillante corteza", trad. de María Rosa Lida), "Hi tamen ante mala figentur in arbore versus", v. 89; IV, "Caesar", v. 130: "Et cantus viridante licet mihi condere libro"' (en Stace, Martial, Manilius, Lucilius Junior, Rutilius, Gratius Faliscus, Némésianus et Calpurnius, oeuvres complètes avec la traduction en français, publiées sous la direction de M. Nisard..., J. J. Dubochet et compagnie, Paris, 1842, pp. 807, 812, 813 y 816; también en el Corpus poetarum latinorum, ed. John Percival Postgate, J. Bell \& Sons, London, 1905, t. 2, pp. 197 ss.). -Nemesiano: "accipe quae super haec cerasus, quam cernis ad amnem,/ continet, inciso seruans mea carmina libro", (NÉmÉsIEN, Oeuvres, texte établi et traduit par Pierre Volpilhac, Les Bèlles Lettres, Paris, 1975, p. 43, vv. 28-29). Inútil señalar que los poetas latinos muy tardíos continuarán la tradición incisoria; baste un solo ejemplo poco transitado, de F. Duyckius: "lili sylva domus: sylvis hic gaudet opacis,/ et dominam solis scribit in arboribus" (p. 5 de: Amplissimi Viri Franconis Dvyckii Comparatio elegans venatoris et amatoris. Edita ex Museo Ioachimi Mors. . Ludguni Batavorum, excudebat Iacobus Marci, 1619, p. 5). El cerezo, propicio a grabadores como el peral, muestra su divisa en un romance nuevo: "Ya que las huertas possaua/ vio tallada en vn cereço/ vna muerte y esta letra:/ Ausente me desespero' (Fuentes, t. 4, f. $28 \mathrm{v}^{\circ}$; el Romancero general, ed. Huntington, f. 95 $\mathrm{v}^{\mathrm{o}}$, corrige "passaua").

${ }^{82}$ Curtius (op. cit.), sobre la mención de p. 468 que recordaremos más adelante, desarrolla en la p. 474 la mención de esta práctica, citando el Orlando furioso, a Calímaco, a Propercio, y la escena segunda del acto tercero de Como gustéis. La lista de autoridades clásicas es muy inferior a la que siglos atrás proporcionaba La Cerda en su edición citada de Virgilio (notas 4 y 5 de la p. 177): "Theocrit. in Epithal. Helenae. . Lucianus \&̊v है citado por el escoliasta de Aristófanes según la versión latina de Erasmo; en cuanto a los latinos, "indico illos, ne cogat multos transcribere. Vide itaque Ouidium in Oenone, Propertium Lib. I eleg. 18. Titum Calpurnium. $1 \& 3$. Ecl. Veteram Poetam ad Lipsium, I. Elect. cap. 5. Angelium. 1 \& 2. Ecl." María Rosa Lida de Malkiel, en $R P h, 5$ (1951-1952), p. 130, nota 33, rebate la justeza de la nómina propuesta por Curtius: "entre los precedentes de grabar el nombre de la amada en las cortezas de los árboles (p. 340 de la ed. alemana) no hacen al caso la Cidipa de Calímaco y sí lo hacen los omitidos Virgilio, Égloga $X, 55$, y Ovidio, Heroidas, V, 20 : «incisa seruant a te mea nomina fagi"" (texto retomado en el volumen póstumo, sin variantes, pero convertido en la nota 35 de la p. 329). El pasaje completo de Ovidio reza, en traducción de María Rosa Lida: "Las hayas, grabadas por ti, conservan mi nombre y me leen "Enone", marcada por tu hoz. Mi nombre crece tanto como los troncos: creced, y alzaos erguidos para servirme de inscripción. Hay un álamo - lo recuerdo- plantado junto a la corriente de un arroyo, y en él está escrita una letra que recuerda nuestro amor. Álamo, vive, te lo ruego, tú que plantado al borde de la ribera tienes estos versos en tu rugosa corteza: "Cuando Paris tras abandonar a Enone pueda respirar, el agua del Janto correrá rum- 
bo a su fuente"". La influencia de Ovidio en las letras castellanas ha sido brillantemente estudiada por Antonio Alatorre en un trabajo hoy desdichadamente fuera de mi alcance; permítasenos recordar alguna resonancia de la heroida ovidiana, a riesgo de repetir lo ya dicho: puede ponerse a la cuenta de Ovidio este pasaje de la "Égloga II" de Diego Hurtado de Mendoza, traductor de la epístola de Dido a Eneas: "En tu ribera hay un olmo en que escrebí/ su nombre y [con?] el mío juntamente,/ y mi [un?] verso que debajo dice así:/ "Testigo me sea el cielo omnipotente,/ que cuando Damon viva sin Marfira,/ Tamisa correrá contra su fuente"'. La epístola, traducida por Diego Mejía de Fernangil, figura en la p. 5 de Las cien mejores poesías (líricas) peruanas. Siglo $X V I$ a XX, coleccionadas por Manuel Beltroy, Euforión, Ciudad de los Reyes del Perú, 1921. Y "de la obra de Diego Mexía, Primera parte del Parnaso Antártico de obras amatorias (Sevilla, 1608), y acaso también de otras análogas", según su editor (p. xliii) la toma Lozano: “ ¿Son éstas las finezas que me vendías cuando en los troncos de los árboles escribías mi nombre? Y en especial me acuerdo que en un álamo, plantado a la orilla del caudaloso Xanto, escribiste este mote mentiroso: "Cuando a la hermosa Enone olvide Paris y él viviere, dejándola olvidada, volverá atrás este río su corriente». Ea, pues, Xanto, vuélvete atrás, refrena el curso cristalino; volved, aguas, vosotras, a ver una fe rompida, pues Paris está viviendo, cuando me ha olvidado ingrato" (Historias $y$ leyendas, Espasa-Calpe, Madrid, p. 162). Y, si no me engaño, el recuerdo de la heroida se apunta desde los orígenes de la poesía culta castellana: Alejandro Magno hubiera buscado las huellas de esta dolorida pasión, según el ms. $P$ de su viejo poema: "Tanto pudo el rey la cosa acuciar/ fasta quel ouo el arbol a fallar/ do escriuio Cenodes dos viersos vn buen par/ quando disien que Paris lo auje de dexar"' (p. 311); los copistas no restituyen bien el nombre de la abandonada, y ni siquiera aciertan con su sexo: en P a "Cenodes"' corresponde un "lo" y en O va reemplazado por Diomedes, complicando la historia con el abandono de Helena (vv. c-d de la copla 304: "do escreuio Diomedes de viersos un bon par/ quando dizen que Paris a Elena ouo a dexar").

${ }^{83}$ Té́crito, "Epitalamio de Helena", vv. 44 y ss.; trad. María Rosa Lida. La colección de bucólicos griegos publicada por Ph.-E. Legrand (Tome I. Théocrite; tome II. Pseudo-Théocrite. Moscos. Bion. Divers, Les Belles Lettres, Paris, $1972-7^{\circ}$ tirada del t. 1- y 1927) explica en su traducción el miembro de frase omitido (" al modo de los dorios") referido a la inscripción: "Ge qui est «à la mode dorienne ce n'est pas l'existence d'une inscription gravée sur l'écorce d'un arbre: c'est, je crois, ce qu'exprime l'inscription: l'invitation à rendre culte à cet arbre, l'élévation d'un arbre à la dignité d'objet sacré"'. El plátano también se ilustra con un nombre querido en "La métamorphose", quingentésima octava de las Canciones de Bilitis: "Je me souviens d'avoir gravé un nom dans l'écorce d'un platane", reminiscencia segura de Teócrito. Y también, como en Roma, otros poetas menores se servirán del tema: Glauco (siglo II de la era vulgar) anota el diálogo de Pan y las ninfas: "Pan: Ninfas, responded exactamente a mi pregunta. ¿Ha pasado por aquí Dafnis haciendo descansar sus blancas corderas? - Ninfas: Sí, sí, Pan, tocador de zampoña; y en aquel álamo grabó en la corteza unas letras que te dijeran: «Pan, Pan, ve a Malea, al monte Psofidio, que allá iré». - Pan: Adiós, Ninfas. Yo me retiro". Una vez más, gentileza y traducción de María Rosa Lida. (El texto se lee en los Epigrammatum, Anthologia Palatina, Didot, Paris, 1888, t. 2, pp. 68-69). 
${ }^{84}$ Trillo y Figueroa, "Romance VII", imitación de la oda de Anacreonte "Cantem libens Atridas", $B A E$, t. 42, p. 58: “ $\mathrm{O}$ Oh dulce beso lascivo!/ ¡Oh quién de Baco pudiera/ grabarle en las dulces vides/ por acrecentarle en ellas!"

${ }^{85}$ Diego López es literal: "Tengo determinado... esculpir mis amores en los tiernos árboles, crecerán ellos y creceréis vosotros, amores" (ed. cit., p. 20). Fray Luis, literal en su versión en prosa ("escribiré mis amores en los tiernos árboles: crecerán también mis amores", ed. cit. de Mayáns, p. 177), enriquece, como JUAN DEL ENCINA ("y mis amores porne/ en los arbores mas bellos/ yran creciendo con ellos/ los amores y la fe", Cancionero, fi xlviij), su traducción en verso: "Entallaré en los árboles aquesto,/ y tu quebrada fe, Licori, y vana;/ ellos creciendo se harán mayores,/ y creceréis con ellos mis dolores" (id., p. 184; en $B A E$, t. 37, p. 25, hay una razonable coma antes de "'mis dolores"'); Maurice Rat (Les Bucoliques et les Georgiques. .., Garnier, Paris, 1932, también evoca a "Lycoris", pero en la nota 310 de la p. 230, en la que remite a Propercio y a Ovidio. Mayáns da también, en su p. 191, la amplia traducción de Juan de Guzmán: "Allí en la tierna planta el nombre amado/ de los amores míos escribiendo,/ sin contar de los otros el cuidado./ Mas no, que estas se irán grandes haciendo,/ y vosotros amores junto en ellas/ así tratados, junto iréis creciendo"'. La contraria versión de Cristóbal de Mesa, al sucintarse, frisa las verdades de Pero Grullo: "y en árboles escritos mis amores,/ quanto crecieren más, serán mayores"' (Parnaso de Sancha, t. 1, p. 223, o $B A E$, t. 42, p. 511). La uniformidad de las traducciones francesas, que en la égloga quinta corren por diferentes rumbos, sólo se altera por el añadido de leves notaciones, procedentes algunas de imitadores: Tissot (p. 302 o 305) aporta anónimamente (¿modestamente?) lo que "Un autre a dit: Jeuns pins, vous croîtrez; tu croîtras, mon amour"; Lauwereyns de Diépennède (Les Bucoliques de Virgile. . ., Librairie Classique, Paris, 1831, p. 197) transcribe la paráfrasis de Segrais: 'J'ai gravé son beau nom sur l'écorce des hêtres,/ sans qu'on s'en aperçoive, il croîtra chaque jour; hélas! sans qu'elle y songe, ainsi croît mon amour"'; Henry des Abbayes (Les Bucoliques... ., Latomus, Bruxelles, 1966) sugiere "l'écorce d'un tremble" en la que amores y árbol podrán "croître ensemble" (Ronsard, que en su Chant pastoral aplica la imitación virgiliana a indiscriminados "arbres verts" - "Et par mille beaux vers/ son nom croistra dedans les arbres verts/ qui gardoient dans l'ecorce entamee/ a tout iamais sa viue renommee, / pour deuenir plus vielle quelque iuor/ que ces rochers plantez tout à l'entour", repitiéndose en "Grauez le en votre escorce, à fin que tous les mois/ il croisse comme vous" -, en Hélène elige el pino, que "est arbre de Cybelle", para que sus nombres y amores crezcan con "l'escorce nouvelle"). La unanimidad de las traducciones se corrobora por la de los comentadores, que en esta égloga se limitan a ilustrar el adjetivo "calcídico", ausente del diccionario en su acepción poética pero usado por Lope de Vega (tales Iodoco Vuiluichio, Scholia posteriora, in P. Virgilii Maronis Bucolica [etc.], Basileae [oero loannem Oporinum, s.a.], o. 149 de la $1^{\text {a }}$ paginación; o E. GLASER en su tesis Publius Vergilius Maro als Naturdichter und Theist-Kritische und ästhetische Einleitung zu Vergils Bukolika und Georgika, Druck und Verlag von C. Berteismann, Güersloh, 1880, p. 145). Tan sólo Juan Luis Vives (alentado quizás por el ejemplo pregutenberguiano de Calournio) explica el "Teneriso ${ }_{3}$ meos in cid" [sie] como "Poematis madare amores meos, qui crescent simul cum 
ipsis carminibus" (Opera..., Basileae, Anno mDLv; texto fechado en "Bredae Brabanticae, anno 1537').

${ }^{86}$ MONTEMAYor: “¿No queda aquí la historia/ en la certeza [sic] dura/ escrita de su mano,/ y crecen a una mano/ las letras, el dolor, la desventura?" ("Égloga tercera", Cancionero del poeta George de Montemayor, Sociedad de Bibliófilos Españoles, Madrid, 1932, p. 461); De LA TORRE: "plantas que vais al cielo enderezadas. . . / crezca en vuestra corteza/ mi nombre y mi firmeza" ("Égloga segunda", ed. cit., p. 119); JUAN RUFo: "En las plantas, por mil vías/ se entalle y fije la historia;/ y, creciendo con los días/ las arboledas sombrías,/ crezca también la memoria" ("Elegía en la muerte de Doña Ana de Toledo", ed. cit., p. 316); Pedro de Padilla: "En vn olmo escreui vn dia,/ crezca la firmeza y fe,/ y despues quando torne,/ vi como crecido auia:/ pusome gran confusion,/ que en la siluestre corteza,/ crezcan la fe y la firmeza,/ y no en vuestro coraçon" (Tesoro de varias poesías, Madrid, por Querino Gerardo, a costa de Blas de Robles, 1587, "Canción agena con Glosa propia", f. 147 $\mathrm{v}^{\mathrm{o}}$-148); JERÖNIMO de Lomas CanTORAL: "y en los troncos de más lustre/ de los árboles más bellos,/ porque crezca bien cual ellos/ escribo tu nombre ilustre"' (Las obras poéticas, Madrid, 1578, f. 30; en la Floresta de BöHL DE FABER, t. 1, p. 234, núm. 120); Gutierre de Cetina: "Crezcan a par del olmo en su grandeza/ las letras del amado y dulce nombre" ("Égloga", en el Parnaso de Sancha y en $B A E$, t. 33, p. 40); Pedro de Salas: "que en los árboles tiernos/ mis amores eternos/ escribirá en estilo muy galano.../ como fueren los árboles creciendo/ los nombres enlazados/ irán con ellos y mi amor subiendo/ hasta verse en su cumbre coronados" ("Afectos divinos", en BöHL DE FABER, t. 3, p. 68, núm. 718); Trillo y FigueroA: "De un robre duro en la tenaz corteza/ Daliso el nombre de su Fili había/ grabado con su fe, donde crecía/ al paso que crecía su firmeza..." y "Ya tu dulce nombre,/ como ha tiempos tantos/ que en fecundos troncos/ le escribió mi mano,/ con las ramas crece", ("Soneto XIX" - cf. el "Soneto III"' citado en la nota 49-, y "A una dama ausente. Sobre el lugar de Virgilio: Ne lacrimis crudelis amor, etc." - aquí la hiedra cubre la inscripción-, en $B A E$, t. 42, pp. 47 y 48); PRínCIPE DE EsQUILACHE: “Qué tronco en el papel de su cortezal no mostró la verdad de sus amores?/ ¿Qué rústicos pastores/ en ellos no leyeron su firmeza? / Y ésta, que en mí no hay tiempo que la rinda,/ creció en las letras y menguó en Lucinda" ("Égloga I", comunicada por María Rosa Lida; en el Parnaso de Sancha, t. 9, p. 251); Cervantes: "Las letras que fixaré/ en esta aspera corteza,/ creceran con mas firmeza/ que no ha crecido tu fe" (La Galatea, ed. Schevill-Bonilla, t. 1, p. 88); LOPE: "Quiero de Albania al resplandor divino/ consagrar de improviso un Epigrama/ con aqueste cuchillo en este pino/ porque crezca su nombre, gloria y fama/ en las orillas del anciano Tormes...", "Pues no hay álamo en el prado/ sin letras de mi cuidado,/ para que crezca mi fe" y "yo en árboles y riscos escribía./ Seméjanse mis letras a mis penas,/ que van creciendo mas cuanto mas vivo"" ("Égloga" en el Parnaso de Sancha, t. 7, p. 143: "nombre"' puede significar 'renombre'; "Servir a buenos" en $B A E$, t. 34, p. 434: gentileza de María Rosa Lida; y "Égloga amorosa" en BAE, t. 38, p. 307); y Quevedo: " "Oh vos, troncos, anciana compañía,/ de humilde soledad verde y sonora!/ Pues escritos estáis de la porfía/ de tanto amante que desdenes llora,/ creced también la desventura mía" (en la $1^{\text {a }}$ ed. de Blecua, p. 405, núm. 387; el Parnaso de Sancha, t. 4, p. 186, toma este "Idilio I" de El Parnaso español, ed. 
de 1729, t. 1 - "primera cumbre"-, p. 235). Las letras en el árbol pueden crecer mudadas, no en firmeza, y quizás no supiera que decía tan bien el anónimo glosador de la canción "De los álamos vengo, madre": "Escribió por la corteza/ de estos álamos su fe,/ y, aunque crecida se ve,/ es mudanza y no firmeza" (en Cejador, La verdadera. .., t. 6, núm. 2466, pp. 71-72: la toma de la $R H i, 39,1913$, p. 183, y opina: "Parecería que faltase esta copla en el Laberinto amoroso, 1618'). Crecer, en ciertas cortezas, puede tornarse sinónimo de borrar: ÉMILE HENRIOT cierra así la suerte del árbol estigmatizado durante la ocupación alemana: 'J'avais condamné l'arbre, dans mon esprit: il fera des bûches, à mon retour. . . Je suis allé le voir. C 'est un beau hêtre rouge, planté par mon père, il y a trente ans. J'avise l'inscription, la gravure: mais déjà l'ecorce, en se développant, l'a rompue et l' efface presque. Laissons vivre l'arbre. Il n'y peut rien. Dans deux ans, l'offense ne paraîtra plus, la nature et le temps auront enlevé la souillure..." (Naissances, pp. 233-234). Ya lo había previsto el lacrimoso amante de la "Égloga" citada de Figueroa: "La tierra se humedece,/ y en su mayor dureza,/ con mi llorar los árboles levanta,/ y juntamente crece/ tu nombre en su corteza,/ el tierno humor las letras dél quebranta..." (Parnaso de Sancha, t. 4, p. 96). Contra lo que afirman los que describen las inscripciones en el ombú, mi experiencia sostiene que en él "el tierno humor" quebranta letras y figuras.

${ }^{87}$ Ed. cit., p. lxxxi del prólogo. No es ocioso levantar las notas del texto: p. 18 "Questi alberi di lei sempre ragionano,/ e nelle scorze scripta la dimostrano", vv. 103-104, y nota de p. 17 a los vv. 91-106: "Prop. I, 18: . . Scribitur et vestris Cynthia corticibus! [etc.]"; p. 40: entre las pinturas del templo figuraba Paris, "che con la falcie havea cominciato a scrivere Oenone a la corteccia de un'olmo, et per giudicar le ignude Dee, che dinanci li stavano, non la haveva potuta anchora del tutto fornire", y nota a las líneas 111-115: "Cfr. Ov. Her. V, 21 ss.: Incisae servant a te mea nomina fagii et legor Oenone falce notata tua"; p. 51: "per questo io scrivo et vergo/ i faggi in ognie boscho,/ tal che omay non è pianta/ que non chiama Amaranta", vv. 59-62, y nota a éstos, donde vuelve a citar "Ov. Her. V. 21" y "Prop., I, 18"; y p. 77: "trovaremo molti alberi, nei quali io un tempo, quando il sangue mi era piú caldo, con la mia falce scrissi il nome di quella che sovra tutti li greggi amai, et credo giá che ora le lettere insieme con gli alberi siano cresciute; onde priego gli Dii che sempre le conserveno in exaltatione et fama eterna di lei": la nota a las líneas $72-82$ remite a las "pp. $17-18$ e passim. Ov. Her. V. 21 s. . . Virg. Egl. X, 51-9 . .", única - se non sbaglio- mención de Virgilio, a mal grado de lo que el prólogo afirma. A propósito de esta "Prosa V" ya Thomaso Porcacchi, erudito anotador de la edición veneciana de 1583 que me inició en Sannazaro, relacionaba las palabras de Opico con la última égloga de Virgilio.

${ }^{88}$ Unos pocos ejemplos aportados por SCHERILlo: "Or vogli, Astreo, per li gran trunchi scrivere/ el parlar mio" (P. J. de Jennaro, p. 343, Appendice V. ms. de la Bibl. Naz. di Napoli; "Or per li tronchi et per li sassi scrivolo" (Anónimo, p. 328, Appendice II, de la misma procedencia: cf. "Legga per queste querce, \& per li sassi,/ che n'è già piena ormai ciascuna valle", Arcadia, égloga IV, p. 71 de la ed. de 1583. Pero más que contagio de poeta a poeta, la operación parece endémica en los siervos de Apolo, como lo manifiesta micer Vicenzo Marostica: "Io parimente, che d'Apollo seruo,/ son, Muse, e Cigni 
sempre in sogno veggio,/ e ne i tronchi de i Lauri hinni disegno"' (Venezia trionfante... In Venetia, apresso D. Farri, 1572, p. 1).

89 Joseph G. Fucllla, Relaciones hispanoitalianas, trad. Manuel de Ezcurdia, Madrid, 1953 (Anejo LIX de la $R F E$ ). Véanse "Ecos de Sannazaro y de Tasso en Don Quijote", pp. 27-37; “'Gii Polo y Sannazaro", pp. 63-70; “'Sobre Ia Arcadia de Sannazaro y El pastor de Fílida de Montalvo", pp. 71-76; “"El Siglo de Oro de Bernardo de Balbuena y sus fuentes", pp. 77-79; "Fortuna española de un terceto en la Arcadia de Sannazaro", pp. 100-104, ya citado.

${ }^{90}$ La fingida Arcadia, ed. de los Ríos, t. 2, p. 1410; "Arcadia"' es voluntariamente ambiguo.

${ }^{91}$ Héctor Genouy, L" "Arcadia" de Sidney dans ses rapports avec l" "Arcadia" de Sannazaro et la "Diana" de Montemayor, thèse complementaire présentée à la Faculté des Lettres de l'Université de Lyon, Montpellier, 1928, p. 59.

92 TAsso, Aminta, favola boscareccia, Fili. Borsi, Parma, 1765, textos rev. en la ed. moderna "con introduzionie e commento di Carmelo Previtera", Vallardi, 1936; la primera cifra remite a la ed. más antigua. Aminta, fábula pastoral del Torcuato Tasso, traducida por don Juan de Jáuregui, edición esterotípica de la Real Academia Española, Madrid, 1804; también en $B A E$, t. 42: idéntica advertencia para la doble paginación. Los pasajes apuntados son los siguientes: "Lo scrisse in mille piante, e con le piante/ crebbero i versi...", Acto I, esc. 1, vv. 227-228, p. 16 o 46; "El escribió mil troncos, y con ellos/ creció la letra juntamente, y versos", p. 14 o 134. - “Ch'è ben ragion ch'io lasci chi ridica/ la cagion de'l morire, e che l'incida/ ne la scorza d'un faggio, presso il luogo/ dove sar sepolto il corpo esangue", Acto I, esc. 2, pp. 21 o 49-50; "Que me importa dejar quien manifieste/ de mi morir la causa, y que la imprima/ en la corteza de una haya infausta,/ junto al lugar do yacerá mi cuerpo", p. 17 o 135. - "E perderan le rime...", final del coro intermedio entre los actos II y III, p. 45; "Y humillará sus versos/ el más alto poeta. . ./ junto a los que imprimiere/ mi pastoril rudeza/ con la grosera mano/ en áperas cortezas", p. 49 o 141: justificado tributo al poemio de Sannazaro.

93 TASsO, VII, vv. 19-22: "Sovvente, allor che su gli estivi ardori/ giacean le pecorelle all'ombra assise,/ nella scorza de'faggi e degli allori/ segnò l'amato nome in mille guise" (I quattro Poeti italiani con una scelta di poesie italiane... Lefêvre, Paris, 1836, p. 659); "En tanto cursas, Fátima, el oficio/ de repastar cuidados entre cabras, / al bosque vas, y allí con artificio/ de un árbol y otro las cortezas labras", PEDRO DE OÑA, El Vasauro, editado por primera vez por Rodolfo Oroz, Prensas de la Universidad de Chile, Santiago de Chile, 1941 , p. 276 ss.; el editor señala la correspondencia de las octavas 67 a 76 : "Poscia dicea piangendo: in voi servate/ questa dolente storia, amiche piante" - "Guardad, amigos árboles (decías)/ la no sabida historia de mi honesto/ amor"', que quizás pasará él por aquí, etc.-Antonio de GapMany, Filosofia de la eloquencia, Imprenta de D. Antonio de Sancha, Madrid, 1777, p. 117.

${ }^{94}$ Francisco DE LA TORRE, ed. cit.: "Pastor, que lees en ésta y en aquella/ planta Fili y Damón..." (Soneto 10 , p. 49 y nota a 7: VARCHI, soneto CCC, "Pastor, che leggi in questa scorza e'n quella/ Filli scritto e Damon. .. '); " "Quando Filis podrá sin su querido/ Damón vivir ausente y apartada,/ la corriente del Tajo acelerada/ buscará su principio conocido"./ Leyendo aquesto escrito en un florido/ tronco de vn haya de vna vid cercada,/ Tirsis, perdida la color rosada,/ cayó llorando a tierra sin sentido"' (soneto 9, p. 48, y nota 
6 de p. 49: VARCHI, soneto CCCLX, “Quando Filli potrà senza Damone . . / tornerà indietro al fonte suo Mugnone. . ./ così scritto leggendo in un troncone..."). Zamora Vicente remite, para éstas como para otras imitaciones de Varchi, al conocido trabajo de Crawford; sobre la influencia del poeta italiano, pueden verse los artículos de Marcel Bataillon, "Benedetto Varchi et le cardinal de Burgos D. Francisco de Mendoza y Bobadilla", Les Lettres Romanes, 23 (1969), 3-62, y Francisco MárQUEZ VillanUEva en el homenaje a Dámaso Alonso.

95 Episodio justamente recordado en las tierras del poeta, particularmente en lo que cuenta de los desmanes de Orlando en el canto XXIII: el hecho va registrado, de Giulio Fer Rario (Storia ed analisi degli antichi romanzi di cavalleria e dei poemi romanzeschi d'Italia . ., Milano, 1828-1829, t. 3, p. 115), al diccionario de literatura de Garzanti. Citamos por la ed. de Pietro Papini, Sanzoni, Firenze, 1916.

96 Toda encuesta sobre la influencia de Ariosto en las letras españolas debe forzosamente partir de la tesis de Maxime Chevalier, L'Arioste en Espagne (1530-1650). Recherches sur l' influence du "Roland furieux", Institut d'Etudes Ibériques et Ibéro-Américains de l'Université de Bordeaux, 1966, aunque considero muy difícil que se pueda aportar gran cosa a este detallado estudio de las versiones y recreaciones de la materia ariostesca. Entre los episodios de su poema mayor, "une plus grande faveur est reservée à l'histoire d'Angélique et Médor" (p. 402 ss.; la conclusión, p. 406, reconsidera el apogeo del tema y su decadencia). Nos permitimos sin embargo dar aquí algunos de esos textos espigados en dispersas lecturas. - Romancero de Pedrode Padilla (1583), reed. de la Sociedad de Bibliófilos Españoles, Madrid, 1880, romance 38, pp. 323 y 326: "y en qualquier árbol sombrío,/ después de haber descansado,/ con la punta de un cuchillo/ dexaua en él dibuxado/ su nombre con varios ñudos,/ y el de Angélica enlaçando. . . / Y leuantando los ojos,/ en mil partes ha halla$\mathrm{do} /$ junto con el de Medoro/ de Angélica el nombre amado. . ./ hizo pedaços la piedra/ sobre que estaua cortado,/ cortó los árboles todos/ que allí ninguno ha dexado". - LUCAS RODRÍGUEz, Romancero historiado con mucha variedad de glosas y sonetos y al fin una floresta pastoril y cantos pastoriles, Alcalá de Henares, 1585, reimpreso en el t. 10 de la Colección de libros españoles raros o curiosos, Madrid, 1875, "Romance sexto", pp. 112-115: "Suspenso y embebecido,/ con celoso sobresalto,/ el fiero conde de Brava/ tristemente se ha hallado/ en un prado y sitio umbroso/ al grueso tronco de un árbol,/ porque vido en la corteza/ todo su mal estampado,/ de cuya triste escultura/ aquesto entendió el cuitado:/ "Medoro, el más venturoso..../ y maldiciendo su hado/ a la espesura se torna,/ derecho se viene al árbol,/ y con un ansia rabiosa/ a Durindana ha sacado,/ y donde está la escriptura/ encamina el fuerte brazo;/ hiende, corta, raja y parte,/ en mil piezas lo ha tornado. .." (también en $B A E$, t. 10, núm 416, p. 272). -"Romance de Angélica y Medoro", en Fuentes..., t. 11 , f. 84 vo ss.: "Estas palabras de fuego/ escritas con una daga/ en el mármol de vna puerta/ el conde Orlando miraua"; y también t. 3, f. $155 \mathrm{v}^{\circ}-156$ : "lo que no alcançan Orlandos/ rompiendo robles y enzinas,/ vnos umildes medoros/ huyendo se lo conquistan." (Véase $B A E$, t. 10, 271, núm. 413, "Romance anónimo de Angélica y Medoro. De un códice del siglo XVI"'). Los ecos de Ariosto en el Quijote han sido señalados por Rodríguez Marín, I, xiii: "Nadie las mueva/ que estar no pueda con Roldán a prueba"' (t. 1, p. 298 de la ed. de Clási- 
eos Castellanos; la nota a la línea 20 cita parte del canto XXIV del Orlando: "Scrive nel verde ceppo in breve carme:/ "Armadura d'Orlando Paladino",/ come volesse dir: "Nessun la mova/ che star non possa con Orlando a provas": fin de la Primera parte (t. 4, p. 332): "Forse altro canterà con miglior plettro", y nota a la 1.14: "Es un verso de Ariosto, Orlando furioso, canto XXX, estancia 16", verso retomado, con el que le precede, en el cap. 1 de la Segunda parte (t. 5, p. 48 y nota a la 1.13); nueva mención, en boca de Don Quijote ("grabaremos en los árboles lo que en el trofeo de las armas de Roldán estaba escrito") en el cap. lxvi (t. 8, p. 211; la nota remite al cap. xiii de la Primera Parte. En la ed. postrera y póstuma del Quijote, Rodríguez Marín comenta las palabras arriba citadas del bachiller Sansón Carrasco (" . . y no dejemos árbol...") con unos versos de "Bernardo Tasso, en una de sus odas amorosas", que rezan: "Se non è tronco o ramo/ vostro, doue non sia/ impresso il nome de la Donna mia..." (t. 8, p. 244, nota a la linea 7). MAXIME ChEVALIER dedica a la influencia de Ariosto en Cervantes un nutrido capítulo (op. cit., pp. 439-491). - Baste un solo ejemplo de comedia: "A mi estado me parto,/ y vengaré en los sauces, / cual Orlando segundo,/ el agravio que me haces" (Guillén de Castro, Pagar en propia moneda, t. 1 de la ed. académica de sus Obras, p. 97). - "En un pastoral albergue"' (Góngora, Obras, ed. FoulchéDelbosc, t. 1, pp. 227-228, en $B A E$, t. 10, núm. 411, p. 271) inspira el octavo "Romance en que sigue al de Don Luis de Góngora de Angélica" de LóPEZ De Zárate, pp. 342-343 de la ed. cit. de Simón Díaz ("Probó en los robles las fuerÇas, / en las rocas el furor..."'; recuérdese todavía el popular "Dejad los libros ahora... (citamos por el Romancero general, ed. González Palencia, t. 1, p. 484, núm. 719): "Y vos, tronco, a quien abraça/ la mas luxuriosa vid,/ que este lagrimoso valle/ ha sabido producir,/ vivid en sabrosos años,/ en dulces treguas vivid/ siempre juntos a pesar/ de algun necio Paladin". La descendencia literaria de "En un pastoral albergue" ha sido estudiada por J. B. AvALLE ARCE, "Tirso y el romance de Angélica y Medoro", NRFH, 2 (1948), 275-281, estudio completado por MAXIMe ChEvalier en las pp. 425-426 de su libro, donde considera también la comedia anónima del mismo título (p. 431). Angélica y Medoro van citados en el Libro de diferentes y varias poesias, ms. 3913 (CEJAdOR, La verdadera... t. 8, 302, núm. 2966). La presencia de Ariosto en Lope es, quizás, la más dilatada. En Angélica en el Catay (María Rosa Lida llamó mi atención sobre esta pieza) es ella quien ruega: "Escribe aquí, por tu vida,/ alguna cosa, mi bien...' y a quien Medoro responde con medida (mal medida) cortesanía: "Demás que como se mira/ crecer en tan buena pieza/ la letra con la corteza,/ crecerá más la mentira" (Obras, ed. Real Academia Española, Madrid, 1902, t. 13, o. 434). Lope lo recordará en su égloga "Amarilis": "Estos olmos dirán, cuya corteza/ hoy crece con el nombre de Medoro"' (BAE, t. 38, p. 326), y transporta la escena a la eseena en La buena guarda: "los árboles de Alcides./ Mas, pues papel me ofrecen,/ libros serán del bien, que me enloquecen./ -Pues ¿qué intentas en ellos,/ dulce esposo del alma que te adora?/ - Fiar mi gloria dellos,/ porque me vino a la memoria agora/ lo que escribió Medoro/ cuando gozó de Angélica el tesoro./ - Detente, no lo escribas, / que no es Orlando el que leerlo puede...' (Obras escogidas, t. 2, p. 472). LoPE acepta "que el Ariosto me provoca", "Epístola a Juan de Arguijo", en La Gatomaquia, ed. Rodríguez Marín, p. 1ix, obra en la que cita a Ariosto y a sus personas no menos de ocho veces, en particular en la "Silva 
IV": "Así, desnudo Orlando, provocado/ de no menor injuria,/ cuando leyó los rótulos del Moro,/ que decían: "Amor, que sin decoro/ en la buena fortuna te gobiernas/ aquí gozó de Angélica Medoro»/ en el papel de las cortezas tiernas/ de aquellos olmos de su bien testigos,/ para el francés Orlando cabrahigos" (Parnaso de Sancha, t. 2, p. 259); y en La Dorotea "el Ariosto" y la "hermosura de Angélica" figuran tantas veces como los "libros de pastores", los "edilios piscatorios" y el "Damón de Virgilio" (ed. de Américo Castro, pp. 142, 148 y 163 para los dos primeros, y 10, 109 y 37 para los restantes). Entre las piezas recogidas en la Flor nueva publicada por Entrambasaguas, donde el nombre del Ariosto y el de su Orlando figuran en la "Elegía en la muerte del Licenciado Don Jerónimo de Villaizán", p. 179, un soneto bilingüe atestigua una vez más la fuerza del influjo italiano en la operación de escribir nombres en las cortezas y otras superficies: "Filippo vassi, e resta il nome impressol en las cortezas y disierta arena" ("Soneto hispano-italiano", p. 104). Tanto es así, que parece justicia que Juan Francisco Masdeu italianice a su turno el soneto de Baltasar de Escobar en loor de Herera: "y las ninfas del bosque.../ en cortezas de olivos entallando/ sus versos, qual si Apolo los digera" (pp. 58 y 59): "Le ninfe in sù la scorza de l'oliva/ scolpivanne ogni Nota fuggitiva,/ qual se il Nume cantasse de'poeti" (Poesias de veinte i dos autores españoles del siglo décimo sexto..., L. Perego Salvioni, Roma, 1786).

97 "Pronunciando estas voces, sacó su cuchillo y en la corteza de muchas encinas grabó estas palabras" (Vida del Perico del Campo, obra restituida a su idioma original por un buen español. Dala a luz el Abate Alcino. Madrid, por Ramón Ruiz, 1792, p. 63; el soneto, de las muchas encinas, pasa a la p. 64). - "Tu ufanía, el verdor tierno/ de tu corteza entallada/ de mil símbolos sencillos,/ todo en un punto acabara..." (MelÉndez Valdés, ed. Pedro Salinas, Espasa-Calpe, Madrid, p. 91). — "En la arena del río,/ en las verdes cortezas escribiré aquel nombre/ que hoy olvidar quisiera" (IRIARTE, "Anacreóntica V", Poesías, Espasa-Calpe, Madrid, p. 113). — “'Cuántas veces oíste el dulce nombre/ que mi amorosa boca repetía. . .!/ ¡Cuántas viste grabarle en la corteza/ del duro roble! ¡Cuántas..." (Quintana, "A Elmira”, Poesías, ed. Narciso Alonso Cortés, p. 192). - "Un nombre dulce, con buril grabado/ del sauce en la corteza" (Arolas, Poesias, Espasa-Calpe, Madrid, p. 49). - "Y entonces si al [sic] lauro/ poético ciño/ y allá en los vegetales/ del frondoso Pindo/ mi nombre entallado/ en troncos floridos/ veré por las ninfas/ del plácido río. . ." (Espronceda, Poesías, ed. Moreno Villa, t. 1, pp. 168-169). -Manuel Ma CHADO, "Gavarni", p. 175 de Apolo o p. 111 de las Obras completas de ambos hermanos. -Antonio Machado, "Campos de Soria, viii", p. 161 de las Obras, Séneca, México, 1940; cf. "a revelar secretos va a la aldea,/ que impide amor que en otro chopo lea", JáUREGUI, "Antídoto contra las Soledades, aplicado a su autor para defenderle de sí mismo", en JOSÉ JORDÁN DE URRIES Y Azara, Biografía y estudio crítico de Jáuregui, Sucesores de Rivadeneyra, Madrid, 1899 , p. 152. El texto de Machado reaparece, prosificado y amplificado, como epígrafe de una fotografía que ilustra, al parecer, el artículo de CoNCHA ZARDOYA, "Los caminos de Antonio Machado", $L T, 12$ (1964), frente a la p. 81: "Estos chopos del río, que acompañan con el sonido de sus hojas secas el son del agua, cuando el viento sopla, tienen en sus cortezas grabadas iniciales que son nombres de enamorados, cifras que son fechas"; la propia estudiosa ilustra el topos: "En los troncos inscribe/ el amor bellos nombres/ que no 
borra la lluvia./ ¡Cuántas veces brillaron/ en las plácidas tardes/ en que tú me besabas!" ("Hoy desdeño las flores", en la antología de poesía española moderna de José Luis Cano, Gredos, Madrid, 1972, p. 177). - "al modo que una saeta traspasa un corazón, según se ve en los emblemas de fidelidad perdurable...", etc. (PÉRez De AyAlA, El ombligo del mundo, en Obras completas, Renacimiento, Madrid, 1924, t. 17, p. 175). - "El Marqués, analfabeto [al Nigromante]: -El dómine me enseñó a leer los nombres de la Iglesia; y un escudero, a escribir con la punta de la daga de Doña Sol en la corteza de los árboles, pero vuestras escrituras del diablo, no las entiendo" (BARGA, pp. 150-151).

98 Véase este rápido ramillete: "En la corteza que cubre/ el tronco de aquel ciprés,/ he grabado con mis besos/ el nombre de una mujer' (Sevilla, Cancionero popular murciano, p. 239, núm. 970); "En la corteza de un árbol/ escribí tu nombre un día,/ y cuando quise borrarlo/ vide que ya no podía"' (ibid., p. 237, núm. 957); "En la corteza de un árbol/ su nombre escribió mi amor, $/$ y como estaba tan tierno,/ de la pena se secó" (Eusebio VASCO, op. cit., t. 2, p. 376, núm. 3394); "Tan hondo grabé tu nombre,/ que eché a perder un olivo;/ si me llegas a olvidar/ ¡qué lástima de arbolito!" (J. JIMÉNEZ DE ARAGÓN, p. 186, núm. 185); cf. " "Grabé tu nombre en un árbol»/ para tener tu recuerdo,/ al pasar de tantos años/ ni del árbol ya me acuerdo" (Coplas a escoplo, firmadas "Juancho", última página de La codorniz, Madrid y Barcelona, 29 de marzo de 1970).

${ }^{99}$ Un viejo etnógrafo asegura que las mujeres papúas “couvrent de dessins l'écorce des arbres, des feuilles"; el enamoradizo Huang persigue a dos volátiles bellezas hasta que ellas desaparecen: "Désolé de les avoir ainsi perdues, il prit un crayon et grava sur un arbre les vers suivants: [siguen cuatro versos]" (Contes du Yin et du Yang. Histoires et légendes de la Chine mistérieuse, textes recueillies et présentés para Claude Roy, trad. d'Hélène Chatelain, Tchou, Paris, 1969, p. 141); en su peregrinación, el bonzo Guioki "vio una día una gran morera, de la cual un gusano de seda había comido hasta la corteza. El bonzo se aproximó al árbol y, con gran sorpresa, leyó una poesía que el insecto había escrito sobre el tronco al roerlo: [sigue un corto poema religioso]" (Fukuyiro WaKatsuki, Tradiciones japonesas, Espasa-Calpe, p. 124); "Herbert en attendant va couper lui aussi, d'un coudrier qui pousse, la fameuse branche, la dépouiller, l'équarrir et y graver les deux noms entrelacés" (D'Annunzio, Le chevrefeuille, p. 7); “'También el moro Aarón, villano principal de la obra [el Titus Andronicus shakespeariano] gusta de expresarse por escrito: suele sacar de sus tumbas a los muertos, grabarles con una daga palabras provocativas en la espalda, "como en cortezas de árboles", y colocarlos así en la puerta de los amigos del difunto (V, 1)" (CURTIUS, op. cit., p. 468; el texto original, puesto en boca del propio ejecutor, reza: "And on their skins, as on the bark of trees,/ have with my knife carved in Roman letters, "Let not your sorrow die, though I am dead"', vv. 138-140, The tragedies of Shakespeare, Humphrey Milford-Oxford University Press, London [etc.], 1924, p. 281);" un arbre sur l'écorce duquel il [Cowley] avait gravé ses amours, vientil à mourir? C'est l'ardeur de ses flammes qui l'ont brûlé et consommé'" (ADDIsOn, en L'arte d'écrire, de Etiemble et Jeannine d'Etiemble, Seghers, Paris, 1970, p. 191); “ $D$ 'ailleurs, il avait envie de crier le nom de Rosamond à tous les vents et de le graver dans l'écorce des arbres" (Patricia Wentworth, Le 
point de non-retour, trad. Patrick Berthon, Seghers, Paris, 1980, p. 197); Paul, adolescente, "tira son couteau de sa poche et se mit à faire des intailles dans le tronc. Il voulait tracer un coeur enfermant la lettre $T_{\text {i }}$ [inicial de Thusvelde, su primer amor] et il tenait à una réussite parfaite, dût-il passer plusieurs jours à cette tâche" ("Juin", en Herman Hesse, Les frères du soleil, Calmann-Lévy, Paris, 1976, p. 151; el cuento data de 1904); “Elle [Ingrid] s'étonnait de voir des noms gravés sur le tronc des arbres" [riesgo que no correrá el hipotético lector de estas líneas] (Selma LagerlöfF, Le vieux manoir, Perrin et Cie., $\mathrm{Pa}$ ris, 1920 , p. 96).

100 ' Un myrthe je dédierai/ dessus les rives de Loyre,/ et sur l'écorce escriray/ ces quatre vers à ta gloire: Thenot sur ce bord icy, / a Vénus sacre et ordonnel ce myrthe, et luy donne aussy/ ces troupeaux et sa personne" (JOACHIM Du BELlAY, "A Venus", núm. XIV de sus Jeux rustiques, ed. V. - L. Saulnier, Giard-Droz, LilleGenève, 1947, pp. 23 y 198; la Introduction, pp. xxviii-xxix, que establece la genealogía Baqunides-Navagero-Ronsard para los Voeux, señala particularmente la deuda de Du Bellay con "Naugerius", es decir, con los Lusus póstumos de Andrea Navagero, atestiguando una vez más la influencia italiana en la propagación de este topos. - “Il n'y aura forest ou son nom sur l'escorce/ des chesnes les plus beaux ne soit inscrit à force,/ et qu'à l'entour du nom ne pendent mille fleurs/ et mille chapelets de diuerses couleurs" (Ronsard, Eglogue I), "Et alor les pasteurs à l'escorce des bois/ graueront leurs chansons" (id., Eglogue, "le veux soigneusement ce coudrier arrouser,/ et des chappeaux de fleurs sur les feuëilles poser,/ et auec vn poinçon ie veux dessus l'escorce/ engrauer de ton nom les six lettres à force,/ afin que les passants, en lisant Marion/ facent honneur à l'arbre entaille de ton nom" (id., 2. Amours), "Et sur deux cheuroteaux hier à toute force/ Auanson ie grauay auecques vn ponçon./ Les deux chesnes croistront, \& la nouuelle escorce/ portera iusquae au Ciel le nom d'Auanson" (id., Eclogue 4), "Et l'engrauay dedans le tige dur/ de ce coudrier: encor l'escorce verte/ y adioustant ces vers pleins de soucy/de l'engraueure apparoist entre-ouuerte,/ qu'encore vn coup ie vois redire icy" (id., Chant pastoral): todos los ejemplos citados de Ronsard se toman de la antología de Esprit Aubert, Les marguerites poetiques, tirées des plus fameux poètes françois, tant anciens que modernes, A Lyon, par Barthelémy Ancelin, 1613, pp. 222 y 381. Mayores noticias, para esta época, en la tesis de Alice Huluber, L'Églogue en France au $X V I^{e}$ siècle, Droz, Paris, 1938. - “. . il vit naistre à ses pieds vn grand Cyprez qui s'esleua tout à coup au milieu du theatre comme si quelque demo l'y fut venu porter. Il estoit si bien representé que la plus part le creurent estre naturel. Sur l'escorce du Cyprez se uoyoient escrites les mesmes paroles que les voix plaintives auoient chanté. Tancrede s'approcha en dansant, \& ayant leu les characteres, donna vn grand coup d'espée au Cyprez en cadence" (pp. 25-26 de la Relation du grand ballet du Roy..., lean Sara, Paris, 1619; no es menester señalar, una vez más, la influencia italiana). - La poesía de Evariste Parny, "Inscriptions sur un oranger" - quizás por influencia de las Madécases de Ravel- ha sido puesta en música por Louis Durey. - "Premier mai! l'amour gai, triste, brûlant, jaloux, / fait soupirer les bois, les nids, les fleurs, les Ioups: /l'arbre où j'ai, l'autre automne, écrit une dévise,/ la redit pour son compte et croit qu'il improvise" (VICTOR Hugo, "Premier mai", en Les contemplations, livre deuxième, L, Banville cita este fragmento en su Petit traité de poésie française, $2^{e}$ éd., rev. et corr., Librairie de l'Echo de 
la Sorbonne, Paris, 1871, p. 50). — "Il [le clerc boîteux] ajoute que les oeuvres de George Sand rapportent à ses héritiers de 40 à 50.000 francs par an, ce qui ne les empêche pas de laisser se perdre la propriété de Nohant et de faire couper des arbres historiques, des arbres sur l'écorce desquels, dit-il, George Sand avait certainement dû écrire quelque chose" (Jules RenARD, Journal, 24 mai 1891, NRF-Gallimard, Paris, 1952, p. 69). - "Suivant les murs, j'ai revu le Peyrou, le Peyrou n'est peuplé que de toi. Nous eussions dû, passants qui se remplacent, graver l'un après l'autre, tous trois [remitente, destinatario y su común amigo Rouart] nos noms sur le marbre ou l'écorce " (André Gide a Paul Valéry, p. 228 de su Correspondance); la subconciencia de esta ocupación hará eclosión en su última obra teatral, Le 13e arbre, de tan irisada trayectoria (solicitada por Pitoëff, será estrenada en otro teatro cuatro años más tarde; motivó la segunda y definitiva entrada de Léataud como crítico teatral de la $N R F$, y el propio Gide desaconsejó a Claude Mauriac asistir a su representación: cf. la edición del Théâtre complet de GIDE, Idées et Calendes, Neuchatel-Paris, 1948, t. 5, p. 175; MARIE DORMOY, en Le petit ouvrage inachevé de Paul Léautaud, Arléa, Paris, 1987, p. 58, y Claude Mauriac, Conversations avec André Gide, Albin Michel, Paris, 1951, p. 62; en la obra, un jardinero expone la diferente resistencia que las cortezas ofrecen a la inscripción, según sus especies, un poco como lo ha hecho, siglos atrás, Diego López comentando la "Égloga V" de Virgilio. - " . . . et encore/ les vignes de Lesbos et ses beaux oliviers/ où j'ai gravé mon nom de poète lyrique (VALERY Larbaud, A.O. Barnabooth, ses oeuvres completes. IL Europe, IX, Gallimard, Paris, 1948 , p. 97. - Edith, perseguida por Valérie que la cree un hombre, le dice que desea estar sola en compañía de un árbol: “ . . . aucun ami n'est plus fidèle, je vous assure, ni plus tendrement silencieux. Et si l'on peut se taire assez longtemps, on finit par comprendre son langage. - Valérie: Cela finit toujours par deux initiales de femme gravées sur son écorce. -Edith: Voilà une blessure que je ne lui infligirai jamais" (Francis DE MIOMANDRE, Les équivoques d'amour, Le bon plaisir, Toulouse, 1928, p. 84). - "Aux murs des fontaines, sur les arbres dont on avait enlevé l'écorce pour entrelacer des initiales, des dessins obscènes et des mots crapuleux publièrent la conduite de Lucien" (Marcel Arland, Monique, précédé de Terres étrangères, p. 60 del segundo relato)"'. - La Comtesse...(Après quelques pas indécis, elle s'arrête devant le plus gros arbre et se met à graver un "Nom" sur l'écorce). . . . qui m'eut dit - j'aurais dit non!-/ que sur cet arbre, un jour, je graverais un nom!/ Ah! la douce hantise qui nous pousse à mettre/ un petit nom, un seul, sur l'ecorce d'un hêtre?"' (Gaston Moreau, Sarabande, E. Cingla, Baugé, 1940, pp. 9 y 45). - "Michel Jobert: Par trente-six chemins. . lui donne l'occasion de graver sur l'écorce quelques petites phrases assassines"' (J. J., en L'Express, 28 de septiembre-4 de octubre de $198 . .$, p. 191).

101 "Le premier livre que je me rappelle avoir reçu était un Paul et Virginie à l'usage des enfants. Ce livre a laissé dans mon coeur une empreinte qui a grandi en moi, comme l'entaille faite à l'écorce d'un arbre"' (EDMOND DE Goncourt, en su Journal, t. 3, Fasquelle-Flammarion, Paris, 1956, p. 738, transcribe esta frase entre más: "Pensées cueillies dans un journal intime de jeune fille, sur des petits carnets couverts de notes crayonnées qu'on m'a confiés"). - "Mais qu'importe qu'un académicien, fût-il même ancien capitaine au long cours, vienne s'inscrire sur l'écorce du chêne séculaire: "Un Tel dit 
merde pour Victor Hugo", Dans peu de temps, très peu de temps, l'écorce aura repoussé, effaçant l'insulte puérile, et le chêne sera toujours debout"' (GABRIEL DE LAUTREC, Souvenirs des jours sans soucis, Éds. de la Tournelle, Paris, 1938, p. 20). “ Berthe: . . l'homme que j'aimais, que j' avais choisi depuis l'enfance, que j'ai attiré un soir sous le chêne où petite fille j'avais gravé son nom... Le nom grandissait chaque année!..." y "Je ne graverai plus de nom sur les chênes-lièges. .." (JEan Giraudoux, Ondine, Grasset, Paris, 1939, pp. 100-101 y 102). - "Gravez votre nom dans un arbre/ qui poussera jusqu'au nadir./ Un arbre vaut mieux que le marbre,/ car on y voit les noms grandir" (JEAN COCTEAU, "Pièce de circonstance", Vocabulaire, 1922, en Poésie, ed. cit., p. 360; texto puesto en música por Darius Milhaud con el título de Hommage à Jane Bathori, su intérprete preferida y mi inolvidable maestra). — "Claire Zahanassian: Alfred! le coeur que tu as gravé. Presque effacé. Avec nos deux noms, écartés l'un de l'autre. L'arbre a poussé. Son tronc et ses branches se sont épaissies, comme nous" (F. Dürrenmatt, La visite de la vieille dame, adaptation française de J. P Ponet, Flammarion, Paris, 1957, p. 35). - "Muchos nombres se leían/grabados en su corteza:/ cada nombre, una belleza/ lo escribió con un puñal;/ y la savia que subía/ por su fibra resinosa' iba saliendo copiosa/ por cada herida mortal . . . / cuando un hada enamorada, / vino, su sombra buscando,/ y al hallarle así expirando,/ le dijo: "No has de morir»./ Luego su dedo de rosa/ trazó en la corteza herida/ el dulce nombre de "Alida",/ e hizo al árbol retoñar./ Y el tierno retoño verde/ brotó junto del letrero/ que de todos fue el primero/ que hizo savia derramar" (José Luis Alfonso, "El árbol caído" en Cantos de un peregrino, A. Lainé-J. Harvard, Paris, 1863, pp. 65 y 66): relato que supera (y no es de extrañar, recurriendo como lo hace a la magia blanca) los encarecimientos similares del Siglo de Oro.

$102 \mathrm{El}$ cuadro de Reynolds muestra a Mrs. Lloyd de pie, en trance de agredir a mano armada una corteza. Árboles pintados son los dos que siguen: "A ces mots, il tourna le chevalet, et le duc put contempler le tableau. Il répresentait un grand arbre nu, aux branches duquel pendaient plusieurs douzaines d'hommes, dont beaucoup en complet état de putréfaction. Sur 1' écorce noirâtre de l'arbre, un coeur était gravé, avec ces signes: L.XI." (EwERs, "Le coeur des rois" en Dans l'épouvante, trad. Félix Gautier et Marc Henry, Paris, 1973, p. 49). "Au premier plan, sur l'écorce du gros arbre branchu, il a écrit mon nom" (CoLETTE, Le fanal, bleu: exergo o leyenda del "Paysage peint par Jean Marais et offert à Colette", pp. 242 y 243, núm. 429 del Album Colette, NRF-Gallimard, Paris, 1984).

103 Ejemplos de árboles anónimos: "Cual centinela solitario y triste/ un árbol en tu cima conocí./ Allí gravé [sic] mi nombre. ¿Qué lo hiciste?/ ¿Por qué no eres el mismo para mí? (AMELIA DeNIS DE ICAZA -1836-1911-, "Al Cerro Ancón"; citado por ElsIE Alvarado DE RICORD, "El sentimiento patriótico en la poesía panameña (a través de tres poemas representativos)", Lotería, nueva época, 1961, núm. 72, 39-44, en p. 43); "¿Aún guardas, árbol querido,/ la cifra ingeniosa y bella/ con que adornó mi adorada/ tu solitaria corteza?" (Heredia, La cifra, 1821; citado por JosÉ MARía CHACÓN Y CALvo en "Nueva vida de Heredia", $B B M P, 12,1930,315-358$, p. 328); "Recuerdo una plaza vieja/ no sé en qué triste ciudad./ Todavía, en algún tronco,/ nuestros nombres se leerán", y "'Oh, cifras del árbol/ preferido!", RafaEl Alberto ArRieta, "Canción ingenua" (1913) y "El retorno", en Fugacidad, Babel, Buenos Aires, 1921-1922, pp. 22 y 23; y "En un árbol del monte/ grabaré un corazón" (Raquel Sáenz, 
"La canción del bello atardecer", en Tirso Lorenzo, Antología de motivos poéticos, Cabaut, París, 1928, p. 59). - ¿Letras en un árbol? Sábelo Dios: "es un pulmón la encina en iniciales", Ney Irniob, "Juan Ramón Jiménez" en Guillermo ALFREDO COOK, Breve antología de poetas universitarios, Caracas, 1947, p. 83). - "lo escrito sobre una corteza nunca se borra", proclama (con mejor convicción que experiencia) Alejo CarPenTIER en Los pasos perdidos, México, 1953, p. 323; una semejante perduración busca ERnESTO SÁBATO: "Luego me levanté y me acerqué a aquel árbol en que varios años antes había grabado mis iniciales, cuando todavía era un niño: B. B. 1924"' (Sobre héroes y tumbas, Fabril Financiera, Buenos Aires, 1961, p. 373); la Evangelina de Olga OROzCO "En ningún corazón tatuó su nombre como en una corteza" (el poema, inédito cuando se reunían materiales para este trabajo, integró la vieja edición de Gulab y Aldabahor de Las muertes, y hoy puede leerse en la Antologia poética de su autora, Cultura Hispánica, Madrid, 1985, p. 40). - “Ah, qué mano remota, qué doliente,/ qué conmovido ser le hirió algún día,/ para dejar guardado en su corteza/ el nombre del amor./ $\mathrm{Y}$ ahora, qué silencio de piedra le recorre;/ qué mineral transformación ahonda/ el preferido adiós de aquellas vidas/ dispersas en el viento./ El tiempo detenido/ bajo su piel petrificada, tiembla:/ un alma se desprende/ de la callada tumba y lanza un nombre/ hacia la eternidad, que no responde" (HORACIO NúÑEz WEST, "El árbol milenario", en Poesía argentina actual, p. 246). - “¿Dónde escribiré tu nombre?/ Que los árboles me den su corteza más noble" (JosÉ IsAacson, Oda a la alegría, Hachette, Buenos Aires, 1965, p. 27). - Silvina OCAMPO se sirve de árboles no identificados ("Al cortar una rama del árbol, para ahuyentar la abeja, vi un nombre grabado en el tronco: María Gismondi"; " aproveché para decirle que había visto grabado en el tronco de un árbol de la estancia el nombre de María Gismondi... Insistí:". - QQuién habrá grabado el nombre de esa persona que yo quisiera conocer!": "El impostor", en Autobiografía de Irene, pp. 76 y 87; "Empezaba a grabar su nombre con tiza colorada en las estatuas... los nombres que había grabado en las estatuas, no los encontraba nunca la noche siguiente; por eso sacó su cortaplumas para grabarlos, como en los árboles, de una manera más segura, Viaje olvidado, Sur, Buenos Aires, 1937, pp. 128 y 130); pero precisa alguna vez su especie: "la luna vista a través de dos vidrios, las iniciales de su nombre grabadas por azar en el tronco de un cedro, la enloquecían de temor" (La furia y otros cuentos, Orión, Buenos Aires, 1976, p. 28). Otros árboles conocidos: "Ciprés/ donde grabamos antaño/ juramentos de los dos,/ testigo fue/ del triste adiós" (tango "La última cita"); "Fue en el roble,/ grabamos dos corazones./ El mío lo dejé allí,/ y el tuyo, después lo vi/ en otros que no eran robles", (Eduardo González Lanuza, Puñado de cantares, Mercatali, Buenos Aires, 1940, citado por Amado Alonso en su reseña, Sur, 1941, núm. 76, p. 123); JuAN RoDOLFO WILCOK, que se pintó "escribiendo en los troncos mi impaciencia", saca partido de los gruoos cultos al escribir "y porque aquí me amaste algún instante,/ nuestros dos nombres he dejado inscriptos/ en la corteza de estos eucaliptos,/ simbolizando un corazón constante" ("El alucinado" y "El aniversario" en Persecucióu de las musas menores, Buenos Aires, 1945, pp. 18 y 49).

104 "Fantasía del viaje" en Obras completas, F.C.E., México, t. 10, p. 68.

105 Luis L. Domínguez, “El ombú” en E. M. Barreda, Nuestro parnaso, J. L. Dasso, Buenos Aires, 1914, t. 1, p. 168.

${ }^{106}$ N. Granada, ¡Al campo! en LuIs Ordaz, Breve historia del teatro argentino, Eudeba, Buenos Aires, 1963, t. 3, p. 202. 
${ }^{107}$ Attilio Supparo, "Mi ombú", en García, Antología de poesía uruguaya, pp. 82-83.

108. Julıo Sánchez Gardel, Los mirasoles, Pan América, Buenos Aires, 1939, pp. 162 y 192.

${ }^{109}$ Martiniano Leguizamón, Recuerdos de la tierra, F. Lajouane, Buenos Aires, 1896, p. 240.

${ }^{110}$ Carlos Villafuerte, Voces y costumbres de Catamarca, Academia Argentina de Letras, Buenos Aires, 1961, t. 1, p. 380.

${ }^{111}$ Lisandro Alvarado, Glosarios del bajo español de Venezuela, Caracas, 1929 , p. 397 , s.v. puntilla, "cortaplumas".

${ }_{112}$ Luisa Mercedes Levinson, La casa de los Felipe, $2^{\mathrm{a}}$ ed., S. Rueda, Buenos Aires, 1969, p. 79.

${ }^{113}$ V. Martínez Cuitiño, El café de los inmortales, Kraft, Buenos Aires, 1954, p. 308. Cf. el estribillo de la pieza núm. 882 de Quevedo - p. 1308 de la edición de Blecua: "Lo escrito del cortezón viene a ser sentencia escrita". 114 "Idilio, o exequias al jabalí a quien partió el corazón con una bala en Aranjuez a seis de mayo [de 1625] la serenísima infanta doña María", ed. cit., núm. 206, p. 245; siguen nueve versos de 7 y de 11 sílabas.

115 "Égloga en que se describe el bosque de Aranjuez" en el Parnaso de Sancha, pp. 257 ss.

116 Incluso historias más complicadas (o menos difundidas), nos suministran tradiciones alejadas unas de otras: EDMOND DE GONCOURT poseía y describe "Une boîte à gateaux . . . dont le couvercle répresente le guerrier dessiné par Hokusaï en tête de son album intitulé Yéhon Sakigakë, "Les héros illustres", le guerrier écrivant sur un arbre l'avis qui doit amener la délivrance de son maître", Journal, ed. cit., t. 4, p. 684). El príncipe que conquista a La Hermosura del mundo, en la narración así denominada, va a buscar agua para ella, y comete la imprudencia de beber "agua del ojito", que "era un agua de encanto", quedándose "durmido". "La princesa, aquí onde estaba esperando a su marido con la agua que había ido a trai, se puso a escribir en un álamo con una navajita todos los trabajos que estaba pasando y esperando a su marido que ella pensaba que se lo habían comido las fieras y él estaba en el ojo durmido". El "armitaño" que podía, por su santidad, beber sin peligro de esa agua, "vino onde estaba el príncipe y lo desencantó y le dijo que juera al palacio del visrey, pero que juera primero onde había escrito su mujer abajo de un álamo", un año y siete meses antes, con lo que se produce el feliz reencuentro (Juan B. Rael, Cuentos españoles de Colorado y de Nuevo México. Spanish tales from Colorado and New Mexico, Stanford University Press, Stanford, s.a., t. 1 , p. 402 , núm. 168).

${ }_{117}$ Algunos ejemplos de guerra y de paz: "En suivant les marques faites sur les arbres, nous montâmes jusqu'à une position élevée, qui formait un saillant prononcé" y "Des marques faites sur les troncs indiquaient le chemin" (ERnest Junger, Premier journal parisien, éd. definitive revue par Henri Plard, Christian Bourgeois, Paris, 1980, p. 266 en Kurinskij, el 16 de diciembre de 1942, y pp. 272-273, cuatro días más tarde).- "Comme il rôdait, sans trop perdre oser perdre son cheval de vue, prenant soin de marquer l'écorce des arbres pour retrouver sa route, il aperçût de la lumière" ("II" es John Keats, héroe "d'une histoire féline", p. 147 del Journal d'un inconnu de JEAN CocTEAU). - "Le même jour, ordre était lancé à toutes les gendarmeries du Midi 
de rechercher sur les murs, sur les palissades, sur les pierres du chemin, voire sur le tronc des arbres, des signes plus ou moins semblables à ceux des remparts [trazados por los gitanos]" (Simenon, Les 13 coupables. Les 13 mystères. Les 13 énigmes, Librairie Arthème Fayard, Paris, 1958, p. 280). - "Au sortir du bois, nous avons remarqué sur un tronc de chêne un écriteau: Allée de la Providence. - Joli nom d'accueil!" (MARcel ARLAND, Lumière du soir, ed. cit., p. 134).

118 Andrew Marvell (1621-1678), Poems, Routledge, London, s.a., pp. 98-99, vv. 19-24 de "The garden": texto que debo, una vez más, a la generosidad de María Rosa Lida. La versión latina, "Hortus"' (pp. 173-175) es mucho más rica en nombres de mujeres y de vegetales: "Ah! quoties saevos vidi (quis credat?) amantes,/ sculpentes dominae potiori in cortice nomen!/ Nec puduit truncis inscribere vulnera sacris./ Ast ego, si vestras unquam temavero stirpes,/ nulla Naera, Chloe, Faustina, Corynna, legetur;/ in propio sed quaeque libro signabitur arbor./ O carae Platanus, Cyparissus, Populus, Ulmus!" (vv. 25-31, p. 174).

119 Martínez Padín, El bosque de Arminta, 1846, reed. en 1849; citado por Filgueira Valverde, p. 111 de La cantiga CIII. . ., Santiago de Compostela, 1936.

120 Jean Hugo, Le regard de la mémoire, Actes Sud: Hubert Nyssen, éd., 1983, p. 196. En sus memorias, la actriz Marie Marquet recuerda cómo, gracias a su relación con un importante dirigente, logró hacer pintar de blanco las protuberancias de los árboles que bordean las carreteras francesas, para aumentar su visibilidad durante las horas de la noche. - No sabría decidir en cuál de estos dos ámbitos introducir la proposición de RAFAel AlBerTI: "De cada amigo que me regale un frutal -ésa es la promesa- dejaremos su nombre grabado en el tronco como recuerdo agradecido" (La arboleda perdida, $\mathrm{Fa}$ bril Financiera, Buenos Aires, 1959, p. 330 y final).

${ }^{121}$ Desde Sannazaro, el uso parece tomar un carácter funerario: “Mentre Ergasto cantò la pietosa canzone, Fronimo... la scrisse in una verde corteccia di un faggio, \& quella di molte ghirlande investita appicò ad un albero, che sopra la bianca sepoltura stendeva i rami suoi" (p. 89 de la ed. veneciana de 1583; Gerhardt transcribe el párrafo en su p. 101, con alguna variante que procede de la ed. de Scherillo); Andrés Sanz Del Castillo describe una cruz, " $y$ al pie de ella un pedazo de bruñida corteza de una lisa haya, en que estaban impresos estos versos": tres octavas reales, que contienen un epitafio de diez versos formados por los 5-8 y 1-16 de las dos últimas (La mogiganga del gusto (1641) en la colección de Cotarelo y Mori, p. 89); “tenía [la suicida] la mano siniestra sobre un pedazo de corteza de un árbol, hecho en forma de una tarjeta o escudo. "... La ocasión que me ha puesto en la que me hallasteis, en esta corteza de árbol la hallaréis escrita..." y leyéndola vi que decía así: "Aquí murió quien viviera/ si no oyera:/ causa de su perdición/ en una conversación,/ fue oír lo que no debiera». Yo, que acababa de leer el epitafio..." (Novelas de Miguel Moreno y del Alférez Baltasar Mateo Velázquez, t. 4 de la Colección de Cotarelo y Mori, pp. 209 y 210-211). - Pero también en Sannazaro estas cortezas móviles se prestan a otros usos: uno de sus pastores puso "Una tabella per munusculo/ in su quel pin..." (p. 294 de la ed. de Scherillo, que no deja de referirse a las operaciones similares de Calpurnio). Lo mismo en Salvador Jacinto Polo de Medina: "una cartela de mármol que, pen- 
diente de un tronco, ocupaba este soneto... estos versos que, en un mármol impresos, fiaron a una rama de su tronco", álamo y naranjo de sus Academias del jardîn, pp. 110 y 112 de las Obras escogidas, ed. José María de Cossío (Los clásicos olvidados, t. 5, CIAP, Madrid, 1931); el japonesismo de Goncourt nos ofrece otro ejemplo más remoto, el de un kakemono "qui nous fit voir une Japonaise venant d'attacher une pièce de poésie à un cérisier en fleurs" (Journal, ed. cit., t. 4, p. 683). Como en algunos de los ejemplos dados, ambos procedimientos -inscripción directa y rótulo suspendido- podían ir juntos: el editor de Saavedra Fajardo trata de "la empresa que ofrecía pendiente el álamo, en cuya corteza aparecía grabado el soneto "Risa del monte"' llevaba por lema Nec te praesiveris extra (prefacio de la República literaria - si es suya - en la ed. de García de Diego, p. XLIV), reuniendo las indicaciones de las pp. 60-62: "Diárgenes [sic] . . . por la corteza de un álamo con la punta de un cuchillo moralizaba la claridad i pureza de sus aguas en este epigrama espanol...", pp. 60-61, y la tarjeta pendiente de un ramo del árbol en la página siguiente.

${ }^{122} B A E$, t. 35 , p. 294 , núm. 707.

${ }^{123}$ La primera cita sale de la Silva de varia lecion de Pero Mexía; y me excuso de sacarla de la ed. de Anveres, en la casa de Martin Nucio, 1603, que se dice "agora vltimamente emendada, y de la quarta parte añadida": al "platino" de la p. 506 puede agregarse la mención de "armas... de hierro y metal muy polidas y assi caladas" de p. 656 como ejemplo de las innumerables erratas sin enmendar. - La segunda procede del Discurso de las partes y calidades con que se forma un buen secretario..., compuesto por Juan Fernandes Abarca, Lisboa, P. Craesbeeck, 1618, f. $117 \mathrm{v}^{\circ}-118$. $-Y$ la tercera corresponde al clásico libro de Du MARsais sobre Des tropes. . , $3^{\mathrm{e}}$ éd. [sic], Paris, chez Paschal Prault, 1775, p. 82. Puede recordarse que Pagnol, al traducir la quinta égloga de Virgilio, así como reemplaza "fagus" por el fresno, reemplaza también directamente "cortice fagi" por el tecnicismo correspondiente: "ces vers qu'au tronc d'un frêne/ dans le tendre liber j'inscrivis en chantant"'.

${ }^{124}$ Obra inédita de Enrique Jardiel Poncela, Ahr, Barcelona, 1977, t. 2, p. 119.

125 Gengis Kan habría sido el inventor de esta novedad, que Marco Polo expone con admiración, según JACQUEs BaINVILle (Paroles hiperboliques, Eds. du Capitole, Paris, 1931, p. 64).

${ }^{126}$ Bernardino Baldi, "Egloga XVI”, vv. 12-15: “ed or, mentre procura/ da le scorze a metalli, indi alie carte/ fidar quei carmi onde sonar sovente/ fece le natíe valli e i patrii monti", ed. cit., p. 192.

127 Como menos eficaz aparece el procedimiento adoptado en el Collège Urbain IV, de Troyes, a principios de siglo: "Les bancs étroits et durs et les tables de bois épais portaient, profondément gravées au couteau, les traces durables de génerations successives, traces que les 50 centimes de "dégradations" débités à nos parents chaque trimestre ne parvenaient pas à effacer" (Louis Merlin, Jien ai vu des choses..., 1900-1939, Julliard, Paris, 1962, p. 54).

${ }^{128}$ A. Dumas, G. Lambert ou Le bagnard de l'Opéra, ed. cit., pp. 95-96.

129 Henri Béraud, La gerbe d'or, Eds. de France, Paris, 1928, p. 220.

${ }^{130}$ Paul Valéry a André Gide, Correspondance, ed. cit., p. 297.

131 André Maurois, Mémoires, Flammarion, Paris, 1970, p. 199.

132 Jean Guéhenno, Changer la vie, Grasset, Paris, 1965, p. 150. 
133 Paul Guth, Lettre ouverte aux futurs illétrés, Albin Michel, Paris, 1980, pp. 77-78.

134 Marie-Pierre Farkas, "Valentino mon amour", en revista Elle, núm. $1655,4^{\text {a }}$ semana de septiembre de 1977, pp. 62-63.

135 Bernard DuPriEz, Les procédés littéraires (Dictionnaire), $3^{\mathrm{e}}$ tirage, Union Générale d'Editions, Paris, 1981, s.v. épigramme, remarque 2.

${ }^{136}$ Paul Éluard, "Liberté" - obra para doble coro, música de Francis Poulenc- en Henri MORIER, Dictionnaire de poétique et de rhétorique, $2^{\mathrm{e}}$ éd., PUF, Paris, 1975, s.v. épiphore.

${ }^{137}$ José Mármol, Amalia, Garnier, Paris, s.a., t. 1, p. 185.

138 Eugenio Cambaceres, En la sangre (1887), J. C. Rovira, Buenos Aires, 1933, p. 32.

139 Manuel Gálvez, El mal metafísico, Tor, Buenos Aires, s.a., p. 112.

140 Baldomero Fernández Moreno, Vida. Memorias..., Kraft, Buenos Aires, 1957, p. 166.

${ }^{141}$ Alfredo Martínez Howard, Aire de gracia, ed. de amigos auspiciada por la Comisión Municipal de Cultura, Córdoba (Argentina), 1941; 3 (sin paginar).

142 Albert Acremant -marido de la autora, Germaine, y adaptador de su novela-Ces dames aux chapeaux verts, Guinaud Co., Boston etc., 1933, p. 67.

143 Miguel de Unamuno, "Salamanca", Poesias, Bilbao, 1907, pp. 29 ss.

144 Silvina Ocampo, "Fragmentos del libro invisible" en Autobiografía de Irene, Sudamericana, Buenos Aires, 1975, p. 134.

145 Marcel Bataillon, "Sur l'humanisme du docteur Laguna. Deux petits livres latins de 1543"', $R P h, 17$ (1963), 207-234.

${ }^{146}$ LuCio D'ARCANGelo, "La fortuna di Borges", QIA, 59-60 (19851986), 112-119, nota 20 de p. 118: un trozo de Sobre héroes y tumbas "é una versione involgarita, «esistenzialista" del finale di Don Segundo Sombra: "Y entonces Martín, contemplando la silueta gigantesca del camionero contra aquel cielo estrellado, mientras orinaban juntos, sintió que una paz purísima entraba por primera vez en su alma atormentada". Le sottolineature, ovviamente, sono nostre". Debo a la gentileza de mi amiga Bruna Cinti el haberme proporcionado este fascículo.

147 Nicolás Olivari, Cuadro sinóptico de mi existencia - "Diez horas, diez horas de almacén,/ diez horas, diez"-; en Pedro-Juan Vignale y CÉsar TIEMPO, Exposición de la actual poesía argentina, Minerva, Buenos Aires, p. 104. A parecido en La musa de la mala pata, Martín Fierro, Buenos Aires, 1926, p. 87; adoptamos las variantes de la antología. 